UNIVERSIDADE DE SÃO PAULO

FACULDADE DE CIENCIAS FARMACEUTICAS

Curso de Pós - Graduação em Fármaco e Medicamentos

Area de Produção e Controle Farmacêuticos

\title{
DETERMINACĀO ESPECTROFOTOMÉTRICA DO CLORIDRATO DE RANITIDINA EM MEDICAMENTOS
}

ELIANE MARIA DE ALMEIDÁ ORSINE

Dissertação para obtenção do grau de MESTRE

Orientador:

Prof. DI. JORGE LUIZ SEFERIN MARTINS

São Paulo

1992 
Aos meus pais Elias e Terezinha, aos meus irmãos Tadeu, Reinaldo, Jane e Delane, aos meus cunhados e aos meus sobrinhos, por tudo o que representam. 
Ao prof. Jorge Luiz Seferin Martins, pela orientação, amizade e compreensão. 
Ao prof. João Fernandes Magalhães, pelo grande estímulo.

À profá Lúcia Emy Teixeira dos Santos, pelo constante incentivo e pela valiosa amiza de.

Às amigas Lucimara, Lílian, Izabel, Cristina, Luciane e Luciene, pelo carinhoso convívio. 
À profá Érika R. M. Hackmann, pelo valioso apoio durante a reali zação deste trabalho e pelos constantes esclarecimentos.

À profá Maria Inês R. M. Santoro, pela confiança demonstrada por ocasião do encaminhamento de pedido de recursos para a conclusão deste trabalho e pelos valiosos esclarecimentos.

Ao prof. Massayoshi Yoshida, pela confiança demonstrada por ocasião do encaminhamento de pedido de recursos para a conclusão do presente trabalho.

Ao prof. Yukino Miyata, pelo carinho, pelas valiosas sugestões e pela amizade.

Ao prof. Wolfgang Seidel, pelos valiosos e pacientes esclareci mentos.

À farmacêutica Akimi Mori Honda, pela colaboração ao longo deste trabalho.

Aos companheiros: Márcia, Valéria, Hyun, Salete, Virgínia, EsteIa, Elton, Ana Maria, Lousã, Cristina, Marlene, Lucília e Vladi, pela colaboração e amizade.

À Íria R. da Silva, Márcia Vallim, Maria Lúcia F. Conceição e Re gina Rojas, pela amizade e pela atenção.

À Elisabete Claro de Souza Paiva, secretária do curso de Pós-grą duação em Fármaco e Medicamentos, pela atenção dispensada ao lon go deste trabalho.

À bibliotecária Moema Rodrigues dos Santos, pela cuidadosa revisão das referências bibliográficas. 
Ao Conselho Nacional de Desenvolvimento Científico e Tecnológico, CNPq, e à Fundação de Amparo à Pesquisa do Estado de São Paulo, FAPESP, pelos recursos financeiros que possibilitaram a realiza ção deste trabalho.

A todos que colaboraram direta ou indiretamente para a realização deste trabalho. 
ELIANE MARIA DE ALMEIDA ORSINE

DETERMINAÇAO ESPECTROFOTOMETRICA DO CLORIDRATO DE RANITIDINA EM MEDICAMENTOS

COMISSAO JULGADORA

DISSERTAÇÃO PARA OBTENÇÃO DO GRAU DE

MESTRE

Presidente e Orientador

2 Examinador

3 Examinador 
ÍNDICE

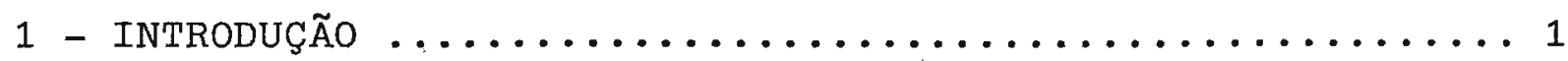

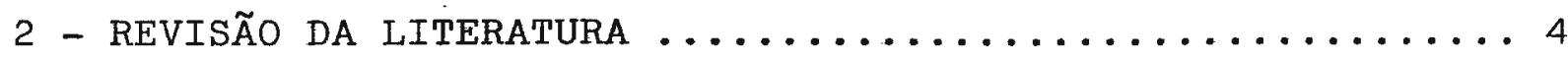

2.1 - GENERALIDADES $\ldots \ldots \ldots \ldots \ldots \ldots \ldots \ldots \ldots \ldots \ldots \ldots \ldots \ldots \ldots \ldots \ldots \ldots \ldots$

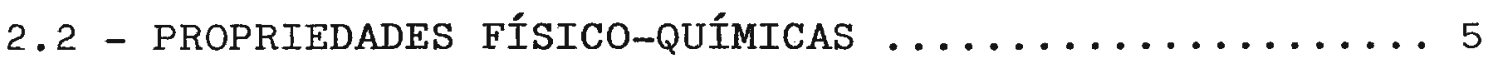

2.3 - METODOLOGIA ANALÍTICA PARA DETERMINAÇÃO

DA RANITIDINA $\ldots \ldots \ldots \ldots \ldots \ldots \ldots \ldots \ldots \ldots \ldots \ldots \ldots \ldots \ldots \ldots \ldots \ldots$

2.3 .1 - MÉTODOS DE IDENTIFICACÃ̃O ............. 5

2.3.1.1 - CROMATOGRAFIA EM CAMADA DELGADA ......... 5

2.3 .1 .2 - ESPECTROSCOPIA NO INFRAVERMELHO $\ldots \ldots \ldots \ldots \ldots 6$

2.3 .1 .3 - ESPECTROFOTOMETRIA NO ULTRAVIOLETA $\ldots \ldots \ldots \ldots 6$

2.3.2 - MÉTODOS DE DETERMINAÇÃO QUANTITATIVA

EM MEDICAMENTOS $\ldots \ldots \ldots \ldots \ldots \ldots \ldots \ldots \ldots \ldots \ldots \ldots \ldots \ldots \ldots$

2.3.2.1 - ESPECTROFOTOMETRIA UV/VIS ............ 7

2.3.2.2 - CROMATOGRAFIA LÍQUIDA DE ALTA EFI-

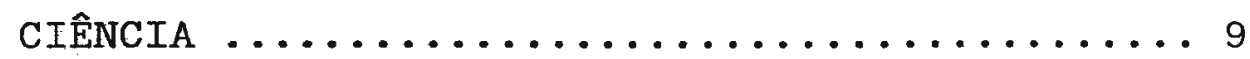

2.3 .2 .3 - TITULAÇÃO EM MEIO NÃO AQUOSO ............ 9

2.3.2.4 - MÉTODOS ELETROQUÍMICOS ............... 9

2.3.2.4.1 - POLAROGRAFIA ..................... 9

2.3.2.4.2 - POTENCIOMETRIA .................... 11

2.3.4 - MÉTODOS DE DETERMINAÇÃO QUANTITATIVA

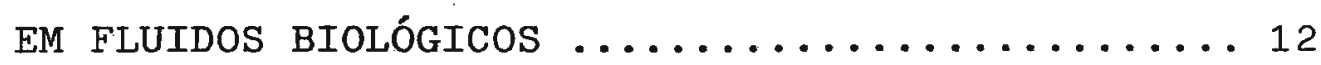

2.4 - UTILIZAÇÃO DO REATIVO MBTH EM ESPECTROFOTOMETRIA NO VISÍVEL $\ldots \ldots \ldots \ldots \ldots \ldots \ldots \ldots \ldots$

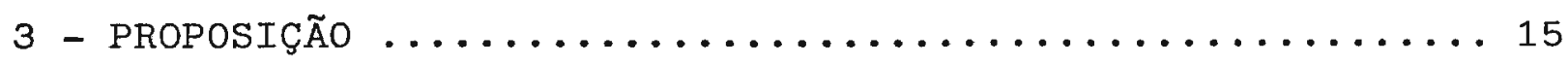

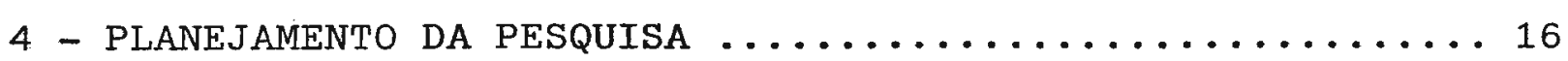

5 - PARTe EXPERIMENTAL $\ldots \ldots \ldots \ldots \ldots \ldots \ldots \ldots \ldots \ldots \ldots \ldots \ldots \ldots \ldots \ldots \ldots \ldots \ldots$

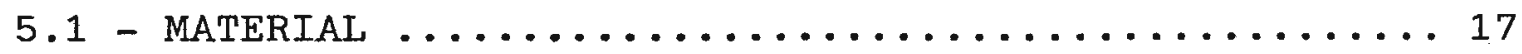

5.1 .1 - REAGENTES E SOLUÇÕES $\ldots \ldots \ldots \ldots \ldots \ldots \ldots \ldots \ldots \ldots \ldots \ldots \ldots \ldots \ldots$ 
5.1 .2 - FÁRMACO UTILIZADO COMO SUBSTÂNCIA

DE REFERÊNCIA ..................... 17

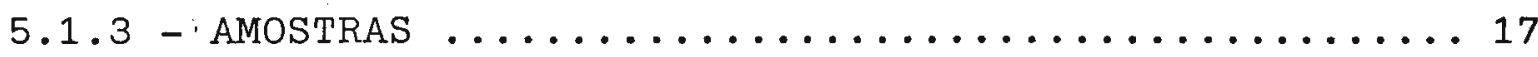

5.1 .4 - EQUIPAMENTOS .................... 19

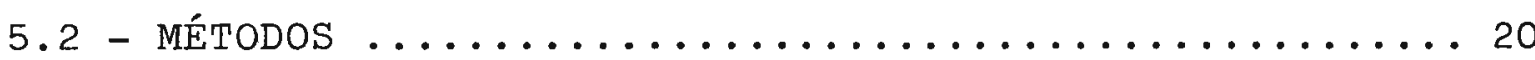

5.2 .1 - ESPECTROFOTOMETRIA NO ULTRAVIOLE-

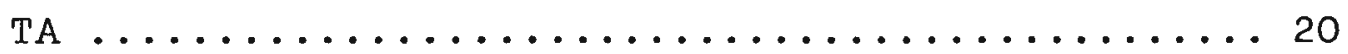

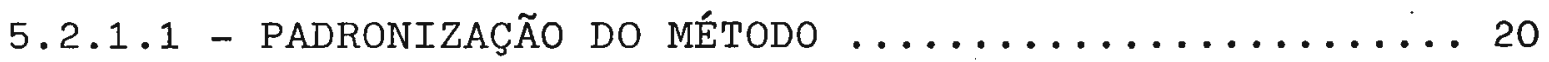

5.2 .1 .2 - APLICAÇÃO DO MÉTODO PADRONIZADO

A AMOSTRAS COMERCIAIS E SIMULA-

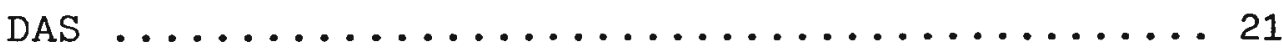

5.2 .1 .2 .1 - PESQUISA DE INTERFERÊNCIA A PAR-

TIR DOS EXCIPIENTES ................ 21

5.2 .1 .2 .2 - DETERMINAÇÃO DO TEOR DE CLORIDRA-

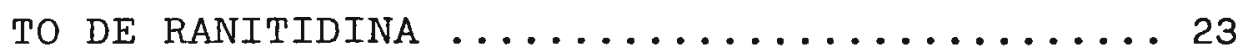

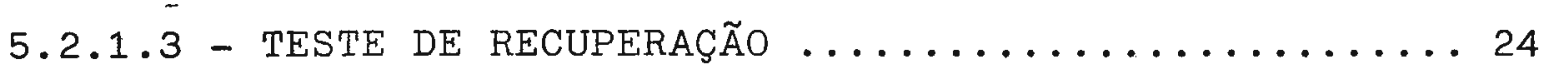

5.2 .2 - ESPECTROFOTOMETRIA NO VISÍVEL ............ 26

5.2 .2 .1 - PADRONIZAÇÃO DO MÉTODO ............... 26

5.2.2.1.A - ESTUDO DOS PRINCIPAIS FATORES QUE INFLUENCIAM A REAÇ̃O $\ldots \ldots \ldots \ldots \ldots \ldots \ldots$

5.2.2.1.A.1 - DETERMINAÇÃO DA CONCENTRAÇÃO Ó-

TIMA DE MBTH E CLORETO FÉRRICO ......... 26

5.2.2.1.A.2 - DETERMINAÇÃO DA CONCENTRAÇÃO DA

SOLUÇÃO DE HCl UTILIZADA COMO

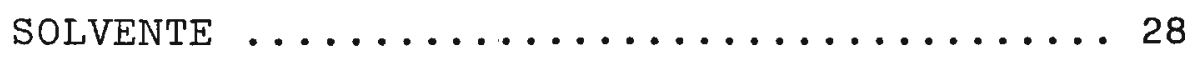

$5.2 .2 .1 . A .3$ - DETERMINAÇÃO DO TEMPO NECESSÁ-

RIO PARA A ESTABILIZAÇÃO DA RE-

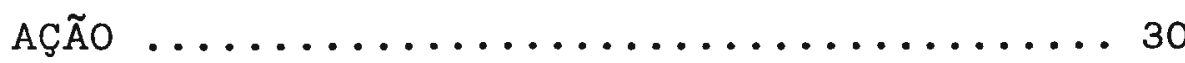

$5.2 .2 .1 . A .4$ - VERIFICAÇÃO DA INFLUÊNCIA DA. A_

DIÇÃO DE ÁGUA NO DESENVOLVIMEN-

TO DA REAÇÃO .......................... 31

5.2.2.1.A.5 - DETERMINAÇÃO DO TEMPO DE ESTABI

LIDADE DA REAÇÃO ................. 32 
5.2.2.1.A' - DETERMINAÇÃO DA RELAÇÃO ESTEQUIOMÉ TRICA ENTRE O CLORIDRATO DE RANITI DINA E $\bigcirc$ MBTH $\ldots \ldots \ldots \ldots \ldots \ldots \ldots \ldots \ldots \ldots \ldots \ldots \ldots \ldots \ldots \ldots$

5.2.2.1.B - DETERMINAÇÃO DO ESPECTRO DE ABSOR-

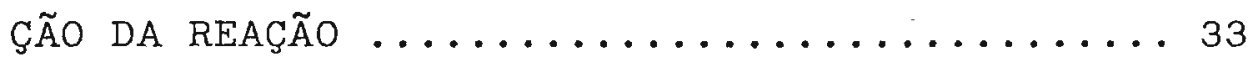

5.2.2.1.C - CONSTRUÇÃO DA CURVA DE RINGBOM ........... 35

5.2.2.1.D - CONSTRUÇÃO DA RETA DE CALIB́RAÇ̃̃O .......... 37

5.2.2.2 - APLICAÇÃO DO MÉTODO PADRONIZADO A AMOS TRAS COMERCIAIS E SIMULADAS ............ 37

5.2.2.2.1 - PESQUISA DE INTERFERÊNCIA A PARTIR DOS EXCIPIENTES ................... 37

5.2.2.2.2 - DETERMINAÇÃO DO TEOR DE CLORIDRATO DE RANITIDINA $\ldots \ldots \ldots \ldots \ldots \ldots \ldots \ldots \ldots \ldots \ldots \ldots \ldots$

5.2 .2 .3 - TESTE DE RECUPERAÇÃO $\ldots \ldots \ldots \ldots \ldots \ldots \ldots \ldots$

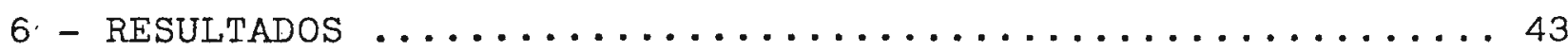

6.1 - ESPECTROFOTOMETRIA NO ULTRAVIOLETA ..........43

6.1 .1 - PADRONIZAÇ̃̃O DO MÉTODO $\ldots \ldots \ldots \ldots \ldots \ldots \ldots \ldots 43$

6.1 .2 - APLICAÇÃO DO MÉTODO PADRONIZADO A AMOS TRAS COMERCIAIS E SIMULADAS ...............4 43

6.1.2.1 - PESQUISA DE INTERFERÊNCIA A PARTIR DOS EXCIPIENTES .................... 43

6.1.2.2 - DETERMINAÇÃO DO TEOR DE CLORIDRATO DE RANITIDINA ........................ 44

6.1 .3 - TESTE DE RECUPERAÇÃO $\ldots \ldots \ldots \ldots \ldots \ldots \ldots \ldots \ldots 44$

6.2 - ESPECTROFOTOMETRIA NO VISÍVEL $\ldots \ldots \ldots \ldots \ldots \ldots \ldots \ldots \ldots \ldots \ldots \ldots \ldots \ldots \ldots$

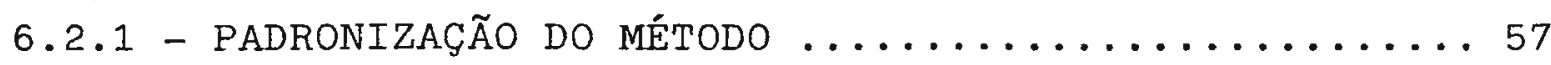

6.2 .2 - APLICAÇÃO DO MÉTODO PADRONIZADO A AMOSTRAS COMERCIAIS E SIMULADAS $\ldots \ldots \ldots \ldots \ldots \ldots \ldots$

6.2.2.1 - PESQUISA DE INTERFERÊNCIA A PARTIR. DOS EXCIPIENTES . .................... 58

6.2.2.2 - DETERMINAÇÃO DO TEOR DE CLORIDRATO DE RANITIDINA $\ldots \ldots \ldots \ldots \ldots \ldots \ldots \ldots \ldots \ldots \ldots \ldots \ldots \ldots \ldots \ldots \ldots$ 


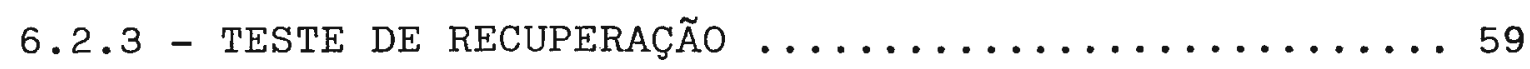

7 - ANÁlise estatística dos Resultados ................ 74

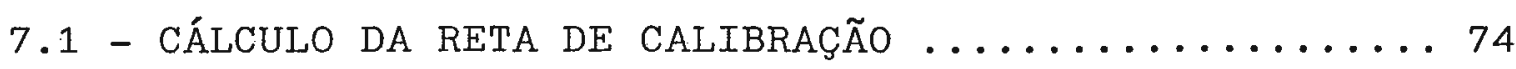

7.2 - CÁLCULO DO COEFICIENTE DE VARIAÇÃO - DETER MINAÇÃO DO CLORIDRATO DE RANITIDINA EM MEDICAMENTOS ......................... 78

7.3 - COMPARAÇ̃̃O DA EXATIDÃO E PRECISÃO DOS MÉTO DOS PROPOSTOS ........................ 82

8 - DISCUSSก̃O $\ldots \ldots \ldots \ldots \ldots \ldots \ldots \ldots \ldots \ldots \ldots \ldots \ldots \ldots \ldots \ldots \ldots \ldots \ldots \ldots \ldots$

8.1 - ESPECTROFOTOMETRIA NO ULTRAVIOLETA ........... 87

8.1.1 - ESCOLHA DO COMPRIMENTO DE ONDA DE LEITU-

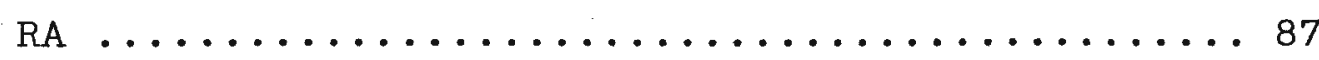

8.1 .2 - PESQUISA DE INTERFERÊNCIA A PARTIR DOS EXCIPIENTES $\ldots \ldots \ldots \ldots \ldots \ldots \ldots \ldots \ldots \ldots \ldots$

8.2 - ESPECTROFOTOMETRIA NO VISÍVEL ............. 89

8.2.1 - DETERMINAÇÃO DA CONCENTRAÇ̃̃O ÓTIMA DE MBTH E CLORETO FÉRRICO $\ldots \ldots \ldots \ldots \ldots \ldots \ldots \ldots$

8.2 .2 - INFLUÊNCIA DO SOLVENTTE $\ldots \ldots \ldots \ldots \ldots \ldots \ldots \ldots 91$

8.2.3 - TEMPO NECESSÁRIO PARA A ESTABILIZAÇ̃̃O DA REAÇ̃̃O $\ldots \ldots \ldots \ldots \ldots \ldots \ldots \ldots \ldots \ldots \ldots \ldots \ldots \ldots \ldots \ldots \ldots$

8.2 .4 - INFLUÊNCIA DA ADIÇÃO DE ÁGUA ............. 92

8.2 .5 - TEMPO DE ESTABILIDADE DA REACÃO $\ldots \ldots \ldots \ldots \ldots \ldots$

8.2.6 - ESPECTRO DE ABSORÇÃO DO PRODUTO COLORIDO

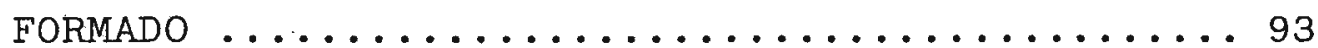

8.2.7 - MECANISMO E RELAĢ̃O ESTEQUIOMÉTRICA .......... 93

8.2.8 - PESQUISA DE INTERFÊNCIA A PARTIR DOS

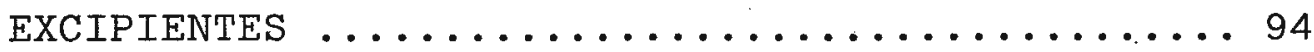

8.3 - CURVAS DE RINGBOM E RETAS DE CALIBRAÇÃo ......... 95

8.4 - APLICAÇÃO DOS MÉTODOS NA DETERMINAÇÃO DO TEOR DE CLORIDRATO DE RANITIDINA A AMOSTRAS COMERCIAIS E SIMULADAS $\ldots \ldots \ldots \ldots \ldots \ldots \ldots 96$ 
8.5 - COMPARAÇÃO DA EXATIDÃO E PRECISÃO DOS DOIS MÉTODOS ........................ 96

$9-$ COnchusões $\ldots \ldots \ldots \ldots \ldots \ldots \ldots \ldots \ldots \ldots \ldots \ldots \ldots$

10 - PERSPECtivas de trabalhos futuros $\ldots \ldots \ldots \ldots \ldots \ldots \ldots$

REFERÊNCIAS BIBLIOGRÁFICAS $\ldots \ldots \ldots \ldots \ldots \ldots \ldots \ldots \ldots \ldots \ldots \ldots \ldots \ldots \ldots \ldots \ldots \ldots$

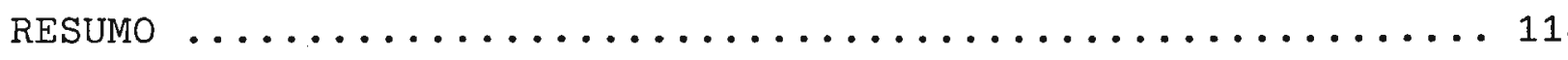

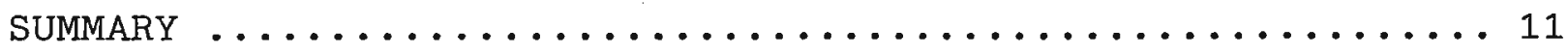


1 - INTRODUÇÃO

Os antagonistas dos receptores $\mathrm{H}_{2}$ da histamina figuram como importantes agentes para o controle da acidez gástrica e tratamento de úlceras pépticas.

o ácido gástrico é secretado pelas células parietais localizadas, principalmente, na porção superior do estômago e é estimulado por três substâncias endógenas: gastrina, acetilcolina e histamina. Gastrina e acetilcolina atuam na liberação da histamina, a qual age sobre os receptores $\mathrm{H}_{2}$ nas células parietais para estimular a secreção ácida (66).

Os bloqueadores $\mathrm{H}_{2}$ inibem a secreção ácida gástrica produzida pela histamina ou outros agonistas destes receptores de maneira competitiva. O grau da inibição induzida com doses terapêuticas equivale à concentração plasmática da droga ( 28 , 66 ).

- O desenvolvimento dos bloqueadores $\mathrm{H}_{2}$ teve início a partir da sintese da burimamida, através de uma modificação estrutural da molécula da histamina. Modificações estruturais da molécula da burimamida resultaram em outro fármaco, a metiamida, mais potente que o fármaco anterior. Entretanto, a ocorrência de granulocitopenia em cerca de $1 \%$ dos pacientes tratados com metia mida provocou a sua substituição pela cimetidina.

Todos esses compostos possuem estruturas com anel imidazólico, o que não ocorre nos compostos desenvolvidos mais recentemente, co mo a ranitidina, que possue um furano ou a famotidina e a nizati dina, que possuem um tiazol no lugar daquele anel $(28,41,89)$. 
A ranitidina foi desenvolvida na década de 70 (56), e introduzida no mercado em 1981 (34).

A ranitidina (I) corresponde, quimicamente, ao $\mathrm{N}-|2||| 5-\mid$ (dimetilamino)metil|-2-furanil|metil|tio|etil|-N'- metil-2-nitro-1,1-etenodiamino e é usada como cloridrato.

A fórmula molecular do cloridrato de ranitidina é $\mathrm{C}_{13} \mathrm{H}_{22} \mathrm{~N}_{4} \mathrm{O}_{3} \mathrm{~S}$. HCl e seu peso molecular é 350,87 (85).<smiles>CNC(=C[N+](=O)[O-])NCCCc1ccc(CN(C)C)o1</smiles>

(I)

Como princípio ativo único, o cloridrato de ranitidina é comercializado no Brasil sob as formas farmacêuticas comprimido, solução injetável e xarope (16).

A tabela 1.1 mostra os medicamentos comercializados no Brasil, contendo cloridrato de ranitidina. 
Tabela 1.1 - Medicamentos comercializados no Brasil contendo cloridrato de ranitidina

Laboratório

Forma farmacêutica-Apresentação-Composição

- Comprimido - Caixas com 10 e 20 unidades $150 \mathrm{mg} / \mathrm{comp}$.

- Caixas com 8 unidades -

A 300mg/comp.

- Solução injetável - Caixas com 5 ampolas $50 \mathrm{mg} / 2 \mathrm{~mL}^{*}$

- Xarope - Frascos com $120 \mathrm{~mL}-150 \mathrm{mg} / 10 \mathrm{~mL}{ }^{*}$

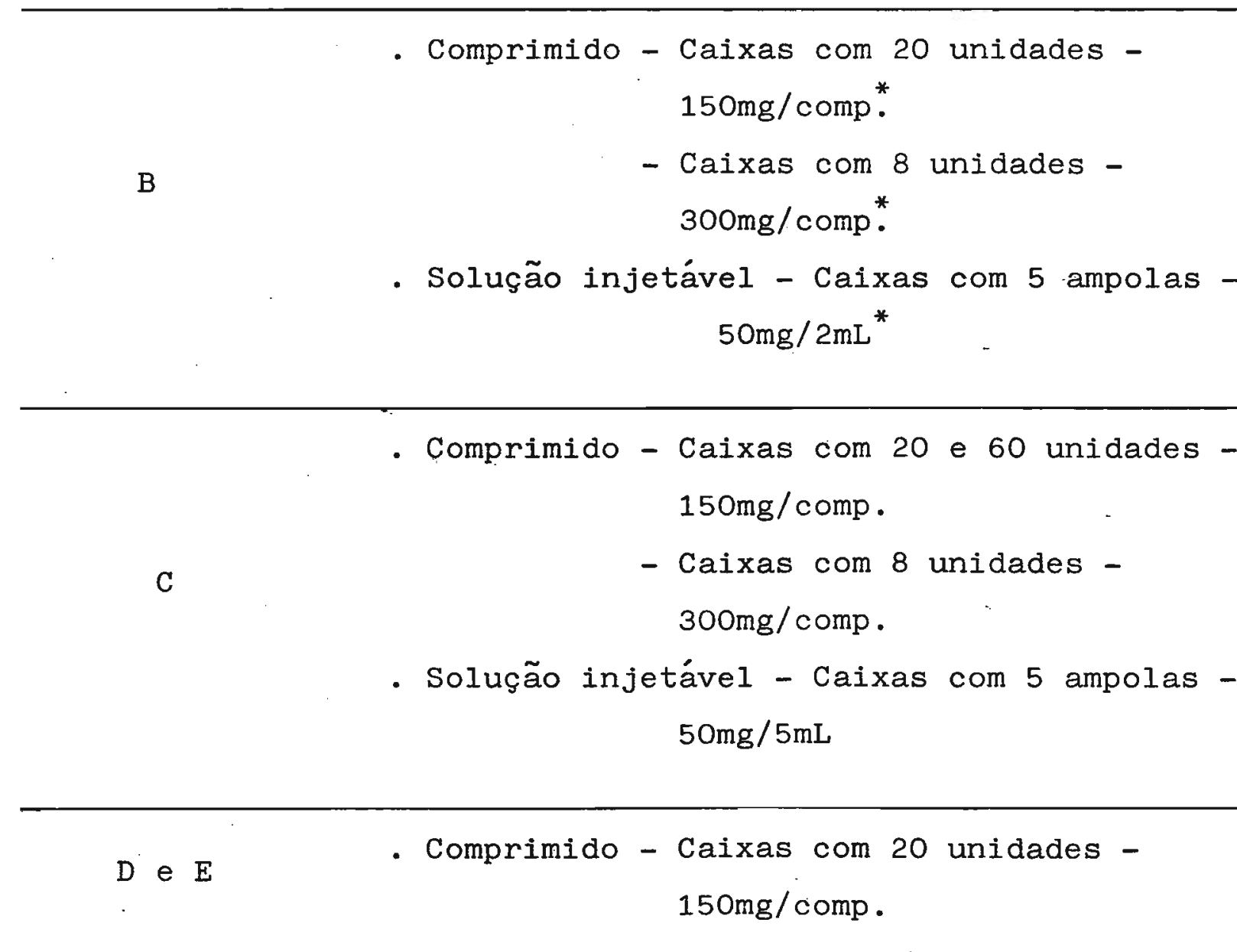

Expresso em ranitidina base.

Dados: Dicionário de especialidades farmacêuticas 91/92 (16). 
2 - REVISÃo DA LITERATURA

\section{1 - GENERALIDADES}

A ranitidina é um potente inibidor da produção do ácido gástrico basal e da secreção ácida gástrica induzida por uma série de estímulos fisiológicos (29), dentre eles a histami na, a pentagästrina e a acetilcolina (12).

É efetiva para o tratamento de úlceras gástricas e duodenais; é recomendada no tratamento da esofagite de refluxo e das condições hipersecretórias patológicas, como a sindrome de Zollinger-Ellison; tem sido utilizada na prevenção de úlceras de stress e hemorragia do trato gastrointestinal, além da sín drome de aspiração ácida (pneumonite de aspiração), que pode ocọ rer durante cirurgias com anestesia geral (17, 29, 44).

A ranitidina é rapidamente absorvida após administracão oral ou intravenosa. As concentrações plasmáticas atingem o máximo em torno de duas horas após administração oral e não são influenciadas pelos alimentos; porém, a absorção decresçe quando a administração é feita junto com antiácidos $(29,66)$.

- fármaco tem meia-vida de duas horas e é fracamente ligado a proteínas plasmáticas (em torno de 15\%) (17, 29).

Uma pequena proporção de ranitidina é metabolizada no fígado a N-óxido de ranitidina, S-óxido de ranitidina e desmetilranitidina, farmacologicamente inativos, mas a maior parte (cerca de $30 \%$ da dose administrada oralmente e de 68 a $79 \%$ de uma dose intravenosa) é excretada na forma inalterada na urina (17, 29, 44, 66 ).

Os efeitos adversọ são mínimos e pouco frequentes, com incidência menor que $3 \%$ e incluem dor de cabeça, erupções cutâneas, náuseas, constipação, vertigens e dores abdominais (17, 66 ). 
Doses usuais de ranitidina só raramente produzem efeitos mais sérios como confusão mental, ginecomastia, hiperprolactinemia, disfunção sexual, bradicardia ou hepatite ( 17 , $29,66)$.

O fármaco é contra-indicado em portadores de discra sias sanguíneas, bem como, pela impossibilidade de experimentação clínica, para mulheres grávidas (89).

2.2 - PROPRIEDADES FÍSICO-QUÍMICAS

Ranitidina é comercializada apenas como cloridrato, - qual é bastante solúvel em água e ácido acético, solúvel em metanol, um pouco menos solúvel em etanol, muito fracamente solúvel em acetato de etila e isopropanol, e insolúvel em dioxano e clorofórmio. Apresenta-se sob a forma de um pó amarelado, com leve odor de mercaptano $(34,35)$.

A ranitidina base e o cloridrato têm faixa de fusão de $69-70^{\circ} \mathrm{C}$ e $133-134^{\circ} \mathrm{C}$, respectivamente (45).

2.3 - METODOLOGIA ANALÍTICA PARA DETERMINAÇÃO DA RANITIDINA

2.3.1 - MÉTODOS DE IDENTIFICAÇÃO

2.3.1.1 - CROMATOGRAFIA EM CAMADA DELGADA (CCD)

Um sistema cromatográfico foi desenvolvido para o cloridrato de ranitidina, utilizando-se acetato de etila - meta nol - dietilamina $(3: 3: 1)$ como fase móvel e sílica gel como fase estacionária. A localização do fármaco, após desenvolvimento do cromatograma, através de lâmpada ultravioleta e exposição a vapores de iodo constituíram o sistema de revelação (35). 
A Farmacopéia Americana XXII- (85) recomenda a CCD pa ra a identificação do fármaco em injetáveis e comprimidos. A fase estacionária e os sistemas eluente e de detecção indicados no método são sílica gel, acetato de etila - álcool isopropílico hidróxido de amônio - água (25:15:5:1), e exposição a vapores de iodo, respectivamente.

2.3.1.2 - ESPECTROSCOPIA NO INFRAVERMELHO (IV)

O cloridrato de ranitidina foi identificado por espectroscopia no infravermelho com a utilização de pastilhas de brometo de potássio no preparo da amostra (35).

A espectroscopia no IV é un dos métodos recomendados pela Farmacopéia Americana XXII para a identificação do fármaco na matéria-prima. A análise é feita em uma dispersão do cloridra to de ranitidina em óleo mineral (85).

\subsubsection{3 - ESPECTROFOTOMETRIA NO ULTRAVIOLETA (UV)}

A Farmacopéia Americana XXII recomenda a espectrofotometria no UV como um dos métodos de identificação do cloridrato de ranitidina na matéria-prima, a 229 e $315 \mathrm{~nm}$.

Entre outros métodos de identificação do fármaco podem ser citados: Ressonância magnética nuclear (protônica $\mathrm{e}^{13} \mathrm{C}$ ) espectrometria de massas (34), cromatografia líquida de alta efí ciência e reação para cloretos ( 85 ). 
2.3.2 - MÉTODOS DE DETERMINAÇÃO QUANTITATIVA EM MEDICAMENTOS

2.3.2.1 - ESPECTROFOTOMETRIA UV/VIS

Recomendou-se a determinação do cloridrato de ranitidina na matéria-prima e em comprimidos, através da medida da absorbância a $313 \mathrm{~nm}$, de soluções contendo $10 \mu \mathrm{g} / \mathrm{mL}$, utilizando-se água destilada como solvente (35).

O fármaco foi determinado em comprimidos, a 314 e 220 $\mathrm{nm}$, utilizando-se tampão fosfato e $\mathrm{HCl} 0,1$ M como solventes, respectivamente (10).

Vários métodos espectrofotométricos no visivel foram propostos para a determinação do cloridrato de ranitidina em medi camentos $(23,26,31,52,53,58,60,61,63,65,69)$.

Os principais reagentes utilizados nestes métodos e os respectivos comprimentos de onda de leitura estão relacionados na tabela 2.1 .

Tabela 2.1 - Métodos espectrofotométricos no visível.

2,6-dicloroquinona

clorimida

520 23

Reinekato de amônio

a $2 \%$ em água destilada

525 26 
Tabela 2.1 - (Cont.)

Reagentes

Comprimento de onda

( $\mathrm{nm}$ )

Referência

507

31

Reagente de Van Urk

(4-dimetilaminobenzal-

deído a $1 \%$ em $\mathrm{HCl}$ conc.

-etanol $1: 1$ )

Cloridrato de fenilhi-

drazina em $\mathrm{H}_{2} \mathrm{SO}_{4}$ a $80 \%$

440

53

P-dimetilaminocinamal-

deído em meio ácido

500

60

Cloridrato de MBTH e

cloreto férrico, ambos

a $0,20 \%$ em $\mathrm{HCl} 0,1 \mathrm{M}$

615

61

Rosa Bengala a 1,0\% em-

água destilada

550

65

Reagente de Folin-Cio-

calteau e $\mathrm{Na}_{2} \mathrm{CO}_{3}$ a $20 \%$

765

63

Azul de bromotimol

409 e $415-420$

52,69

Púrpura de bromocresol

$415-420$

69

Azul de bromofenol

414 e $415-420$

58,69

Verde de bromocresol

417 e $415-420$

58,69 


\subsubsection{2 - CROMATOGRAFIA LÍQUIDA DE ALTA EFICIÊNCIA (CLAE)}

A Farmacopéia Americana XXII preconiza a utilização da CLAE para determinação do cloridrato de ranitidina na matéria -prima, em comprimidos e injetáveis. A fase móvel recomendada é composta por metanol-solução de acetato de amônio 0,1 $\underline{M}$ (85:15), e a coluna é $\mathrm{RP}_{18}$, de 4,6 mm x 20-30 cm. A deteção é feita a $322 \mathrm{~nm}(85)$.

Vários métodos de CLAE foran propostos para determinação do cloridrato de ranitidina (em estudos de estabilidade) na matéria-prima (4), em comprimidos (4,13), em injetáveis (13) e em misturas com fluidos de infusão (25, 40), con fluidos de in fusão associados a outros medicamentos (24), com soluções para nutrição parenteral (6) e com soluções para nutrição parenteral total $(7,86,87)$.

A tabela 2.2 reúne as colunas, fases móveis e comprị mentos de onda de detecção utilizados nestes métodos.

2.3.2.3 - TITULAÇÃO EM MEIO NÃO AQUOSO -

o cloridrato de ranitidina foi determinado na maté ria-prima através de titulação em meio não aquoso, utilizando-se ácido acético glacial como solvente, ácido perclórico 0,1 N como titulante e vermelho de quinaldina como indicador. Os teores encontrados, para uma série de determinações, variaram de $98,52 \%$ a $100,92 \%(32)$.

2.3.2.4 - MÉTODOS ELETROQUÍMICOS

2.3.2.4.1 - POLAROGRAFIA

o comportamento eletroquímico da ranitidina, em dife- 
Tabela 2.2 - Métodos de CLAE para a determinação da ranitidina em medicamentos.

\begin{tabular}{|c|c|c|c|}
\hline Coluna & Fase móvel & $\begin{array}{c}\text { Det. UV } \\
(\mathrm{nm})\end{array}$ & Referência \\
\hline \multirow{3}{*}{$\begin{array}{l}\text { Spherisorb } \\
\text { CN }\end{array}$} & Acetonitrila - tampão & & \\
\hline & fosfato $\mathrm{pH} 5,0$ & & \\
\hline & $(30: 70)$ & 228 & 4 \\
\hline \multirow{3}{*}{$\begin{array}{c}\mu \text {-Bondapak } \\
\mathrm{C}_{18}\end{array}$} & Acetonitrila/fosfato & & \\
\hline & $\begin{array}{l}\text { de potássio - ácido } \\
\text { pentano sulfônico }\end{array}$ & & \\
\hline & $(8: 92)$ pH 6,1 & 228 & 6 \\
\hline \multirow{4}{*}{$\begin{array}{l}\mathrm{HS}-3 \\
\mathrm{C}_{18}\end{array}$} & Água - acetonitrila & & \\
\hline & - hidróxido de amônio & & \\
\hline & a $5 \%$ em álcool isopro & & \\
\hline & pílico $(83: 10: 7)$ & 228 & 7 \\
\hline Partisil - & Metanol - acetato de & & \\
\hline ODS 1 & amônio $0,1 \underline{\mathrm{M}}(85: 15)$ & 322 & 24,25 \\
\hline \multirow{3}{*}{$\begin{array}{l}\text { Nova Pak } \\
\mathrm{C}_{18}\end{array}$} & Fosfato de potássio & & \\
\hline & $\begin{array}{l}0,1 \underline{\mathrm{M}} \text { - ácido pentano } \\
\text { sulfônico } 5 \underline{\mathrm{mM}} \text { - ace- } \\
\text { tonitrila - água }\end{array}$ & & \\
\hline & $(18,4: *: 12: *)$ pH 6,3 & 228 & 40 \\
\hline \multirow[t]{2}{*}{$\mathrm{RP} \quad \mathrm{C}-2$} & Acetonitrila - tampão & & \\
\hline & fosfato $(34: 66) \mathrm{pH} 6,8$ & 235 & 86 \\
\hline Spherisorb & Tampão fosfato - metanol & & \\
\hline ODS 1 & $(24: 76) \mathrm{pH} 6,0$ & 228 & 87 \\
\hline
\end{tabular}


rentes suportes eletrolíticos, foi-estudado por polarografia $(71,83)$ e através da redução do grupo nitroeteno, o fármaco foi determinado na matéria-prima por polarografia de corrente direta e de pulso diferencial, em tampão acetato pH 5,5. Obteve-se linearidade nas faixas de concentração de $2,4-4,9 \times 10^{-4}$ M e 2,5 $\times 10^{-7}-2,05 \times 10^{-5} \underline{\mathrm{M}}$, respectivamente (15).

Ranitidina foi determinada por polarografia, em com primidos e injetáveis, utilizando-se tampão de McIlvaine pH 3,0 . o limite de detecção foi $7 \times 10^{-4} \underline{\mathrm{mM}}$, o coeficiente de correla ção foi 0,9996 e a linearidade do método foi obtida na faixa de concentração de $0,1-1,0 . \underline{\mathrm{mM}}$ (82).

A polarografia de corrente direta foi utilizada para determinar o cloridrato de ranitidina em comprimidos e injetáveis, utilizando-se tampão acetato pH 5,2 como suporte eletrolítico. Encontrou-se linearidade entre frequência e concentração e coeficiente de correlação igual a 0,9996 (1).

\subsubsection{2 - POTENCIOMETRIA}

Determinou-se cloridrato de ranitidina na matéria prima através de potenciometria em meio não aquoso, utilizando se ácido perclórico 0,1 M em ácido acético glacial como titulante e eletrodo de calomelano (4).

Utilizando-se hidróxido de sódio como titulante e água como solvente, o fámaca foi determinado em comprimidos atra vés de potenciometria (3).

Outro método potencionétrico desenvolvido para a determinação do cloridrato de ranitidina em comprimidos utilizou $\underline{e}$ 
letrodos ions-seletivos (com matrizes de PVC e de membrana líqui da). Obteve-se linearidade na faixa de concentração de $10^{-2}-10^{-6}$ $\underline{M}(\mathrm{pH} 2,0-7,0)(48)$.

2.3.4 - MÉTODOS DE DETERMINAÇÃO QUANTITATIVA EM FLUIDOS BIOLÓGICos

A cromatografia líquida de alta eficiência é o método mais utilizado para a bioanálise de ranitidina. Através desta técnica, o fármaco foi determinado em plasma $(8,30,37,38,39$, $46,49,57,59,67,68,70,80)$, sangue (68), tecido cerebral (30) e urina $(9,38,42,46,49,57,70)$.

Ranitidina foi determinada em soro e urina através de um método potenciométrico com eletrodos ions-seletivos e tampão acetato $\mathrm{pH} 4,6$. A quantidade minima detectada no soro foi 3 $\times 10^{-7}$ M (48). 
2.4 - UTILIZAÇAO DO REATIVO MBTH EM ESPECTROFOTOMETRIA NO VISI VEL

O MBTH (II), quimicamente a hidrazona da 3-metil 2-benzotiazolinona, foi desenvolvido em 1910, por BESTHORN( 5 ).<smiles>Cn1c(=NN)sc2ccccc21</smiles>

(II)

A capacidade de formar compostos coloridos com dife rentes grupamentos químicos possibilita vasta aplicação do MBTH em análise espectrofotométrica no visível.

O MBTH forma compostos coloridos com aldeídos (78), (55), várias aminas $(54,79)$ e compostos fenólicos (84).

Essas reações geralmente se processam em presença de um oxidante específico e condições definidas de $\mathrm{pH}$, o que confere características de seletividade à determinação de substâncias conten do esses grupamentos químicos, já que através de mecanismos diferentes, são formados produtos coloridos diferentes, com conse quentes leituras espectrofotométricas a comprimentos de onda distintos.

A aplicação de métodos espectrofotométricos no visí vel com MBTH na análise de medicamentos tem demonstrado ser uma boa alternativa, principalmente nos casos em que não existam recursos para o desenvolvimento de metodologias mais sofisticadas.

Entre os oxidantes utilizados na análise de fárma cos com MBTH podem ser citados o cloreto férrico $(22,72,73,74$, 
77), o sulfato férrico amoniacal $(19,20,21)$, o bicromato de po tássio (72), o metaperiodato de sódio (73, 76), a cloramina T (72) e o sulfato cérico amoniacal $(18,64,72,73,74,75)$. 
3 - PROPOSIÇÃO

o cloridrato de ranitidina vem sendo bastante utilizado e desperta grande interesse devido, principalmente, à sua potente ação no tratamento de úlceras pépticas.

Medicamentos contendo cloridrato de ranitidina 'são comercializados no Brasil e até o momento o fármaco não foi inscrito na Farmacopéia Brasileira. A metodologia oficial da Farmacopéia Americana para o seu doseamento é a cromatografia líquida de alta eficiência; a aplicação desta técnica analítica no Bra sil ainda é bastante dificultada, devido aos altos custos envolvi dos na obtenção e manutenção dos equipamentos e à necessidade de pessoal qualificado.

o objetivo deste trabalho foi padronizar métodos de análise precisos, sensíveis, de fácil execução e de custos mais baixos que aqueles envolvidos na metodologia proposta pela Farma copéia Americana. Assim, dois métodos espectrofotométricos (um -no visivel e outro no ultravioleta) foram propostos e aplicados na determinação do cloridrato de ranitidina em medicamentos comercializados no Brasil.

o método espectrofotométrico no visível foi baseado na reação entre o fármaco e o reativo $\mathrm{MBTH}$, em presença de clore to férrico, proposta por RAO e equipe (61).

o método espectrofotométrico no ultravioleta foi padronizado a $313 \mathrm{~nm}$, utilizando-se água destilada como solvente. 
4 - PLANEJAMENTO DA PESQUISA

4.1 - Revisão bibliográfica sobre o cloridrato de ranitidina.

4.1 - Levantamento das preparações farmacêuticas contendo clorị drato de ranitidina comercializadas no Brasil.

4.2 - Levantamento dos métodos de análise existentes na literatura para determinação do cloridrato de ranitidina em medicamentos.

4.3 - Seleção de métodos analíticos para determinação do cloridrato de ranitidina em medicamentos.

4.4 - Padronização dos métodos analíticos selecionados.

4.5 - Aplicação dos métodos padronizados na determinação do clo ridrato de ranitidina em amostras comerciais e simuladas, após estudo de interferência a partir dös outros componen tes adicionados às formulações.

4.6 - Realização de testes de recuperação em amostras comerciais e simuladas, a fim de comprovar a exatidão dos méto dos propastas.

4.7 - Estudo estatístico dos resultados obtidos, a fim de avali ar a reprodutibilidade dos métodos utilizados e de compará-los quanto à exatidão e precisão. 
5 - PARTE EXPERIMENTAL

5.1 - MATERIAL

5.1 .1 - REAGENTES E SOLUÇÕES

- Cloridrato da hidrazona da 3-metil-2-benzotiazolinona (MBTH) - Fluka

- Cloreto férrico hexahidratado - Merck

- Soluções de ácido clorídrico 0,01, 0,1M e 1,0M

Foram utilizados reagentes de grau de pureza analitico.

5.1 .2 - FÁRMACO UTILIZADO COMO SUBSTÂNCIA DE REFERÊNCIA

- Cloridrato de ranitidina - Chemotecnica, utilizado sem ứterior purificação.

5.1 .3 - AMOSTRAS

Amostra 1: (amostra comercial)

Comprimidos contendo $150,0 \mathrm{mg}$ de cloridrato de ranitidina.

Amostra 2: (amostra comercial)

Solução injetável contendo 50, Omg de cloridrato de rani tidina/5, OmL, pH 6,8.

Amostra 3: (amostra comercial)

Solução injetável contendo 56, omg de cloridrato de rani 
tidina/2, Oml, $\mathrm{pH} 6,8$.

Amostra 4: (amostra comercial)

Comprimidos contendo $167,4 \mathrm{mg}$ de cloridrato de ranitidina.

Amostra 5: (amostra simulada)

Comprimidos

Cloridrato de ranitidina .................... 00mg Lactose ........................ 87, o0mg Celulose microcristalina .............45, oomg

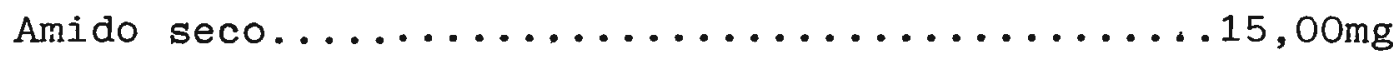

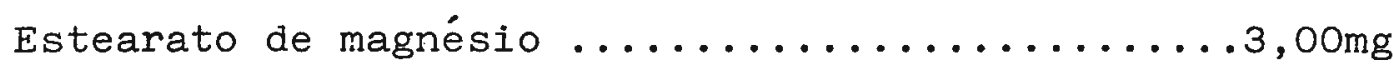
Total $=300$, oomg

Amostra 6: (amostra simulada)

Solução injetável, pH 6,8

Cloridrato de ranitidina ................. 00mg Álcool benzilico ............................. oomg Solução fisiológica q.s.p. ................ $00 \mathrm{ml}$

Amostra 7: (amostra simulada)

Solução injetável, $\mathrm{pH} 6,8$

Cloridrato de ranitidina ................... 00mg Fenol .................................. 00mg Solução fisiológica q.s.p. ................... o0ml 
Todas as substâncias empregadas na preparação das amostras simuladas foram de grau farmacêutico.

\section{1 .4 - EQUIPAMENTOS}

Além dos equipamentos normalmente utilizados em la boratórios de controle de qualidade de medicamentos, fo ram empregados os seguintes:

- Espectrofotômetro BECKMAN, modelo DU-70, munido de im pressora, com cubetas de 1, 0cm.

- Medidor de pH DIGIMED, modelo TE-901. 
5.2 - MÉTODOS

5.2.1. - ESPECTROFOTOMETRIA NO ULTRAVIOLETA

5.2 .1 .1 - PADRONIZAÇ̃̃O DO MÉTODO

5.2.1.1.A - CONSTRUÇÃO DA CURVA DE RINGBOM

Foram pesados exatamente $100,0 \mathrm{mg}$ de cloridrato de ranitidina, os quais foram transferidos para balão volumétrico de $100 \mathrm{~mL}$. Adicionou-se q.s. de água destilada para dissolução e completou-se o volume com o mesmo solvente. Transferiu-se uma alíquota de $50,0 \mathrm{~mL}$ para balão volumétrico de $500 \mathrm{~mL}$ e completouse o volume com água destilada. Desta solução, foram transferi das 25 alíquotas, cujos volumes variaram de 1,0 a $25,0 \mathrm{~mL}$, para balões volumétricos de $100 \mathrm{~mL}$, completando-se os volumes com á gua destilada. Foram obtidas, assim, soluções com concentrações variando entre 1,0 e $25,0 \mu \mathrm{g}$ de cloridrato de ranitidina/mL.

As leituras de absorbância destas soluções foram efe tuadas contra branco de água destilada, a $313 \mathrm{~nm}$.

Através dos resultados obtidos, construiu-se a curva de Ringbon, determinando-se a faixa de concentração de cloridrato de ranitidina na qual o método espectrofotométrico no ultravioleta obedece à lei de Beer.

5.2.1.1.B - CONSTRUÇÃO DA RETA DE CALIBRAÇÃO

Determinada a faixa de concentração na qual o método obedece à lei de Beer, construiu-se a reta de calịbração com os resultados obtidos na leitura das absorbâncias das soluções com concentrações iguais a $5,0,7,0,8,0,10,0,11,0,12,0$, $14,0,15,0,16,0$, e $18,0 \mu \mathrm{g}$ de cloridrato de ranitidi 
$\mathrm{na} / \mathrm{mL}$.

5.2.1.2 - APLICAÇÃO DO MÉTODO PADRONIZADO A AMOSTRAS COMERCIAIS E SIMULADAS

5.2.1.2.1 - PESQUISA DE INTERFERÊNCIA A PARTIR DOS EXCIPIENTES

Com o objetivo de verificar a existência de interfe rentes no método, algumas preparações foram simuladas e seus placebos foram analisados.

5.2.1.2.1.A - Preparo do padrão $P$

Foram pesados exatamente $150,0 \mathrm{mg}$ de cloridrato de ranitidina e transferidos para balão volumétrico de $250 \mathrm{~mL}$. Adici onou-se q.s. de água destilada para dissolução e completou-se o volume com o mesmo solvente. Desta solução fói transferida uma alíquota de $5,0 \mathrm{~mL}$ para balão volumétrico de $250 \mathrm{~mL}$ e completou-se - volume com água destilada. A solução padrão $\mathrm{P}$ continha $12,0 \mu \mathrm{g}$ de cloridrato de ranitidina/mL.

5.2.1.2.1.B - Preparo do padrão $P_{1}$

Foram pesados exatamente $100,0 \mathrm{mg}$ de cloridrato de ranitidina e tranferidos para balão volumétrico de $250 \mathrm{~mL}$. Adicionou-se q.s. de água destilada para dissolução e completou-se o volume com o mesmo solvente. Desta solução foi transferida uma alíquota de $5,0 \mathrm{~mL}$ para balão volumétrico de $200 \mathrm{~mL}$, completando se o volume com água destilada. A solução padrão $\mathrm{P}_{1}$ continha 10,0 $\mu \mathrm{g}$ de cloridrato de ranitidina/mL.

5.2.1.2.1.C - Preparo do padrão $\mathrm{P}_{2}$ 
Foram pesados exatamente $56,0 \mathrm{mg}$ de cloridrato de ranitidina e transferidos para balão volumétrico de $200 \mathrm{~mL}$. Adicionou-se q.s. de água para dissolução e completou-se o volume com o mesmo solvente. Desta solução, transferiu-se uma alíquota de $5,0 \mathrm{~mL}$ para balão volumétrico de $100 \mathrm{~mL}$ e completou-se o volu me com água destilada. A solução padrão $\mathrm{P}_{2}$ continha $14,0 \mu \mathrm{g}$ de cloridrato de ranitidina/mL.

5.2.1.2.1.D - Preparo das amostras 1, 4 e 5

Destas amostras foram pesadas quantidades que continham, teoricamente, 150,0 $\mathrm{mg}$ de cloridrato de ranitidina e transferidas para balões volumétricos de $250 \mathrm{~mL}$. Foram adicionados $100 \mathrm{~mL}$ de água destilada, agitando-se durante $10 \mathrm{minu}$ tos. Os volumes foram completados com o mesmo solvente, filtrando-se en séguida. Rejeitados os primeiros $10 \mathrm{~mL}$ dos filtrados, foram transferidas alíquotas de $5,0 \mathrm{~mL}$ dos mesmos para balões vo lumétricos de $250 \mathrm{~mL}$, completando-se os volumes com água destila da.

5.2.1.2.1.E - Preparo do placebo da amostra 5

Foi pesada do placebo uma quantidade equivalente ao peso do excipiente contido na amostra 5, utilizada no preparo da solução do ítem anterior, seguindo-se o mesmo procedimento da quele ítem.

5.2.1.2.1.F - Preparo das amostras 2 e 6 , e do placebo da amos tra 6

Foram transferidos 2,0 mL das amostras e do placebo para balões volumétricos de $50 \mathrm{~mL}$, completando-se os volumes com água destilada. Destas soluções foram transferidas alíquotas de $5,0 \mathrm{~mL}$ para balões volumétricos de $200 \mathrm{~mL}$, completando-se os 
volumes com o mesmo solvente.

5.2.1.2.1.G - Preparo das amostras 3 e 7 , e do placebo da amostra 7

Transferiu-se $1,0 \mathrm{~mL}$ das amostras e do placebo para balões volumétricos de $100 \mathrm{~mL}$, completando-se os volumes com água destilada. Destas soluções, foram transferidas alíquotas de 5,0 $\mathrm{mL}$ para balões volumétricos de $100 \mathrm{~mL}$, completando-se os volumes com o mesmo solvente.

Foram traçados os espectros de todas as soluções, de 400 a $200 \mathrm{~nm}$, contra branco de água destilada.

5.2.1.2.2 - DETERMINAÇÃO DO TEOR DE CLORIDRATO DE RANITIDINA NAS AMOSTRAS COMERCIAIS $(1,2,3$ e 4) E SIMULADAS $(5,6$ e 7)

5.2.1.2.2.A - Preparo do padrão

Seguiu-se o mesmo procedimento descrito no item 5 . 2.1.2.1.A, obtendo-se uma solução com 12,o $\mu \mathrm{g}$ de cloridrato de ra nitidina/mL. Foram efetuadas as leituras de absorbância de três soluções de cloridrata de ranitidina padrão, a. $313 \mathrm{~nm}$, contra branco de água destilada.

5.2.1.2.2.B - Preparo das amostras

As amostras 1, 4 e 5, 2 e 6 , e 3 e 7 foram preparadas conforme os procedimentos descritos nos itens 5.2.1.2.1.D, 5 . 2.1.2.1.F e 5.2.1.2.1.G, respectivamente. Foram efetuadas as leituras de absorbância, a $313 \mathrm{~nm}$, fazendo-se 10 determinações para cada amostra. 
5.2.1.3 - TESTE DE RECUPERAÇÃO

o teste de recuperação é efetuado para comprovar a exa tidão do método (85). Consiste em adicionar à amostra quantida des conhecidas da substância padrão, empregando-se em seguida,o método proposto de análise.

5.2.1.3.A - Preparo do padrão

Foram pesados exatamente $100,0 \mathrm{mg}$ de cloridrato de ranitidina e transferidos para balão volumétrico de $250 \mathrm{~mL}$. Adicionou-se q.s. de água destilada para dissolução e completou- se - volume com o mesmo solvente. Esta solucão continha 400, o $\mu \mathrm{g}$ de cloridrato de ranitidina/mL.

5.2.1.3.B - Preparo das amostras 1,4 e 5

Destas amostras foram pesadas quantidades que continham, teoricamente, $100,0 \mathrm{mg}$ de cloridrato de ranitidina e trans feridas para balões volumétricos de $250 \mathrm{~mL}$. Foram adicionados $100 \mathrm{~mL}$ de água destilada, agitando-se durante dez minutos. Os vo lumes foram completados com o mesmo solvente e após filtração, os primeiros $10 \mathrm{~mL}$ foram rejeitados.

5.2.1.3.C - Preparo das amostras 2 e 6

Foram transferidos $2,0 \mathrm{~mL}$ destas amostras para ba lões volumétricos de $50 \mathrm{~mL}$, completando-se os volumes com água destilada.

5.2.1.3.D - Preparo das amostras 3 e 7

Foram transferidos $2,0 \mathrm{~mL}$ destas amostras para ba- 
lões volumétricos de $200 \mathrm{~mL}$, completando-se os volumes com água destilada.

Para o teste foram transferidas alíquotas das amostras e do padrão, segundo o esquema abaixo, para balões volumé tricos de $200 \mathrm{~mL}$ (amostras 3 e 7) e de $250 \mathrm{~mL}$ (amostras 1, 2, 4, 5 e 6 ).

Esquema para realização do teste de recuperação:

\begin{tabular}{lc}
\hline $\begin{array}{c}\text { Amostra } \\
(\mathrm{mL})\end{array}$ & $\begin{array}{c}\text { Pađrão } \\
(\mathrm{mL})\end{array}$ \\
\hline- & 5,0 \\
5,0 & 1,0 \\
5,0 & 2,0 \\
5,0 & 5,0 \\
5,0 & - \\
\hline
\end{tabular}

Os volumes foram completados com água destilada e as leituras de absorbância foram efetuadas a $313 \mathrm{~nm}$, contra branco do mesmo solvente.

A porcentagem de recuperação (\%R) foi calculada pela expressão:

$$
\% R=\left(C_{A}-C_{N A}\right) / C_{P} \times 100
$$

onde: $\mathrm{C}_{\mathrm{A}}=$ Concentração de cloridrato de ranitidina encontrada na amostra adicionada de padrão.

$\mathrm{C}_{\mathrm{NA}}=$ Concentração de cloridrato de ranitidina encon trada na amostra não adicionada de padrão.

$\mathrm{C}_{\mathrm{P}}=$ Concentração do padrão. 
5.2 .2 - ESPECTROFOTOMETRIA NO VISÍVEL

5.2.2.1 - PADRONIZAÇÃO DO MÉTODO

5.2.2.1.A - ESTUDO DOS PRINCIPAIS FATORES QUE INFLUENCIAM A REAÇÃO

5.2.2.1.A.1 - DETERMINAÇÃO DA CONCENTRAÇÃO ÓTIMA DE MBTH E CLORE TO FÉRRICO

Preparo do padrão

Foram pesados exatamente $150,0 \mathrm{mg}$ de cloridrato de ranitidina e transferidos para balão volumétrico de $250 \mathrm{~mL}$. Adicionou-se q.s. de água destilada para dissolução e completou- se - volume com o mesmo solvente. Desta solução foi transferida uma alíquota de $10,0 \mathrm{~mL}$ para balão volumétrico de $100 \mathrm{~mL}$, comple tando-se o volume com $\mathrm{HCl}$ 0,1 M. Esta solução continha $60,0 \mu \mathrm{g}$ de cloridrato de ranitidina/mL.

$\underline{\text { Preparo das soluções de MBTH }}$

Foram pesados exatamente $50,0,100,0,150,0,200,0$, $250,0,300,0,350,0,400,0,450,0$ e 500,0 mg de MBTH e transferidos para balões volumétricos de $100 \mathrm{~mL}$. A cada balão adicionou se q.s. de $\mathrm{HCl} 0,1$ M para dissolução, completando-se os volumes com o mesmo solvente. As soluções obtidas tinham concentrações de $0,05,0,10,0,15,0,20,0,25,0,30,0,35,0,40,0,45$ e $0,50 \%$, respectivamente.

$\underline{\text { Preparo das soluções de cloreto férrico }}$

Foram pesados exatamente $200,0,300,0,400,0$, 
500,0 e $1000,0 \mathrm{mg}$ de cloreto férrico, e transferidos para balões volumétricos de $100 \mathrm{~mL}$. A cada balão adicionou-se q.s. de HCl 0,1 M para dissolução, completando-se os volumes com o mesmo sol vente. As soluções obtidas tinham concentrações de $0,20,0,30$, $0,40,0,50$ e $1,00 \%$, respectivamente.

\section{Procedimento}

Para a realização dos testes foram transferidas para 35 balões volumétricos de $50 \mathrm{~mL}$, alíquotas de $5,0 \mathrm{~mL}$ da solução padrão, 2,0 mL de solução de $\mathrm{MBTH}$ e $5,0 \mathrm{~mL}$ de solução de cloreto férrico, conforme o esquema:

\begin{tabular}{|c|c|c|c|c|c|c|c|c|c|c|}
\hline $\begin{array}{l}\text { Conc. } \\
\text { MBTH (\%) }\end{array}$ & 0,05 & 0,10 & 0,15 & 0,20 & 0,25 & 0,30 & 0,35 & 0,40 & 0,45 & 0,50 \\
\hline $\mathrm{FeCl}_{3}(\%)$ & & & & & & . & & & & \\
\hline 0,20 & $x$ & $\mathrm{x}$ & $x$ & $x_{-}$ & $x$ & $x$ & $\mathbf{x}$ & $x$ & $x$ & $x$ \\
\hline 0,30 & & $\mathbf{x}$ & & $\mathbf{x}$ & & $\mathbf{x}$ & $x$ & $x$ & & $\mathbf{x}$ \\
\hline 0,40 & & $x$ & $x$ & $\mathbf{x}$ & $x$ & $x$ & $x$ & $\mathbf{x}$ & $\mathbf{x}$ & $x$ \\
\hline 0,50 & & $x$ & & $x$ & & $x$ & & $x$ & & $\mathbf{x}$ \\
\hline 1,00 & & $x$ & & $x$ & & $\dot{x}$ & & $\mathbf{x}$ & & $\mathbf{x}$ \\
\hline
\end{tabular}

Após homogeneização e repouso de trinta minutos, foram medidas as absorbâncias a $615 \mathrm{~nm}$, contra os respectivos brancos 
(trinta e cinco), que foram preparados sob as-mesmas condições descritas, porém, substituindo-se a solução padrão por $5,0 \mathrm{~mL}$ de $\mathrm{HCl} 0,1 \underline{\mathrm{M}}$.

Com os resultados obtidos, foram construídas as curvas, através das quais foram determinadas as concentrações de MBTH e cloreto férrico que forneceram maior estabilidade à reação.

5.2.2.1.A.2 - DETERMINAÇÃO DA CONCENTRAÇÃO DA SOLUÇÃO DE HCI UTI LIZADA COMO SOLVENTE

Para esta determinação foram efetuadas reações a partir de soluções de cloridrato de ranitidina, MBTH e cloreto férrico, preparadas com os seguintes solventes:

- Água destilada;

- $\mathrm{HCl} 0,01 \underline{\mathrm{M}}$;

- $\mathrm{HCl} 0,1 \underline{\mathrm{M}}$;

$-\operatorname{HCl} 1,0 \underline{\mathrm{M}}$.

Preparo dos padrões

Foram pesados exatamente $100,0 \mathrm{mg}$ de cloridrato de ranitidina e transferidos para balão volumétrico de $250 \mathrm{~mL}$. A dicionou-se q.s de água destilada para dissolução e completou-se o volume com o mesmo solvente. Desta solução, foram transferidas alíquotas de $10,0 \mathrm{~mL}$ para balões volumétricos de $100 \mathrm{~mL}$. Completou-se o volume do primeiro balão com água destilada (padrão 1), o do segundo con $\mathrm{HCl}$ 0,01 M (padrão 2), o do terceiro com HCl 0,1 M (padrão 3) e o quarto com $\mathrm{HCl}^{1,0}$ M ( padrão 4). Estas soluções continham $40,0 \mu \mathrm{g}$ de cloridrato de ranitidina/mL. 
Preparo das soluções de MBTH

Foram efetuadas quatro pesagens de, exatamente, 350,0 mg de MBTH, que foram transferidos para balões volumétricos de $100 \mathrm{~mL}$. Ao primeiro balão adicionou-se q.s. de água destilada pą ra dissolução, completando-se o volume com o mesmo solvente (MBTH 1). Seguindo-se o mesmo procedimento, foram preparadas as soluções de $\mathrm{MBTH} 2,3$ e 4, utilizando-se $\mathrm{HCl} 0,01 \underline{\mathrm{M}}, 0,1 \underline{\mathrm{M}}$ e $1,0 \underline{\mathrm{M}}$, respectivamente, como solventes.

$\underline{\text { Preparo das soluções de cloreto férrico }}$

Foram efetuadas quatro pesagens de, exatamente, 400,0 mg de cloreto férrico, que foram transferidos para balões volumétricos de $100 \mathrm{~mL}$. Ao primeiro balão adicionou-se q.s. de água destilada para dissolução, completando-se o volume com o mesmo solvente $\left(\mathrm{FeCl}_{3} 1\right)$. Seguindo-se o mesmo procedimento, foram prepa radas as soluções de $\mathrm{FeCl}_{3} 2,3$ e 4, utilizando-se $\mathrm{HCl} 0,01 \mathrm{M}$, $0,1 \underline{M}$ e $1,0 \underline{M}$, respectivamente, como solventes.

\section{$\underline{\text { Procedimento }}$}

Foram transferidas para doze balões volumétricos de $50 \mathrm{~mL}$, alíquotas de $5,0,2,0$ e $5,0 \mathrm{~mL}$ das soluções (padrão, MBTH e cloreto férrico, respectivamente) preparadas com o mesmo solven te (padrão 1 , MBTH 1 e $\mathrm{FeCl}_{3} 1$, por exemplo). Após homogeneização e repouso de trinta minutos, os volumes foran completados com á gua destilada e as absorbâncias foram medidas a $615 \mathrm{~nm}$, contra os respectivos brancos, preparados sob as mesmas condições descritas, porém, substituindo-se o padrão por $5,0 \mathrm{~mL}$ de água destila da, $\mathrm{HCl} 0,01 \underline{\mathrm{M}}, .0,1 \underline{\mathrm{M}}$ e $1,0 \underline{\mathrm{M}}$, conforme o caso.

Com os resultados obtidos, verificou-se a influência 
da concentração de $\mathrm{HCl}$ sobre o desenvolvimento da reação.

5.2.2.1.A.3 - DETERMINAÇÃO DO TEMPO NECESSÁRIO PARA A ESTABILIZAÇÃO DA REAÇÃO

Preparo do padrão

Foram pesados exatamente $100,0 \mathrm{mg}$ de cloridrato de ranitidina e transferidos para balão volumétrico de $250 \mathrm{~mL}$. Adicionou-se q.s. de água destilada para dissolução, completando-se o volume com o mesmo solvente. Foi transferida uma alíquo ta de $5,0 \mathrm{~mL}$ para balão volumétrico de $200 \mathrm{~mL}$, completando-se o volume com $\mathrm{HCl} 0,1$ M. Esta solução continha $10,0 \mu \mathrm{g}$ de cloridra to de ranitidina/mL.

Preparo da solução de MBTH a $0,35 \%$

Foram pesados exatamente $350,0 \mathrm{mg}$ de $\mathrm{MBTH}$ e transferidos para balão volumétrico de $100 \mathrm{~mL}$. Adicionou-se q. s. de HCl 0,1 M para dissolução e completou-se o volume com o mesmo solvente. Esta solução tinha concentração de 0,35\% e este foi o procedimento adotado para o preparo das soluções de MBTH utilizadas no restante do trabalho.

\section{Preparo da solução de cloreto férrico a $0,40 \%$}

Foram pesados exatamente $400,0 \mathrm{mg}$ de cloreto férrico e transferidos para balão volumétrico de $100 \mathrm{~mL}$. Adicionou -se q.s. de $\mathrm{HCl}$ 0,1 M para dissolução, completando-se o volume com o mesmo solvente. Esta solução tinha concentração de $0,40 \%$ e este foi o procedimento adotado para o preparo das soluções de cloreto férrico utilizadas no restante do trabalho. 


\section{Procedimento}

Foram transferidos para um tubo de ensaio 5,0 mL de solução padrão, 2,0 mL de solução de $\mathrm{MBTH}$ a $0,35 \%$ e 5,0 mL de so lução de cloreto férrico a 0,40\%. Após homogeneização, transfe riu-se diretamente para a cubeta do espectrofotômetro, efetuando -se as medidas de ábsorbância de zero a quarenta e cinco minu tos, depois de calibrar o aparelho com o branco da reação.

5.2.2.1.A.4 - VERIFICAÇÃO DA INFLUÊNCIA DA ADIÇÃO DE ÁGUA NO DESENVOLVIMENTO DA REAÇÃO

$\underline{\text { Preparo do padrão }}$

Foram pesados exatamente $100,0 \mathrm{mg}$ de cloridrato de ranitidina e transferidos para balão volumétrico de $250 \mathrm{~mL}$. A dicionou-se q.s. de água destilada para dissolução, completandose o volume com o mesmo solvente. Transferiu-se uma alíquota de $10,0 \mathrm{~mL}$ para balão volumétrico de $100 \mathrm{~mL}$ e completou-se o volume

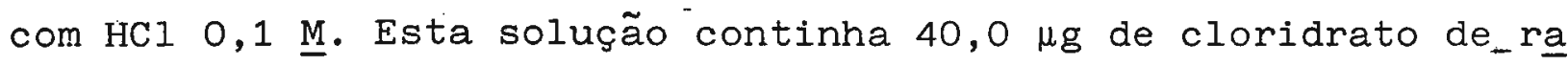
nitidina/mL.

\section{$\underline{\text { Procedimento }}$}

Foram transferidos para dois balões volumétricos de $50 \mathrm{~mL}, 5,0 \mathrm{~mL}$ de solução padrão, 2,0 mL de solução de MBTH a $0,35 \%$ e $5,0 \mathrm{~mL}$ de solução de cloreto férrico a 0,40\%. Completouse o volume do primeiro barão com água destilada logo após a a dição dos reagentes. o volume do segundo balão foi completado trinta minutos após a adição dos reagentes. As medidas de absorbância foram efetuadas depoịs que o volume do segundo balão foi completado, a $615 \mathrm{~nm}$, contra os respectivos brancos. 
5.2.2.1.A.5 - DETERMINAÇÃO DO TEMPO DE ESTABILIDADE DA REAÇ̃̃O

$\underline{\text { Preparo do padrão }}$

Seguiu-se o mesmo procedimento descrito para 0 prepa ro do padrão do ítem 5.2.2.1.A.4.

$\underline{\text { Procedimento }}$

Foram transferidos para balão volumétrico de $50 \mathrm{~mL}$, $5,0 \mathrm{~mL}$ da solução padrão, $2,0 \mathrm{~mL}$ da solução de $\mathrm{MBTH}$ a $0,35 \%$ e $5,0 \mathrm{~mL}$ da solução de cloreto férrico a 0,40\%. Após homogeneização e trinta minutos de repouso, o volume foi completado com água destilada. As leituras de absorbância foram efetuadas a $615 \mathrm{~nm}$, durante cento e vinte minutos, após calibração do aparelho com o branco da reação.

5.2.2.1.A' - DETERMINAÇÃO DA RELAÇÃO ESTEQUIOMÉTRICA ENTRE O CLO RIDRATO DE RANITIDINA E O MBTH

o estudo da relação estequiométrica entre o clori drato de ranitidina e o MBTH baseou-se no método da "variação contínua", de JOB (36). Este método foi aplicado na determinação da relação estequiométrica entre O MBTH e outros fármacos em presença do ín férrico $(20,21)$.

Para a determinação preparam-se soluções das espécies em estudo com a mesma concentração molar. Em seguida, são variadas as proporções das soluções, aplicando-se o método de $\underline{a}$ nálise. Para métodos espectrofotométricos, a relação estequiométrica é obtida pela proporção (entre os volumes das soluções) de maior absorbância.

o teste foi realizado a partir das soluções de clo 
ridrato de ranitidina e de $\mathrm{MBTH}$, ambas com concentração de 7,27 $\times 10^{-4} \mathrm{M}, \mathrm{e}$ da solução de cloreto férrico a $0,40 \%$.

\section{$\underline{\text { Procedimento }}$}

Foram transferidas para 28 balões volumétricos de 50 $\mathrm{mL}$, aliquotas complementares de 0,0 a $10,0 \mathrm{~mL}$ de soilução de clo ridrato de ranitidina e $\mathrm{MBTH}$, conforme o esquema do quadro 5.1 .

A cada balão foram adicionados $5,0 \mathrm{~mL}$ de solução de cloreto férrico a $0,40 \%$ e após homogeneização e repouso de trinta minutos, completaram-se os volumes com água destilada. As absorbâncias foram medidas a $615 \mathrm{~nm}$, contra os respectivos brancos, preparados da mesma maneira, porém, substituindo-se a solução padrão por HCl $0,1 \underline{M}$.

Com os resultados obtidos, construiu-se a curva atra vés da qual foi determinada a proporção de cloridrato de ranitidina e MBTH que forneceu a maior leitura de absorbância.

\subsubsection{B - DETERMINAÇÃO DO ESPECTRO DE ABSORÇÃO DA REAÇÃO}

Para esta determinação utilizou-se a solução padrão contendo $40,0 \mu \mathrm{g}$ de cloridrato de ranitidina/mL, preparada como no item $5.2 \cdot 2 \cdot 1$. A.4.

\section{Procedimento}

Foram transferidos para balão volumétrico de $50 \mathrm{~mL}$, $5,0 \mathrm{~mL}$ de solução padrão, $2,0 \mathrm{~mL}$ de solução de $\mathrm{MBTH}$ a $0,35 \%$ e $5,0 \mathrm{~mL}$ de solução de cloreto férrico a 0,40\%. Após homogeneiza ção e repouso de trinta minuțos, completou-se o volume com água destilada e traçou-se o espectro de absorção, de 700 a $400 \mathrm{~nm}$, contra branco preparado sob as mesmas condições, porém, substitú 
Quadro 5.1 - Esquema da variação dos volumes das soluções de clo ridrato de ranitidina e MBTH para a determinação da relação estequiométrica.

\begin{tabular}{|c|c|c|c|}
\hline $\begin{array}{l}\text { Balão } \\
n \stackrel{0}{ }\end{array}$ & $\begin{array}{l}\text { Solução de } \\
\text { ranitidina }\end{array}$ & $\begin{array}{l}\text { cloridrato } \\
(\mathrm{mL})\end{array}$ & $\begin{array}{c}\text { solução de MBTH } \\
(\mathrm{mL})\end{array}$ \\
\hline 1 & - & . & 10,0 \\
\hline 2 & 0,1 & - & 9,9 \\
\hline 3 & 0,2 & & 9,8 \\
\hline 4 & 0,3 & & 9,7 \\
\hline 5 & 0,4 & & 9,6 \\
\hline 6 & 0,5 & & 9,5 \\
\hline 7 & 0,7 & & 9,3 \\
\hline 8 & 1,0 & & 9,0 \\
\hline 9 & 1,1 & & 8,9 \\
\hline 10 & 1,2 & & 8,8 \\
\hline 11 & 1,4 & & $-8,6$ \\
\hline 12 & 1,5 & & 8,5 \\
\hline 13 & 2,0 & & 8,0 \\
\hline 14 & 2,2 & . & 7,8 \\
\hline 15 & 2,3 & & 7,7 \\
\hline 16 & 2,5 & & 7,5 \\
\hline 17 & 2,7 & & 7,3 \\
\hline 18 & 2,8 & & 7,2 \\
\hline 19 & 3,0 & & 7,0 \\
\hline 20 & 3,3 & & 6,7 \\
\hline 21 & 3,5 & & 6,5 \\
\hline 22 & 4,0 & & 6,0 \\
\hline 23 & 5,0 & & 5,0 \\
\hline 24 & 6,0 & & 4,0 \\
\hline 25 & 7,0 & . & 3,0 \\
\hline 26 & 8,0 & . & 2,0 \\
\hline 27 & 9,0 & & 1,0 \\
\hline 28 & 10,0 & & - \\
\hline
\end{tabular}


indo-se a solução padrão por HCl 0,1 M.

5.2.2.1.C - CONSTRUÇÃO DA CURVA DE RINGBOM

\section{$\underline{\text { Preparo do padrão }}$}

Foram pesados exatamente $300,0 \mathrm{mg}$ de cloridrato de ranitidina e transferidos para balão volumétrico de $250 \mathrm{~mL}$. Adicionou-se q.s. de água destilada para dissolução e completou- se - volume com o mesmo solvente. Desta solução, foi transferida uma alíquota de $10,0 \mathrm{~mL}$ para balão volumétrico de $100 \mathrm{~mL}$, comple tando-se o volume com HCl 0,1 M. Esta solução continha $120 \mathrm{\mu g}$ de cloridrato de ranitidina/mL.

\section{Procedimento}

Foram transferidas para balões volumétricos de $50 \mathrm{~mL}$ alíquotas da solução padrão, conforme o esquema do quadro 5.2 .

A cada balão foram adicionados $2,0 \mathrm{~mL}$ de solução de MBTH a $0,35 \%$ e $5,0 \mathrm{~mL}$ de solução de cloreto férricio a $0,40 \%$. Após homogeneização e repouso de trinta minutos, completou-se o volume com água destilada. As soluções obtidas tinham concentrações variando de 0,48 a $10,08 \mu \mathrm{g}$ de cloridrato de ranitidina/mL. As leituras de absorbância foram efetuadas a $615 \mathrm{~nm}$, contra bran co preparado sob as mesmas condições, substituindo-se a solução padrão por HCl 0,1 M.

Com os resultados obtidos construiu-se a curva de Ringbon. 
Quadro 5.2 - Esquema de preparação das soluções de cloridrato de ranitidina para construção da curva de Ringbom.

\begin{tabular}{|c|c|c|c|}
\hline $\begin{array}{c}\text { Balão } \\
\text { n̊ }\end{array}$ & Volume de & $\begin{array}{l}\text { solução padrão. } \\
\text { (mL) }\end{array}$ & $\begin{array}{c}\text { Vol. de } \mathrm{HCl} 0,1 \mathrm{M} \\
(\mathrm{mL})\end{array}$ \\
\hline 1 & & 0,2 & 4,8 \\
\hline 2 & & 0,4 & 4,6 \\
\hline 3 & & 0,6 & 4,4 \\
\hline 4 & & 0,8 & 4,2 \\
\hline 5 & & 1,0 & 4,0 \\
\hline 6 & & 1,2 & 3,8 \\
\hline 7 & & 1,4 & 3,6 \\
\hline 8 & & 1,6 & 3,4 \\
\hline 9 & & 1,8 & 3,2 \\
\hline 10 & & 2,0 & 3,0 \\
\hline 11 & & 2,2 & 2,8 \\
\hline 12 & & 2,4 & 2,6 \\
\hline 13 & & 2,6 & 2,4 \\
\hline 14 & & 2,8 & 2,2 \\
\hline 15 & & 3,0 & 2,0 \\
\hline 16 & & 3,2 & 1,8 \\
\hline 17 & 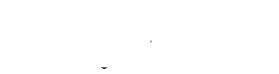 & 3,4 & 1,6 \\
\hline 18 & & 3,6 & 1,4 \\
\hline 19 & & 3,8 & 1,2 \\
\hline 20 & & 4,0 & 1,0 \\
\hline 21 & & 4,2 & 0,8 \\
\hline
\end{tabular}


5.2.2.1.D - CONSTRUÇÃO DA RETA DE CALIBRAÇÃO

Com os dados obtidos na construção da curva de Ringbon, construiu-se a reta de calibração do método, utilizando -se os resultados das medidas de absorbância das soluções com concentrações iguais a $1,44,1,92,2,40,2,88,3,36,3,84,4,32$, $4,80,5,28$ e 5,76 $\mu \mathrm{g}$ de cloridrato de ranitidina/mL.
5.2.2.2 - APLICAÇÃO DO MÉTODO PADRONIZADO A AMOSTRAS COMERCIAIS E SIMULADAS

5.2.2.2.1 - PESQUISA DE INTERFERÊNCIA A PARTIR DOS EXCIPIENTES

5.2.2.2.1.A - Preparo do padrão

Seguiu-se o procedimento descrito no item 5.2.2.1.

A. 4 .

5.2.2.2.1.B - Preparo das amostras 1, 4 e 5

Foi pesada de cada amostra uma quantidade que con tinha, teoricamente, $100,0 \mathrm{mg}$ de cloridrato de ranitidina, trans ferindo-se para balão volumétrico de $250 \mathrm{~mL}$. Foram adicionados $100 \mathrm{~mL}$ de água destilada, agitando-se durante dez minutos. Completou-se o volume com o mesmo solvente e filtrou-se, desprezando-se os primeiros $10,0 \mathrm{~mL}$ do filtrado. Transferiu-se uma alíquo ta de $10,0 \mathrm{~mL}$ para balão volumétrico de $100 \mathrm{~mL}$ e completou-se o volume com $\mathrm{HCl} 0,1 \underline{\mathrm{M}}$.

5.2.2.2.1.C - Preparo do placebo da amostra 5

Foi pesada uma quantidade do placebo, equivalente ao peso do excipiente contido na amostra 5, utilizada no preparo 
da solução do item anterior, seguindo-se aquele procedimento. 5.2.2.2.1.D - Preparo das amostras 2 e 6 , e do placebo da amostra 6

Foram transferidos $2,0 \mathrm{~mL}$ de cada amostra e do placebo para balões volumétricos de $100 \mathrm{~mL}$, completando-se os volumes com água destilada. Destas soluções foram transferidas alíquotas de $10,0 \mathrm{~mL}$ para balões volumétricos de $50 \mathrm{~mL}$, completando-se os volumes com $\mathrm{HCl} 0,1 \mathrm{M}$.

5.2.2.2.1.E - Preparo das amostras 3 e.7, e do placebo da amostra 7

Foram transferidos $2,0 \mathrm{~mL}$ de cada amostra e do placebo para balões volumétricos de $250 \mathrm{~mL}$, completando-se os volumes com água destillada. Destas soluções, foram transferidas alíquotas de $10,0 \mathrm{~mL}$ para balões volumétricos de $50 \mathrm{~mL}$, completando-se os volumes com $\mathrm{HCl} 0,1 \mathrm{M}$.

5.2.2.2.1.F - Procedimento

Para a reação seguiu-se o esquema abaixo:

\begin{tabular}{|c|c|c|c|c|c|}
\hline & $\begin{array}{l}\text { Sol. } \\
\text { padrão } \\
(\mathrm{mL})\end{array}$ & $\begin{array}{l}\text { Sol. } \\
\text { amostra } \\
(\mathrm{mL})\end{array}$ & $\underset{(\mathrm{mL})}{\mathrm{HCI} O, 1 \underline{\mathrm{M}}}$ & $\begin{array}{l}\text { MBTH a } 0,35 \% \\
(\mathrm{~mL})\end{array}$ & $\begin{array}{l}\mathrm{FeCl}_{3} \mathrm{a} \\
0,40^{3} \% \\
(\mathrm{~mL})\end{array}$ \\
\hline $\begin{array}{l}\text { Balão } \\
\text { padrão }\end{array}$ & 5,0 & - & - & 2,0 & 5,0 \\
\hline $\begin{array}{l}\text { Balão } \\
\text { amostra }\end{array}$ & - & 5,0 & - & 2,0 & 5,0 \\
\hline $\begin{array}{l}\text { Balão } \\
\text { branco }\end{array}$ & - & - & 5,0 & 2,0 & 5,0 \\
\hline
\end{tabular}


Após homogeneização e repouso de trinta minutos, os volumes foram completados com água destilada e os espectros foram traçados, de 700 a $400 \mathrm{~nm}$, contra o branco da reação.

5.2.2.2.2 - DETERMINAÇÃO DO TEOR DE CLORIDRATO DE RANITIDINA NAS AMOSTRAS COMERCIAIS $(1,2,3$ e 4) E SIMULADAS $(5,6$ e 7)

5.2.2.2.2.A - Preparo do padrão

Seguiu-se o procedimento descrito no item 5.2.2.1.

A. 4 .

5.2.2.2.2.B - Preparo das amostras 1, 4 e 5

Seguiu-se o procedimento descrito no ítem 5.2.2.2.

1.B.

5.2.2.2.2.C - Preparo das amostras 2 e 6

Foram transferidos $2,0 \mathrm{~mL}$ de cada amostra para balão volumétrico de $25 \mathrm{~mL}$, completando-se o volume com água desti lada. Desta solução, foram transferidos $5,0 \mathrm{~mL}$ para balão volumé trico de $100 \mathrm{~mL}$, completando-se o volume com $\mathrm{HCl}$ 0,1 $\mathrm{M}$.

5.2.2.2.2.D - Preparo das amostras 3 e 7

Foram transferidos 2,0 $\mathrm{mL}$ de cada amostra para balão volumétrico de $100 \mathrm{~mL}$, completando-se o volume com água destilada. Desta solução, transferiu-se uma alíquota de $5,0 \mathrm{~mL}$ para balão volumétrico de $100 \mathrm{~mL}$, completando-se o volume com $\mathrm{HCl} 0,1$ $\underline{M}$. 
$5.2 .2 .2 .2 . E-$ Procedimento

Para a reação seguiu-se o esquema mostrado no $\dot{i}-$ tem 5.2.2.2.1.F. Após homogeneização e repouso de trinta minu tos, os volumes foram completados com água destilada e as medi das de absorbância foram efetuadas a $615 \mathrm{~nm}$, contra o branco da reação. Foram efetuadas três determinações para o padrão e dez para cada amostra.

5.2 .2 .3 - TESTE DE RECUPERAÇÃO

5.2.2.3.A - Preparo do padrão

Foram pesados exatamente $100,0 \mathrm{mg}$ de cloridrato de ranitidina e transferidos para balão volumétrico de $250 \mathrm{~mL}$. Adicionou-se q.s. de água destilada pará dissolução e completou- se - volume com o mesmo solvente. Esta șolução continha 400,0 $\mu \mathrm{g}$ de cloridrato de ranitidina/mL.

5.2.2.3.B - Preparo das amostras 1, 4 e 5

Foram pesadas destas amostras quantidades que conti nham, teoricamente, $150,0 \mathrm{mg}$ de cloridrato de ranitidina e trans feridas para balões volumétricos de $100 \mathrm{~mL}$. Foram adicionados $30 \mathrm{~mL}$ de água destilada, agitando-se durante dez minutos. Os vo lumes foram completados com a mesmo solvente, filtrando-se, em seguida. Após rejeição dos primeiros $10 \mathrm{~mL}$ dos filtrados, foram transferidas alíquotas de $10,0 \mathrm{~mL}$ para balões volumétricos de 50 $\mathrm{mL}$, completando-se os volumes com água destilada.

5.2.2.3.C - Preparo das amostras 2 e 6

Foram transferidos 2,0 mL destas amostras para bạ 
lões volumétricos de $50 \mathrm{~mL}$, completando-se os volumes com água destilada. Destas soluções, foram transferidas alíquotas de $20,0 \mathrm{~mL}$ para balões volumétricos de $50 \mathrm{~mL}$, completando-se os vo lumes com o mesmo solvente.

5.2.2.3.D - Preparo das amostras 3 e 7

Foram transferidos 5,0 mL destas amostras para balões volumétricos de $100 \mathrm{~mL}$, completando-se os volumes com água destilada. Destas soluções, foram transferidas alíquotas de $10,0 \mathrm{~mL}$ para balões volumétricos de $50 \mathrm{~mL}$, completando-se os vo lumes com o mesmo solvente.

Para os testes foram transferidas alíquotas das amostras e do padrão para balões volumétricos de $50 \mathrm{~mL}$ (amostras 2 e 6 ) e de $100 \mathrm{~mL}$ (amostras 1, 3, 4, 5 e 7), segundo os esquemas abaixo:

\begin{tabular}{cc}
$\begin{array}{r}\text { Amostras } 2 \text { e } 6 \\
(\mathrm{~mL})\end{array}$ & $\begin{array}{c}\text { Padrão } \\
(\mathrm{mL})\end{array}$ \\
\hline- & 5,0 \\
5,0 & 1,0 \\
5,0 & 2,0 \\
5,0 & 5,0 \\
5,0 & - \\
\hline
\end{tabular}

\begin{tabular}{cc}
$\begin{array}{c}\text { Amostras } 1,3,4,5 \text { e } 7 \\
(\mathrm{~mL})\end{array}$ & $\begin{array}{c}\text { Padrão } \\
(\mathrm{mL})\end{array}$ \\
\hline- & 5,0 \\
10,0 & 1,0 \\
10,0 & 2,0 \\
10,0 & 5,0 \\
10,0 & - \\
\hline
\end{tabular}


5.2.2.3.E - Procedimento

Para a reação seguiu-se o esquema mostrado no ítem 5.2.2.2.1.F. Após homogeneização e repouso de trinta minutos, os volumes foram completados com água destilada e as medidas de absorbância foram efetuadas a $615 \mathrm{~nm}$, contra o branco da reação. As porcentagens de recuperação (\%R) foram calculadas pela expres são do ítem $5.2 \cdot 1.3$. 
6 - RESUltados -

6.1 - ESPECTROFOTOMETRIA NO ULTRAVIOLETA

o espectro de absorção do cloridrato de ranitidina no ultravioleta, em água destilada, encontra-se na figura 6.1.

6.1 .1 - PADRONIZAÇÃO DO MÉTODO

A curva de Ringbom construída a 313nm, em água destị lada, encontra-se na figura 6.2 .

Os valores experimentais de absorbância para construa ção da reta de calibração são encontrados na tabela 6.1 .

Os resultados do tratamento estatístico sobre os valores experimentais utilizados para construção da reta de cali bração são encontrados na tabela 6.2 , e foram baseados no método dos mínimos quadrados (análise estatística, pg.74).

A reta de calibração obtida é mostrada na figura 6.3.

6.1.2 - APLICAÇÃO DO MÉTODO PADRONIZADO A AMOSTRAS COMERCIAIS E SIMULADAS

6.1.2.1 - PESQUISA DE INTERFERÊNCIA A PARTIR DOS EXCIPIENTES

A figura 6.4 apresenta a comparação entre os espectros de absorção do padrão $P$, das amostras 1 e 5, e do placebo da amostra 5 .

A figura 6.5 apresenta a comparação entre os espectros de absorção do padrão $P$ e da amostra 4 . 
A figura 6.6 apresenta a comparação entre os espectros de absorção da amostra 2 e da amostra 6 .

A figura 6.7 apresenta a comparação entre os espectros de absorção da amostra 2; do padrão $\mathrm{P}_{1}$ e do placebo da amostra 6 .

A figura 6.8 apresenta a comparação entre os espectros de absorção da amostra 3 e da amostra 7 .

A figura 6.9 apresenta a comparação entre os espectros de absorção da amostra 3 , do padrão $\mathrm{P}_{2}$, da amostra 7 e do placebo da $\mathrm{a}=$ mostra 7 .

6.1.2.2 - DETERMINAÇÃO DO TEOR DE CLORIDRATO DE RANITIDINA NAS $\underline{\text { A }}$ MOSTRAS COMERCIAIS $(1,2,3$ e 4) E SIMULADAS $(5,6$ e 7)

A tabela 6.3 apresenta os resultados obtidos da análise das amostras comerciais e simuladas.

o tratamento estatístico dos valores experimentais obtidos encon tram-se na tabela 6.4 (Análise estatística, pg 78 ).

6.1 .3 - TESTE DE RECUPERAÇÃO

Os resultados do teste de recuperação efetuado nas amostras comerciais e simuladas são encontrados na tabela 6.5 . 
45

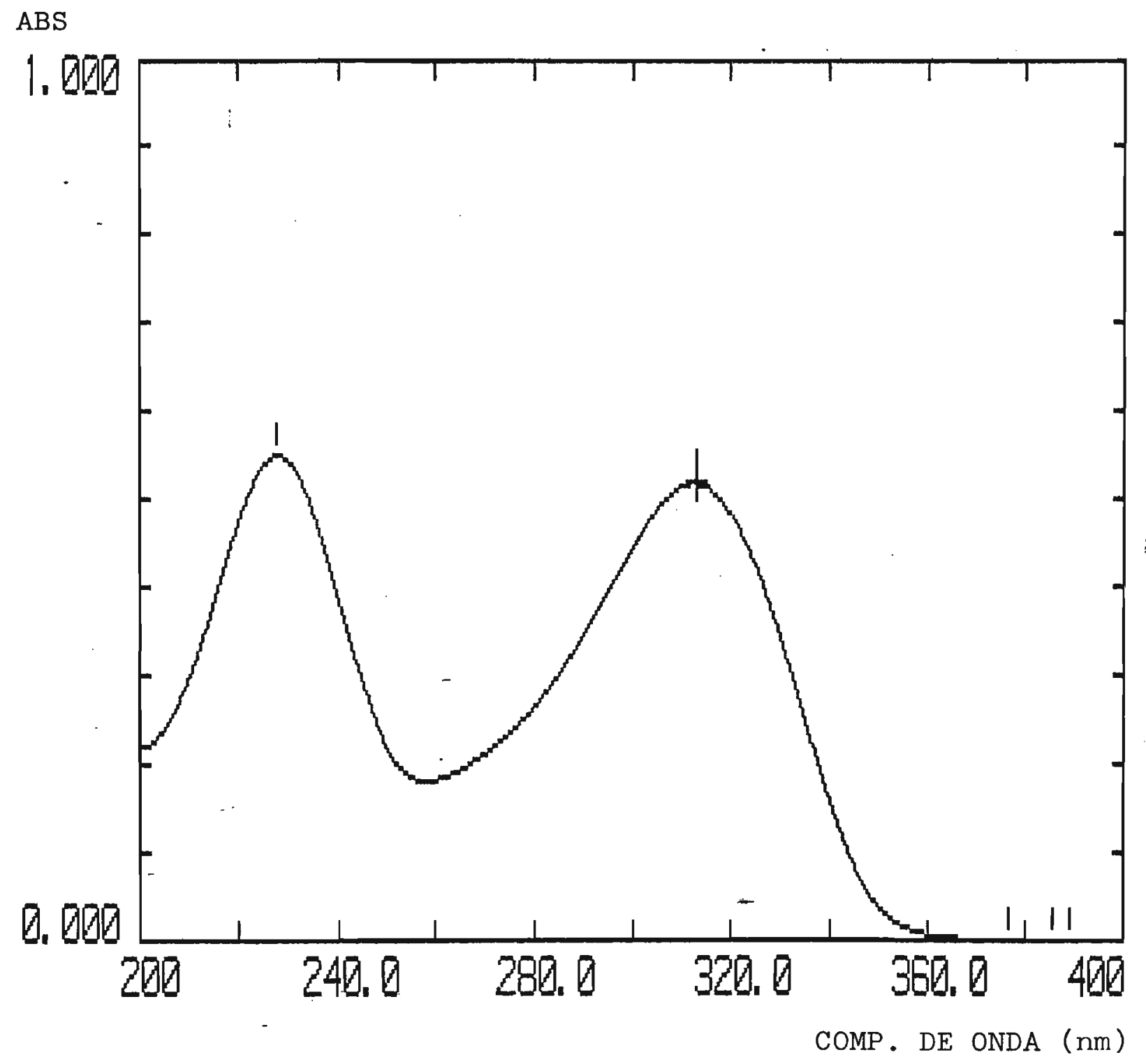

Figura 6.1 - Espectro de absorção no ultravioleta do cloridrato de ranitidina em água destilada $(12,0 \mu \mathrm{g} / \mathrm{mL})$. 


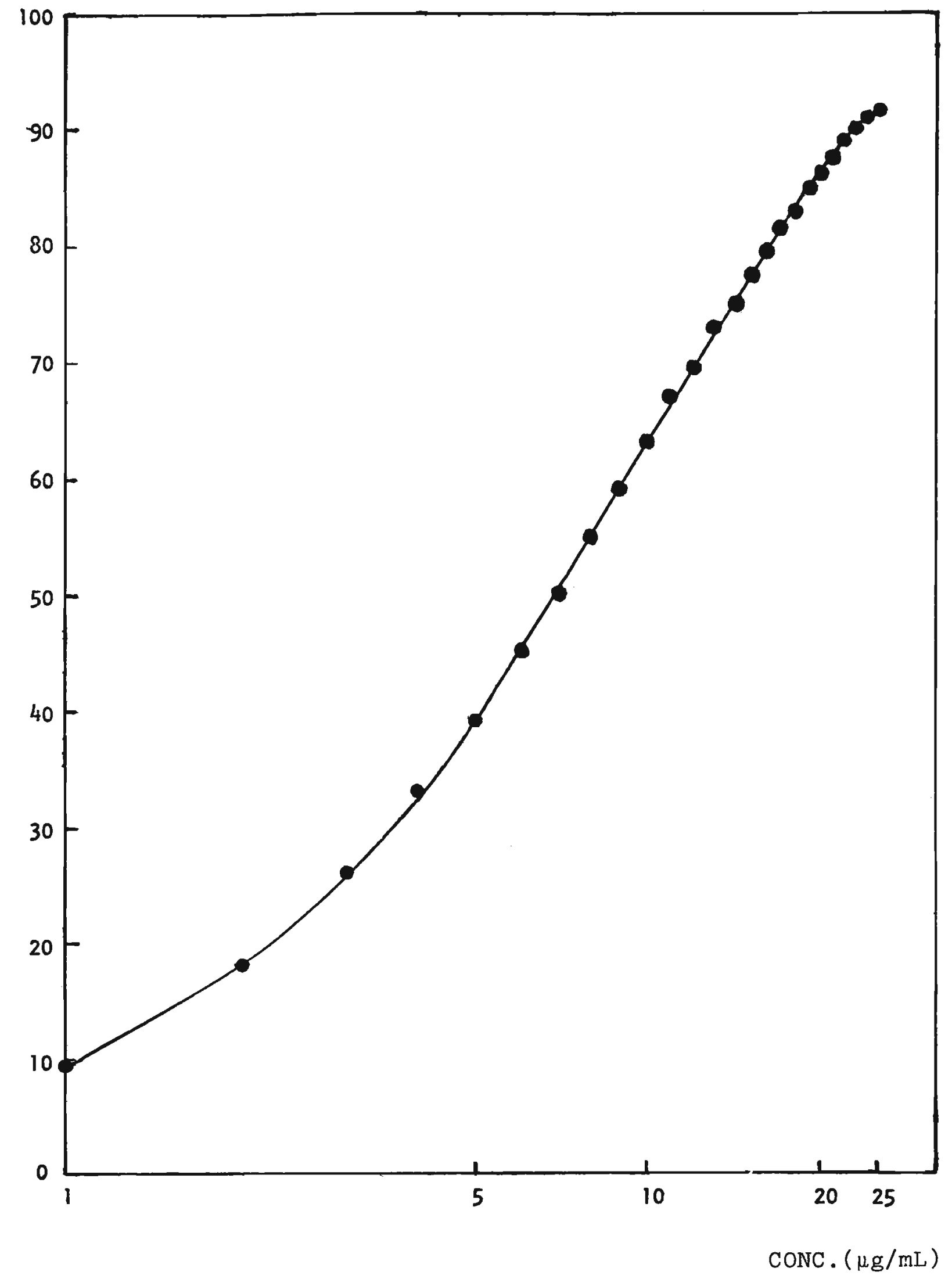

Figura 6.2 - Curva de Rinbgom obtida pelo método espectrofotométrico no ultravioleta para o cloridrato de ranitidi na.

Concentração das soluções: 1,0 a $25,0 \mu \mathrm{g} / \mathrm{mL}$. Leituras efetuadas a $313 \mathrm{~nm}$. 
Tabela 6.1 - Resultados experimentais obtidos na determinação da reta de calibração do método espectrofotométrico no ultravioleta para o cloridrato de ranitidina. Leitú ras efetuadas a $313 \mathrm{~nm}$.

Concentração de

Absorbância

leitura $(\mu \mathrm{g} / \mathrm{mL})$
0,2169
0,3036
0,3454
0,4321
0,4762
0,5159
0,6038
0,6456
0,6896
0,7757

5,0

8,0

10,0

11,0

12,0

14,0

15,0

16,0

18,0

Tabela 6.2 - Resultados estatísticos referentes à reta de cali bração do método espectrofotométrico no ultravioleta.

Inclinação da reta (b)

0,0431

Coeficiente de correlação ( $r$ )

0,9999

Erro padrão relativo de estimativa ( $\mathrm{Se}_{\mathrm{r}}$ )

. $0,20 \%$ 


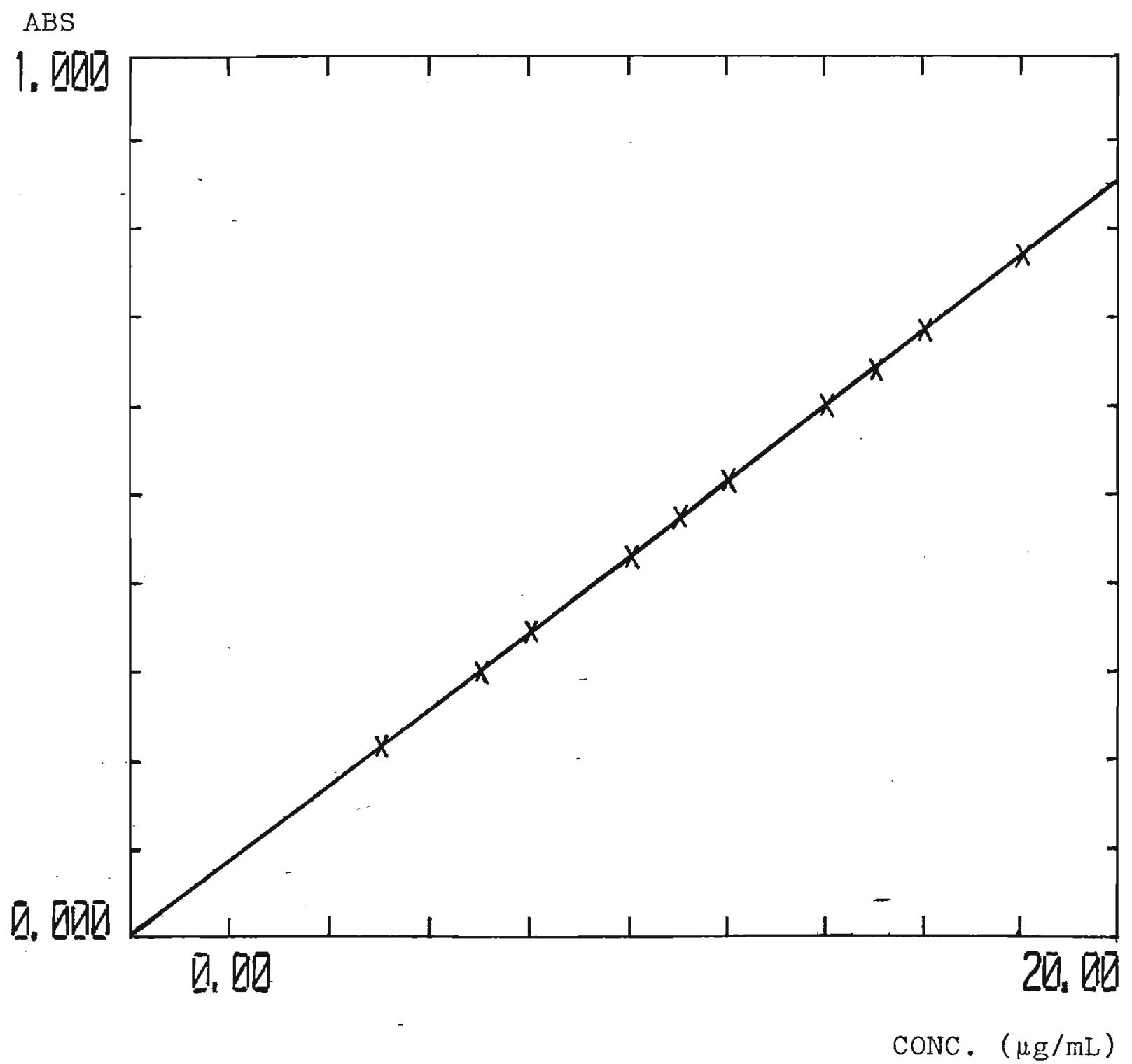

Figura 6.3 - Reta de calibração do cloridrato de ranitidina em água destilada.

Método: Espectrofotometria no ultravioleta.

Leituras efetuadas a $313 \mathrm{~nm}$. 


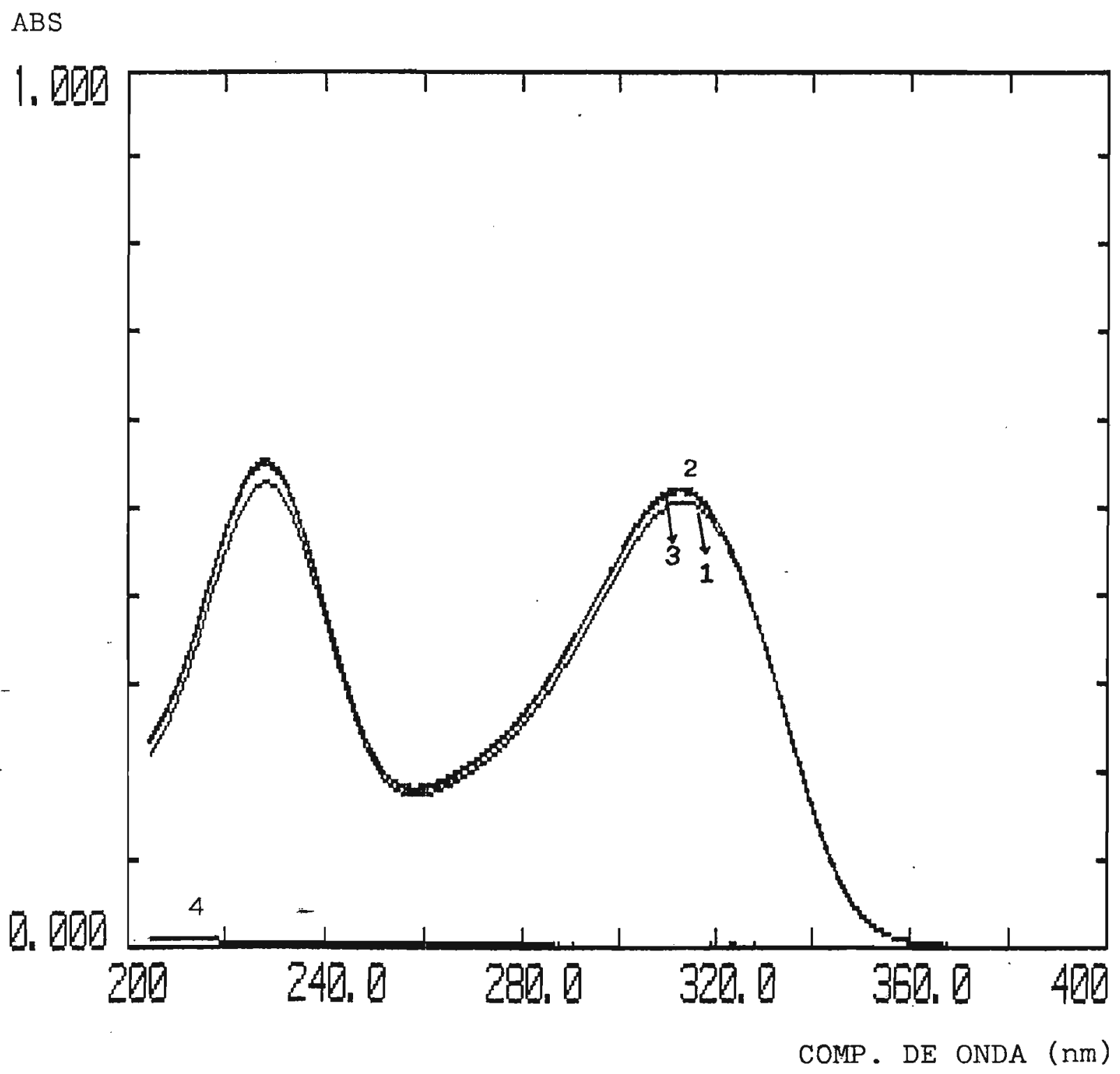

Figura 6.4 - Comparação entre os espectros de absorção:

$$
\begin{aligned}
& 1 \text { - Amostra } 1 \\
& 2 \text { - Amostra } 5 \text { (simulada) } \\
& 3 \text { - Padrão P } \\
& 4 \text { - Placebo da amostra } 5
\end{aligned}
$$




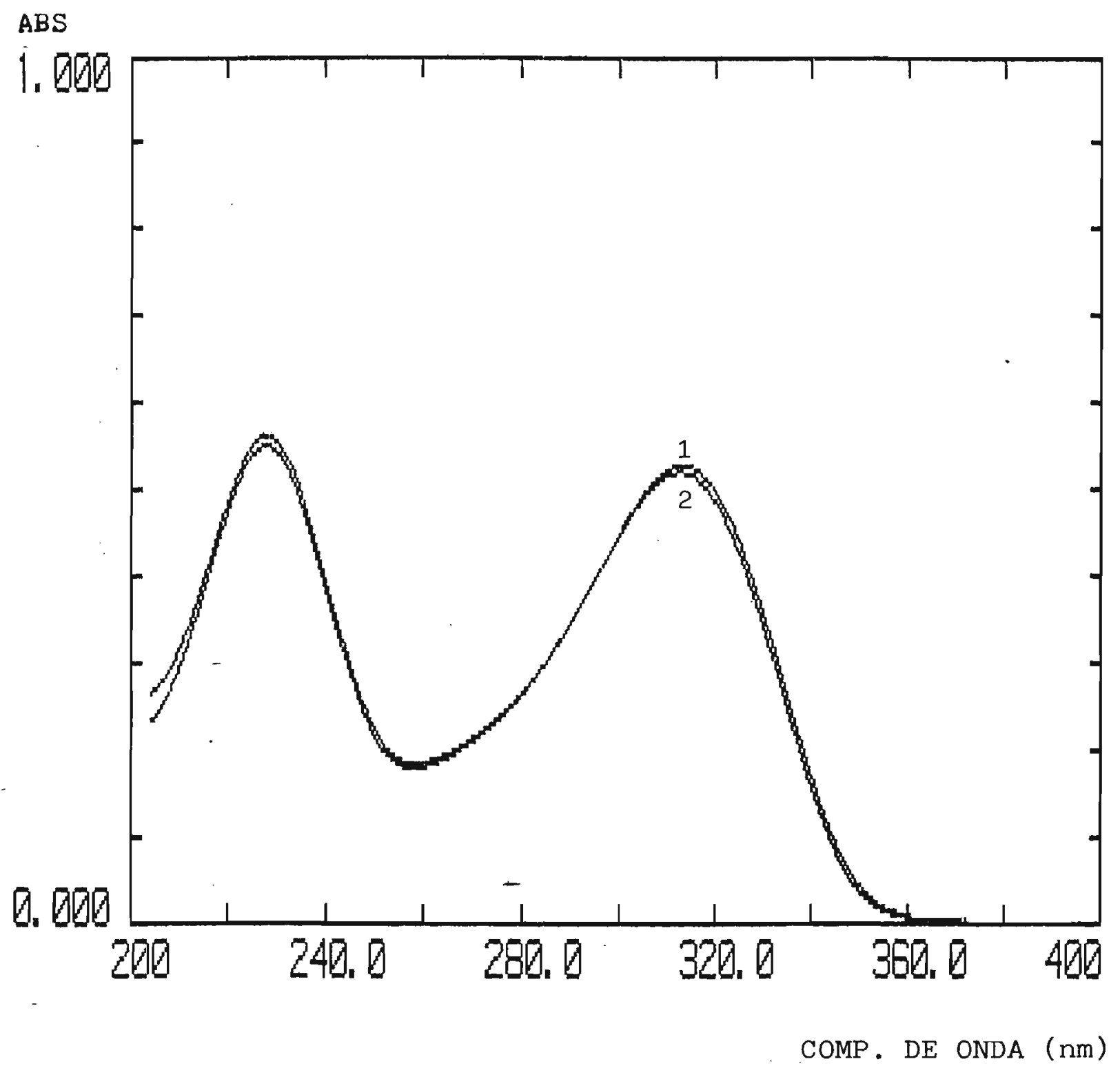

Figura 6.5 - Comparação dos espectros de absorção:

$$
\begin{aligned}
& 1 \text { - Amostra } 4 \\
& 2 \text { - Padrão P }
\end{aligned}
$$




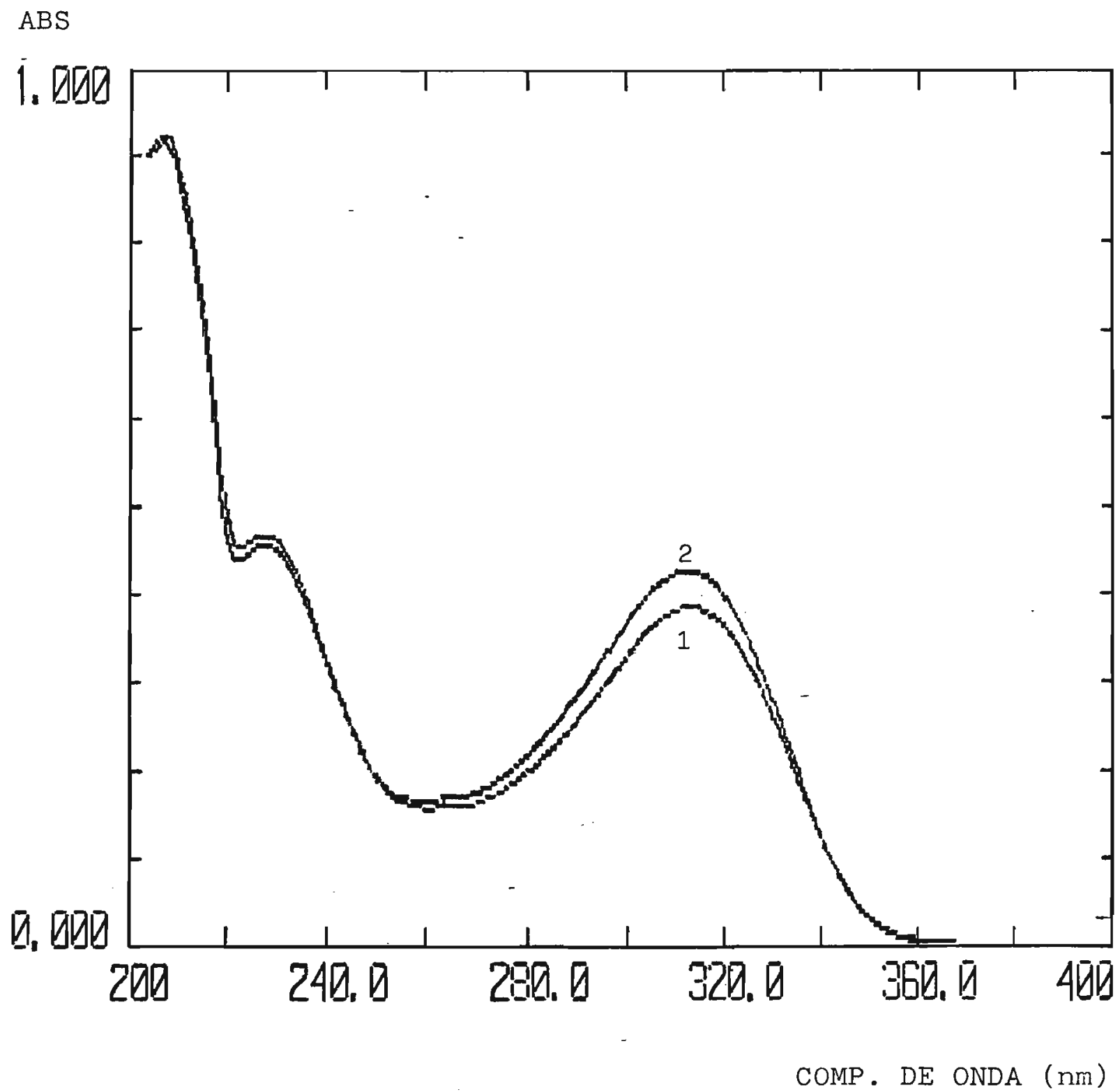

Figura 6.6 - Comparação entre os espectros de absorção: 1 - Amostra 2 2 - Amostra 6 (simulada) 
52

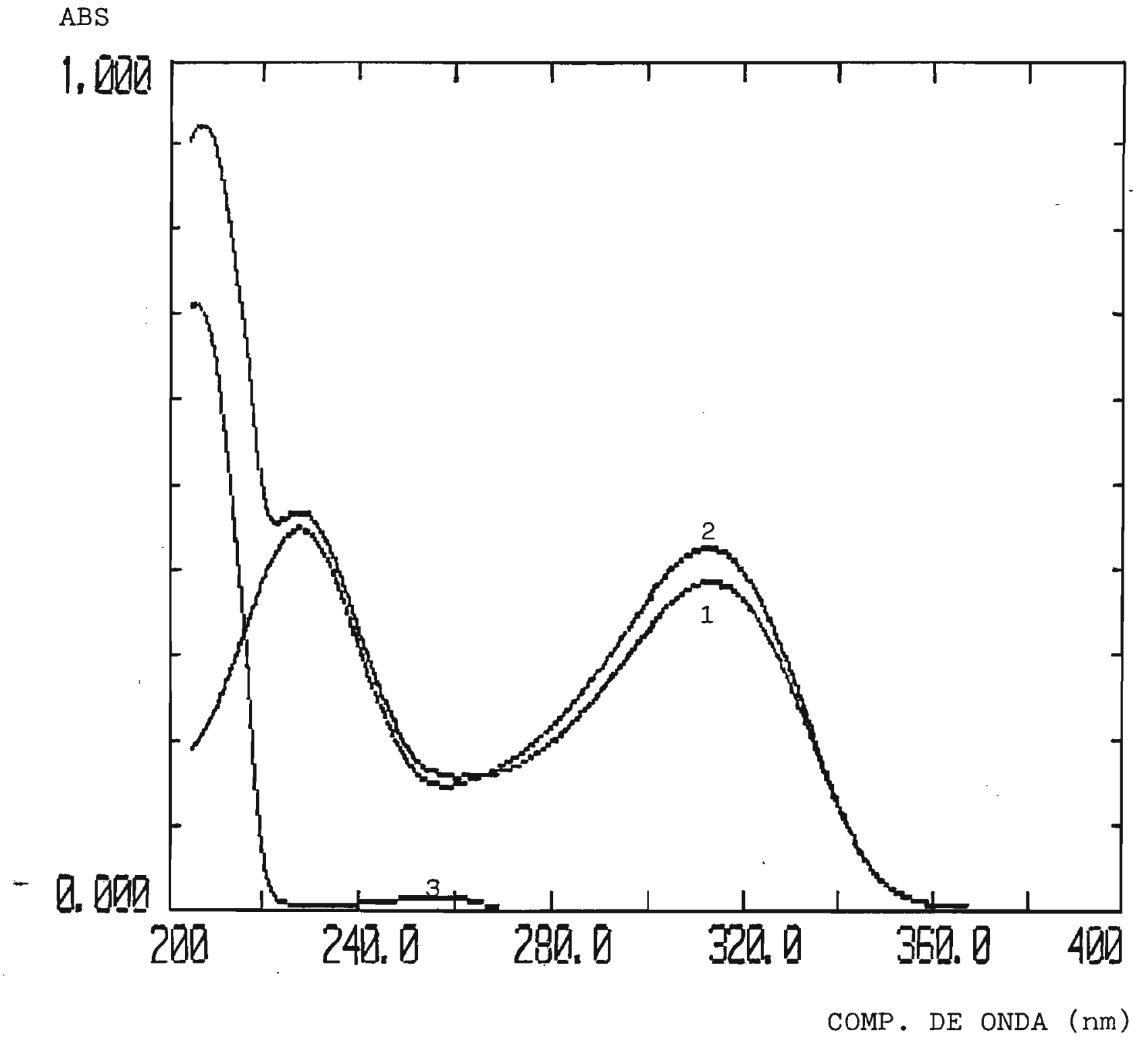

Figura 6.7 - Comparação entre os espectros de absorção:

$$
\begin{aligned}
& 1 \text { - Amostra } 2 \\
& 2 \text { - Padrão } P_{1} \\
& 3 \text { - Placebo da amostra } 6
\end{aligned}
$$




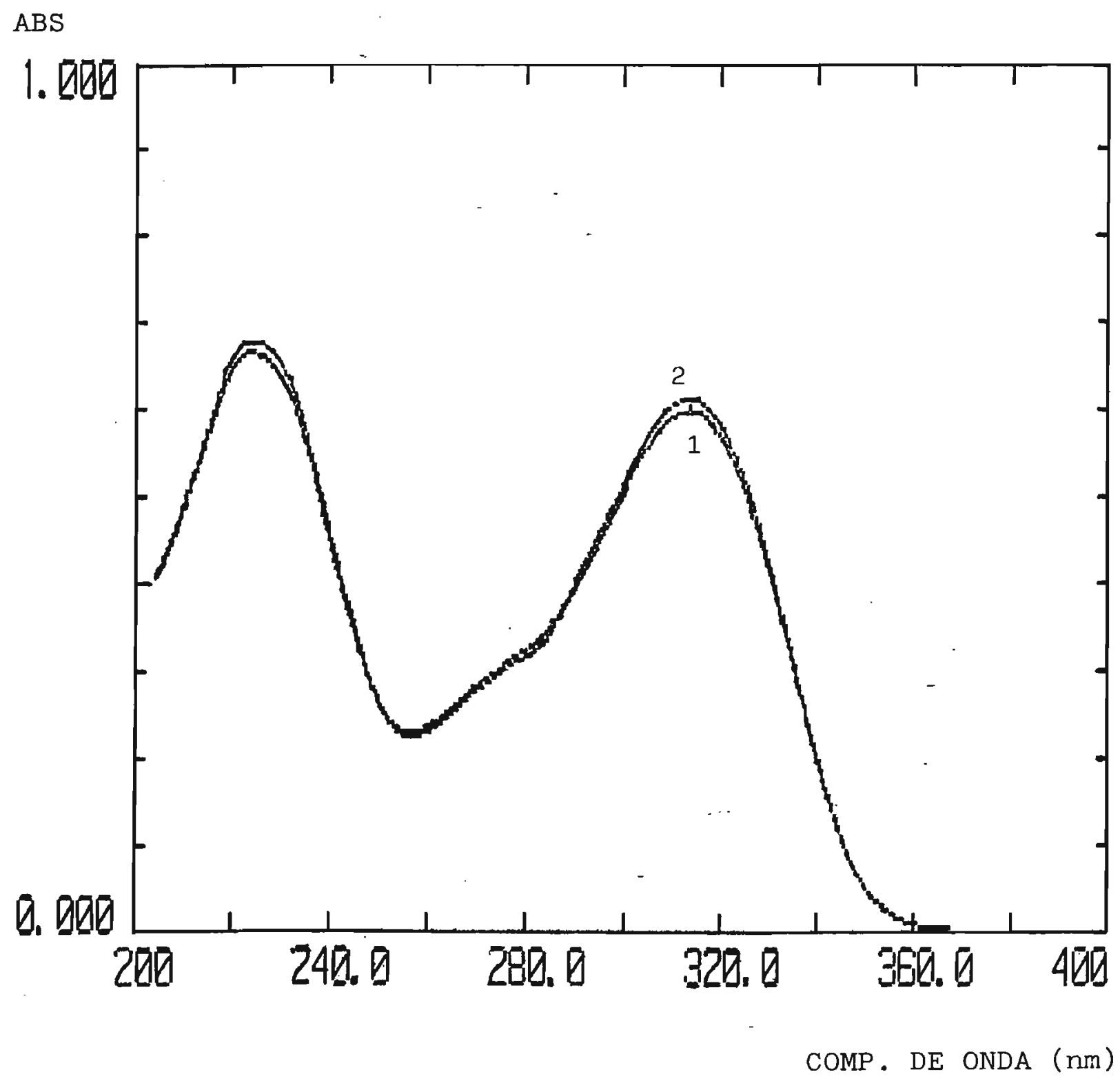

Figura 6.8 - Comparação entre os espectros de absorção: 1 - Amostra 3

2 - Amostra 7 (simulada) 


\section{ABS}

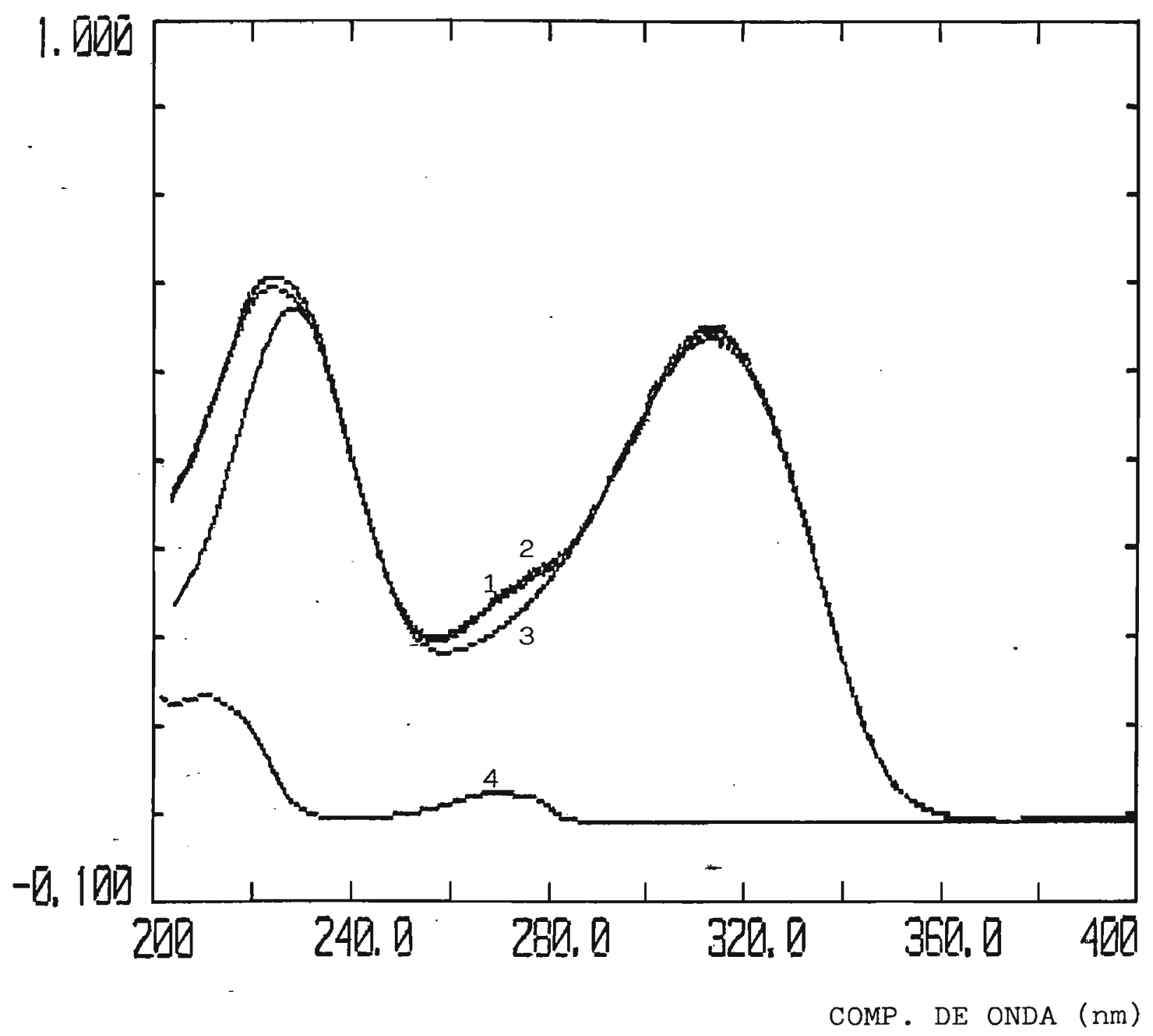

Figura 6.9 - Comparação entre os espectros de absorção:

$$
\begin{aligned}
& 1 \text { - Amostra } 3 \\
& 2 \text { - Amostra } 7 \text { (simulada) } \\
& 3 \text { - Padrão P } 2 \text { da amostra } 7 \\
& 4 \text { - Placebo }
\end{aligned}
$$


Tabela 6.3 - Resultados obtidos na determinação do teor de clori drato de ranitidina em anostras comerciais e simula das, utilizando-se o método espectrofotométrico no ultravioleta.

\begin{tabular}{cccc}
\hline $\begin{array}{c}\text { Amostra } \\
\mathrm{n} \text { o }\end{array}$ & $\begin{array}{l}\text { Valor rotulado de } \\
\text { cloridrato de ra- } \\
\text { nitidina }\end{array}$ & $\begin{array}{l}\text { Valor encontrado } \\
\text { de cloridrato de } \\
\text { ranitidina* }\end{array}$ & $\begin{array}{c}\text { Teor } \\
\text { percentual } \\
(\%)\end{array}$ \\
\hline & & & \\
1 & 150, OOmg/comp. & $143,54 \mathrm{mg} / \mathrm{comp}$. & 95,69 \\
2 & 50, OOmg/5mL & $44,44 \mathrm{mg} / 5 \mathrm{~mL}$ & 88,88 \\
3 & 56, OOmg/2mL & $56,64 \mathrm{mg} / 2 \mathrm{~mL}$ & 101,15 \\
4 & $167,40 \mathrm{mg} / \mathrm{comp}$. & $164,84 \mathrm{mg} / \mathrm{comp}$. & 98,47 \\
5 & $150,00 \mathrm{mg} / \mathrm{comp}$. & $150,36 \mathrm{mg} / \mathrm{comp}$. & 100,24 \\
6 & $50,00 \mathrm{mg} / 5 \mathrm{~mL}$ & $50,01 \mathrm{mg} / 5 \mathrm{~mL}$ & 100,02 \\
7 & $56,00 \mathrm{mg} / 2 \mathrm{~mL}$ & $56,01 \mathrm{mg} / 2 \mathrm{~mL}$ & 100,02 \\
\hline
\end{tabular}

* Média de dez determinações.

Tabela 6.4 - Resultados estatísticos obtidos na determinação do teor de cloridrato de ranitidina em amostras comer ciais e simuladas.

\begin{tabular}{lcr}
\hline $\begin{array}{c}\text { Amostra } \\
n \underline{0}^{-}\end{array}$ & $\begin{array}{l}\text { Coeficiente de } \\
\text { variação }(\%)\end{array}$ & $\begin{array}{l}\text { Intervalo de confiança } \\
\text { da média }\end{array}$ \\
\hline 1 & 0,36 & $95,69 \pm 0,25$ \\
2 & 0,51 & $88,88 \pm 0,32$ \\
3 & 0,24 & $101,15 \pm 0,17$ \\
4 & 0,71 & $98,47 \pm 0,50$ \\
5 & 0,84 & $100,24 \pm 0,60$ \\
6 & 0,23 & $100,02 \pm 0,17$ \\
7 & 0,20 & $100,01 \pm 0,14$ \\
\hline
\end{tabular}


Tabela 6.5 - Resultados do teste de recuperação realizado nas a mostras comerciais e simuladas, utilizando-se o mé todo espectrofotométrico no ultravioleta.

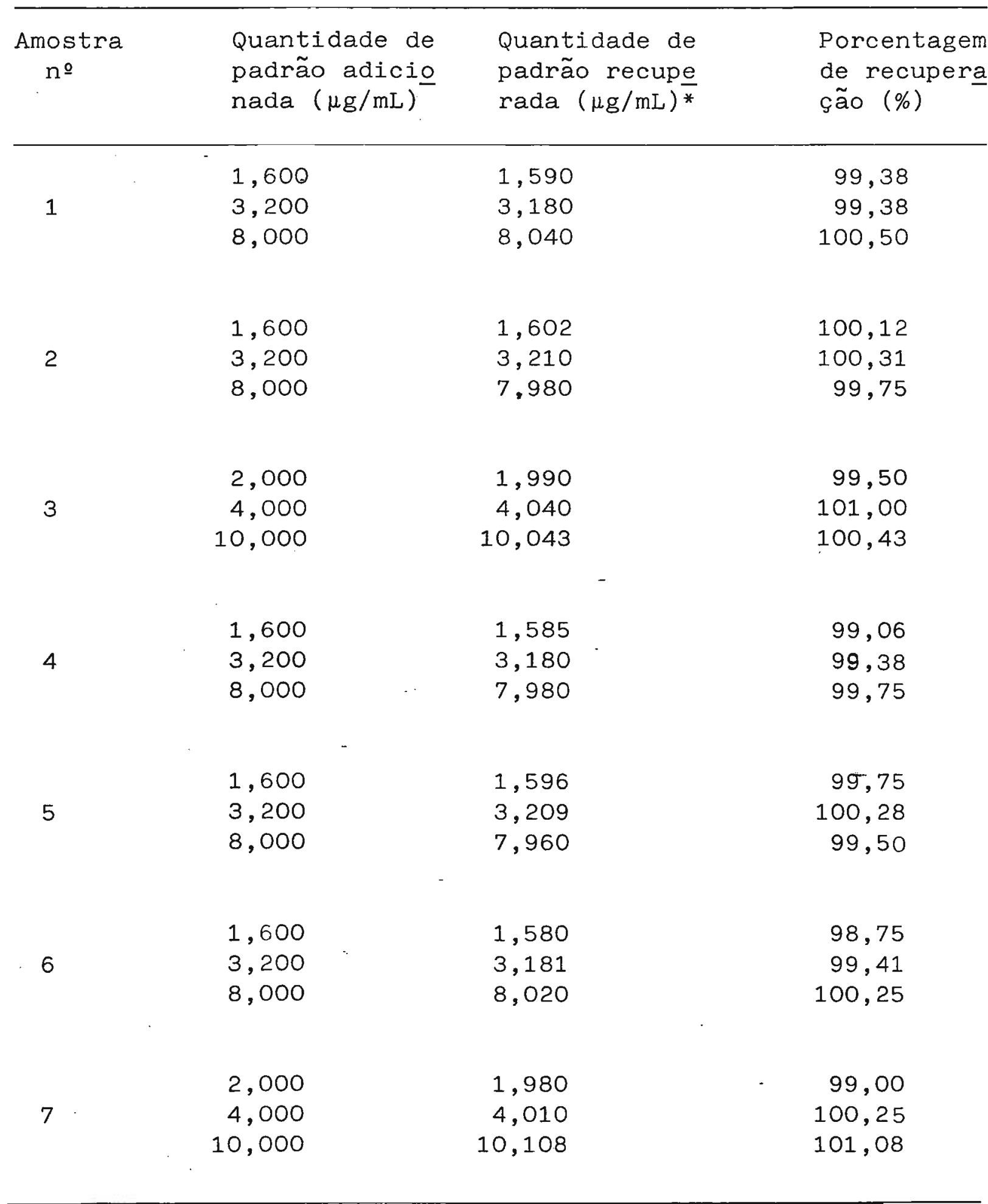

* Média de duas determinações. 
6.2 - ESPECTROFOTOMETRIA NO VISÍVEL

6.2 .1 - PADRONIZAÇÃO DO MÉTODO

A figura 6.10 mostra, reunidas em um mesmo gráfico, as curvas obtidas das medidas de absorbância relativas à variação da concentração das soluções de MBTH e cloreto férrico.

A tabela 6.6 mostra os valores de absorbância quando fo ram variadas as concentrações de $\mathrm{HCl}$ e também quando se utili zou água destilada como solvente.

A figura 6.11 mostra o desenvolvimento da reação através do tempo ( de zero a quarenta e cinco minutos).

A tabela 6.7 mostra os valores de absorbância obtidos quando se adicionou água destilada logo após a adição dos reagentes e trinta minutos após a adição dos mesmos.

A figura 6.12 mostra o comportamento da reação após a a dição de água destiladá, através das medidas de absorbância durante cento e vinte minutos contados a partir do periodo de repouso de trinta minutos.

A figura 6.13 mostra a obtenção da relação estequiomé trica entre o cloridrato de ranitidina e o $\mathrm{MBTH}$, através da pró jeção da medida de absorbância máxima até o eixo das abscissas do gráfico.

A figura 6.14 mostra o espectro de absorção do produto colorido formado na reação, traçado de 700 a $400 \mathrm{~nm}$.

A figura 6.15 mostra a curva de Ringbom construída a $615 \mathrm{~nm}$. 
Os valores experimentais de absorbância para construção da reta de calibração são encontrados na tabela 6.8 . Os resultados do tratamento estatístico sobre os valores experi mentais utilizados para construção da reta de calibração são en contrados na tabela 6.9.

A reta de calibração obtida é mostrada na figura 6.16 .

6.2.2 - APLICAÇ̃̃O DO MÉTODO PADRONIZADO A AMOSTRAS COMERCIAIS E SIMULADAS

6.2.2.1 - PESQUISA DE INTERFERÊNCIA A PARTIR DOS EXCIPIENTES

A figura 6.17 apresenta a comparação entre os es pectros de absorção da reação a partir da amostra 1 , do padrão e do placebo da amostra 5 .

A figura 6.18 apresenta a comparação entre os es pectros de absorção da reação a partir da amostra 2, do padrão e do placebo da amostra 6 .

A figura 6.19 apresenta a comparação entre os es pectros de absorção da reação a partir da amostra 3 , do padrão e do placebo da amostra 7 .

A figura 6.20 apresenta a comparação entre os es pectros de absorção da reação a partir da amostra $4^{-}$e do pạ drão.

6.2.2.2 - DETERMINAÇÃO DO TEOR DE CLORIDRATO DE RANITIDINA NAS AMOSTRAS COMERCIAIS $(1,2,3$ e 4) E SIMULADAS $(5, \cdot 6$ e 7)

A tabela 6.10 apresenta os resultados obtidos da aná- 
lise das amostras comerciais e simuladas.

O tratamento estatístico dos valores experimentais obtidos encon tram-se na tabela 6.11 .

6.2 .3 - TESTE DE RECUPERAÇÃO

Os resultados do teste de recuperação efetuado nas amostras comerciais e simuladas, utilizando-se o método espectrofoto métrico no visível, são encontrados na tabela 6.12 . 


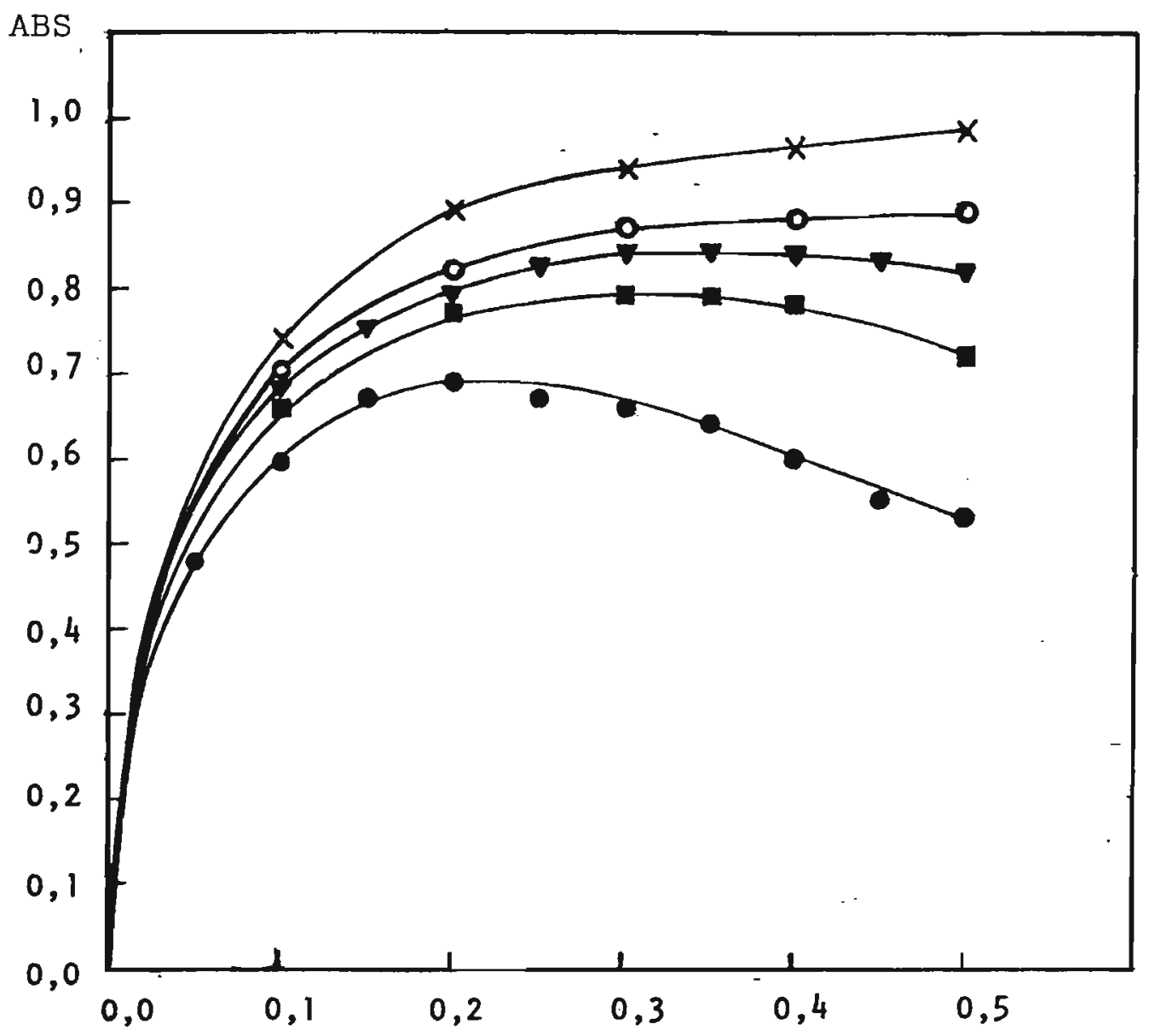

CONC. DE MBTH (\%)

Figura 6.10 - Determinação das concentrações ótimas de MBTH e cloreto férrico.

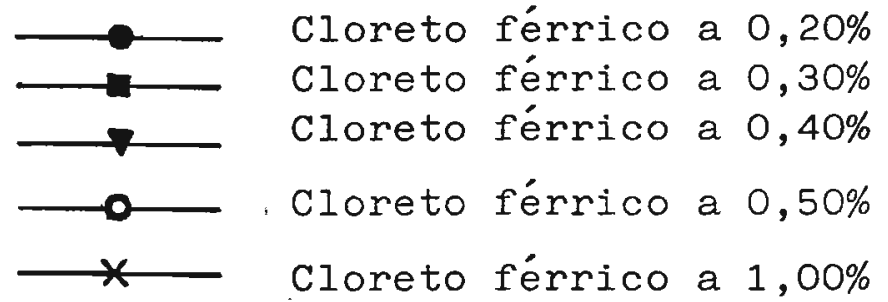


Tabela 6.6 - Influência da concentração de HCl como solvente da reação.

\begin{tabular}{ll} 
Solvente & Abs a $615 \mathrm{~nm}$ \\
\hline Água destilada & 0,1654 \\
$\mathrm{HCl} 0,01 \underline{\mathrm{M}}$ & 0,5131 \\
$\mathrm{HCl} 0,1 \mathrm{M}$ & 0,5225 \\
$\mathrm{HCl} 1,0 \mathrm{M}$ & 0,5718
\end{tabular}

ABS

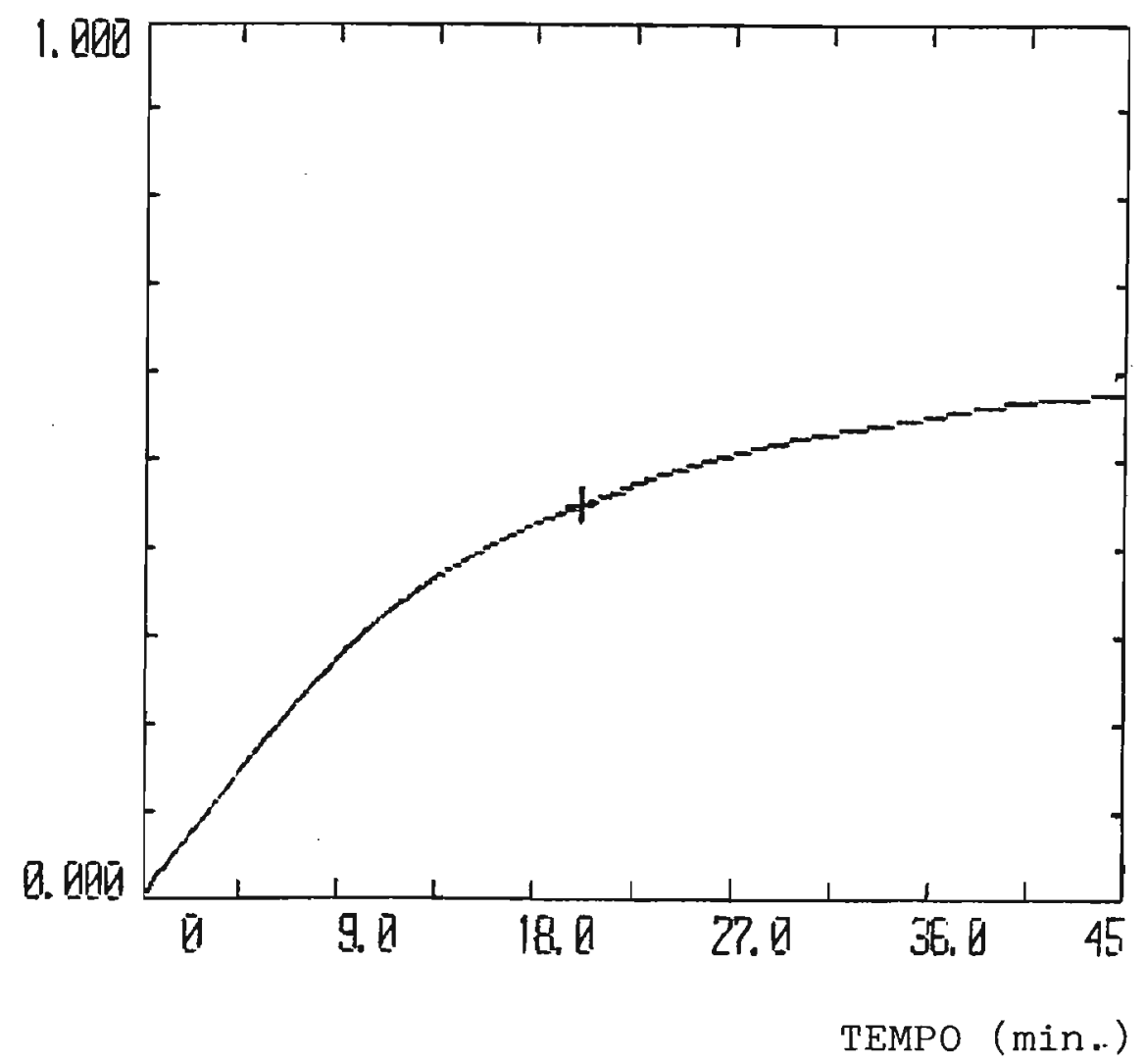

Figura 6.11 - Determinação do tempo necessá rio para a estabilização da rea ção. 
Tabela 6.7 - Influência da adição de água na estabilização da reação.

Abs a $615 \mathrm{~nm}$

Adição de água logo após

a adição dos reagentes

0,1575

Adição de água trinta mí nutos após a adição dos reagentes

0,4997

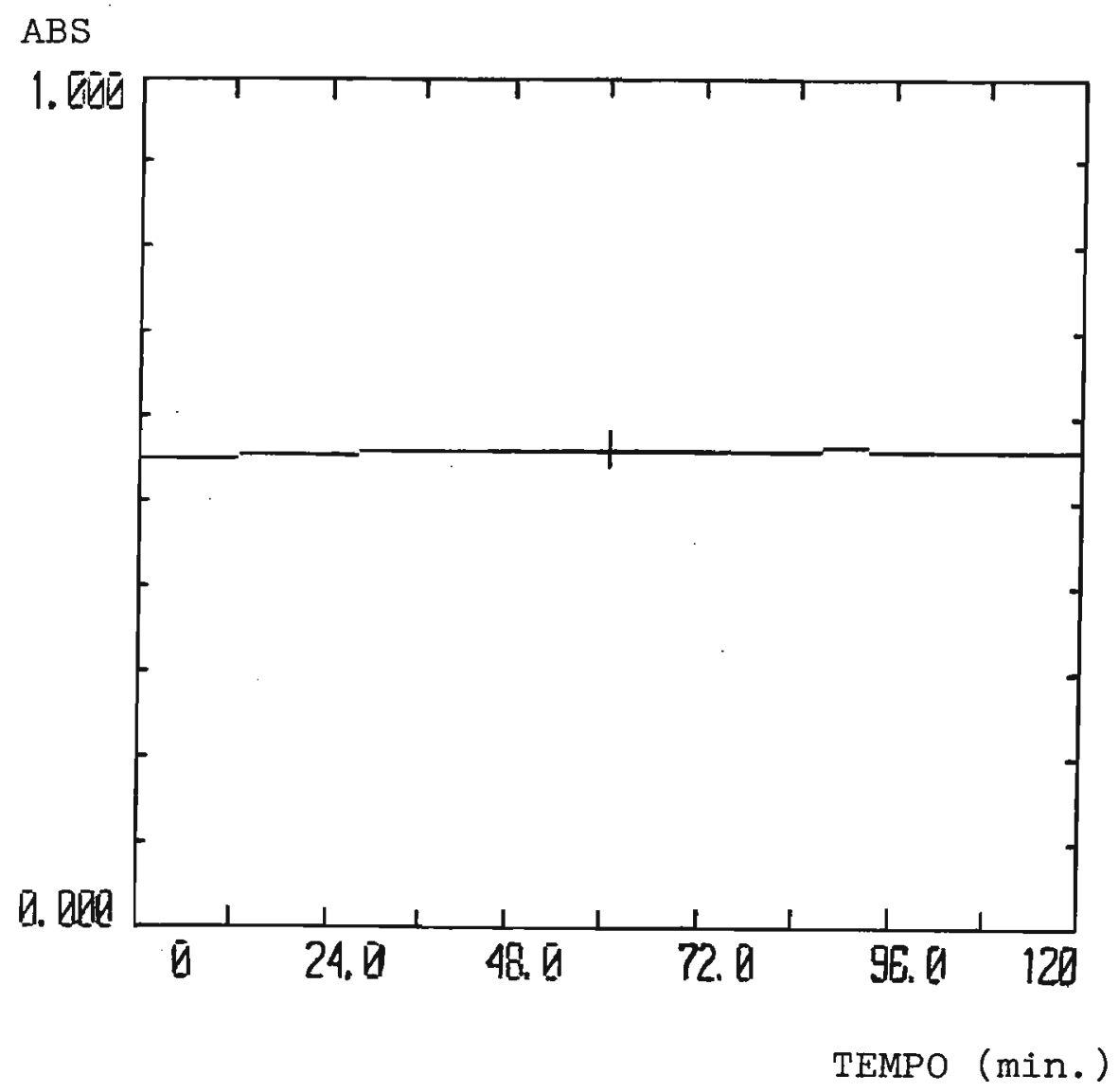

Figura 6.12 - Determinação do tempo de estabiIidade da reação. 
ABS

$\times 100$

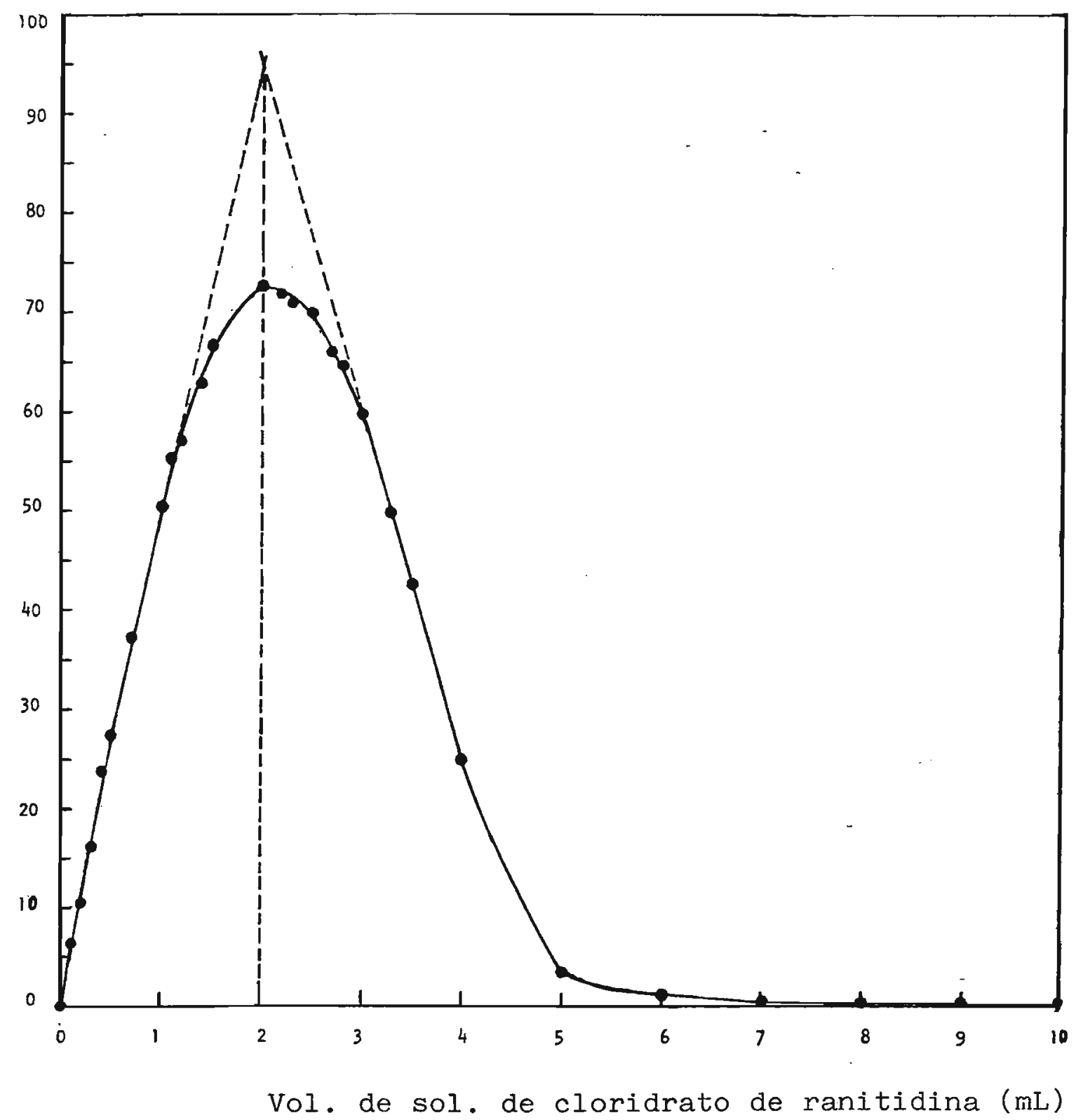

Figura 6.13 - Determinação da relação estequiométrica entre o cloridrato de ranitidina e o MBTH. 


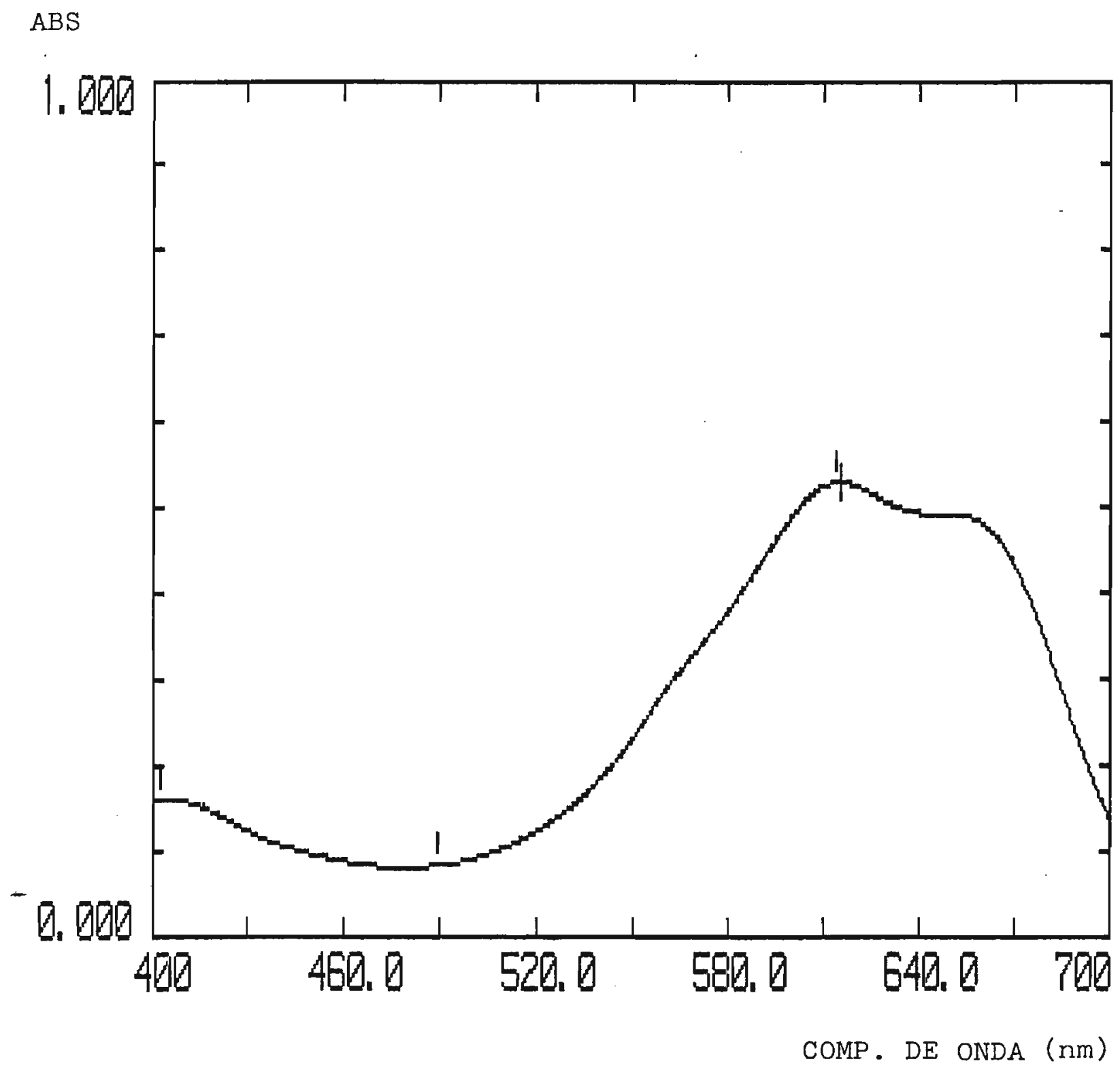

Figura 6.14 - Espectro de absorção do produto colorido formado através da reação entre o cloridrato de ranitidina e o MBTH, em presença de cloreto férrico. 
100-T

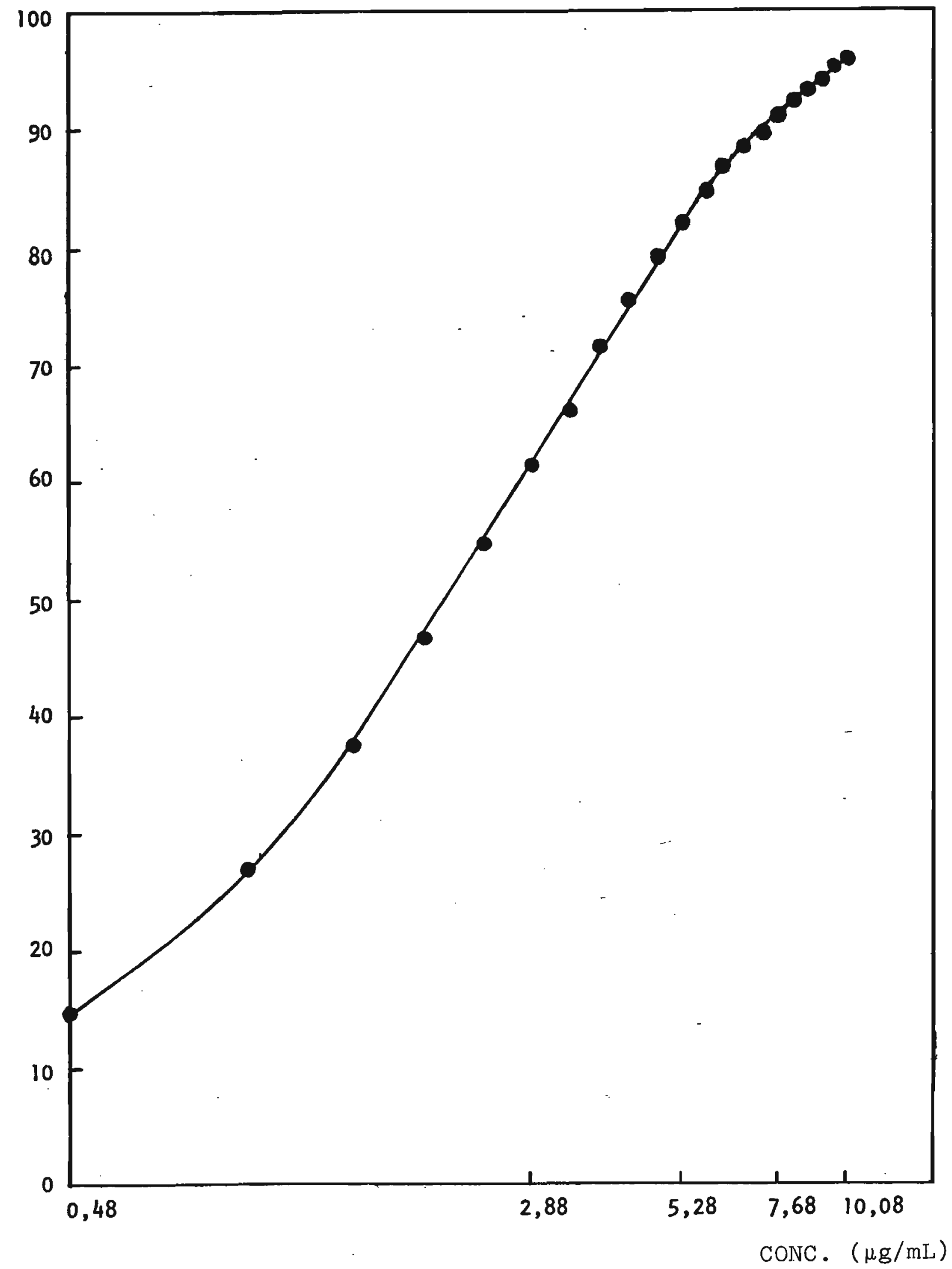

Figura 6.15 - Curva de Ringbom obtida pelo método espectrofotomé trico no visivel para o cloridrato de ranitidina. Concentração das soluções: 0,48 a $10,08 \mu \mathrm{g} / \mathrm{mL}$. Leituras efetuadas a $615 \mathrm{~nm}$. 
Tabela 6.8 - Resultados experimentais obtidos na determinação da reta de calibração do método espectrofotométrico no visível para o cloridrato de ranitidina. Leituras $\underline{e}$ fetuadas a $615 \mathrm{~nm}$.

\begin{tabular}{cc}
$\begin{array}{c}\text { Concentração de } \\
\text { leitura }(\mu \mathrm{g} / \mathrm{mL}) \\
\cdot\end{array}$ & Absorbância \\
\hline 1,44 & 0,2041 \\
1,92 & 0,2723 \\
2,40 & 0,3409 \\
2,88 & 0,4117 \\
3,36 & 0,4687 \\
3,84 & 0,5465 \\
4,32 & 0,6104 \\
4,80 & 0,6798 \\
5,28 & 0,7467 \\
5,76 & 0,8084 \\
\hline
\end{tabular}

Tabela 6.9 - Resultados estatísticos referentes à reta de cali bração do método espectrofotométrico no visível.

Inclinação da reta (b)

0,1413

Coeficiente de correlação ( $r$ )

0,9999

Erro padrão relativo de estimativa ( $\mathrm{Se}_{r}$ )

$0,69 \%$ 
ABS

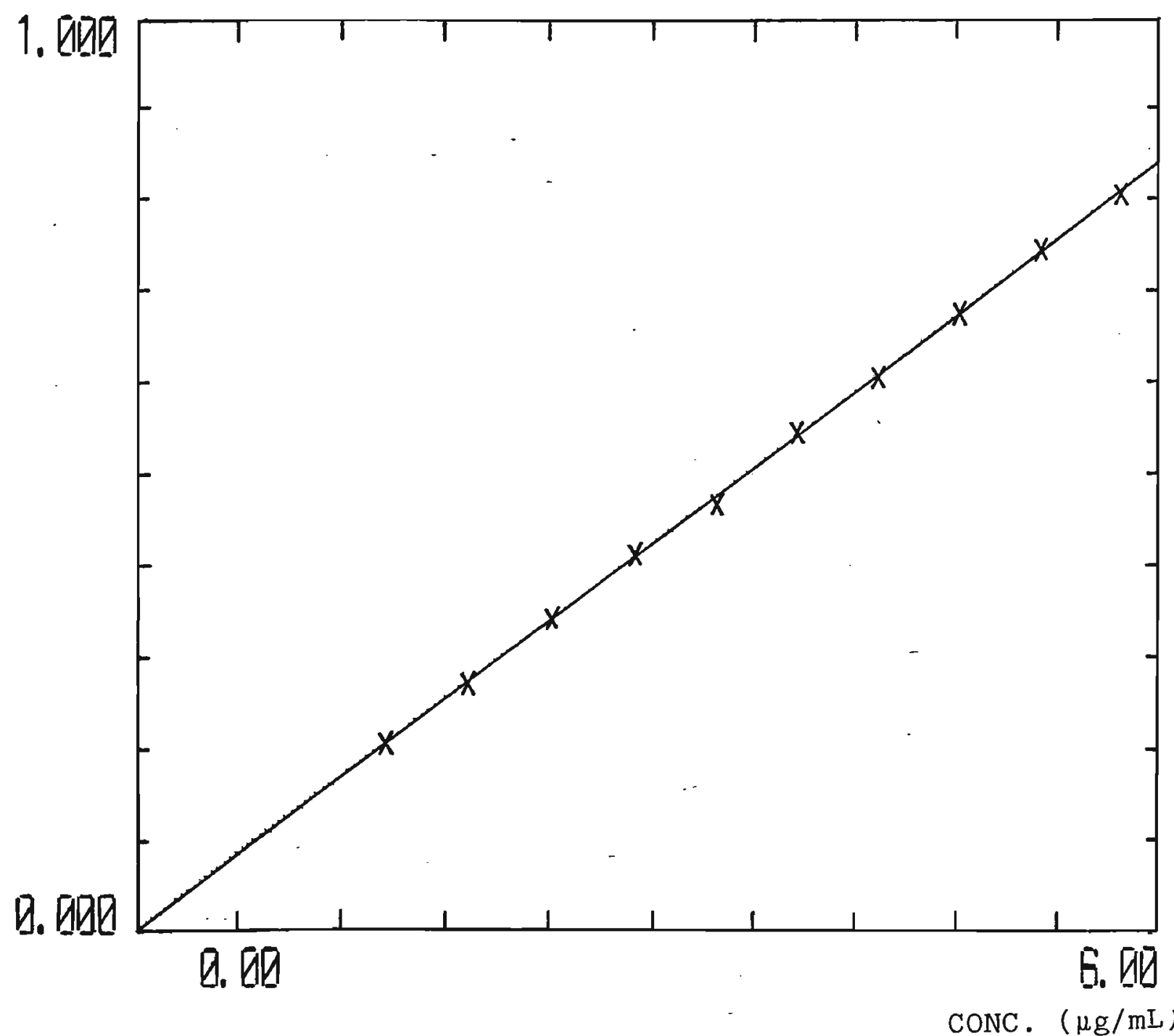

Figura 6.16 - Reta de calibração do método espectrofotométrico no visível.

Leituras efetuadas a $615 \mathrm{~nm}$. 


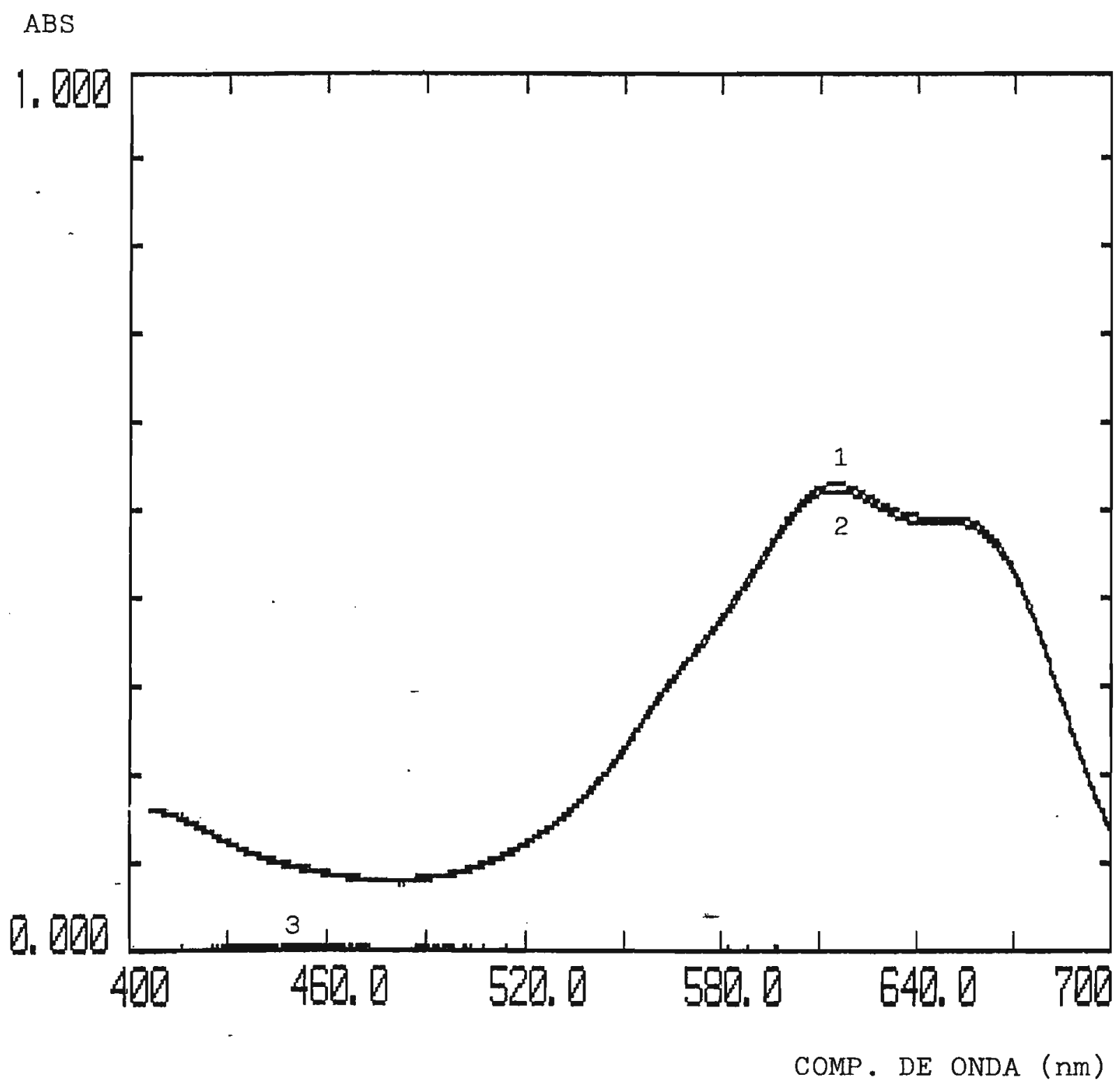

Figura 6.17 - Comparação entre os espectros de absorção no visivel:

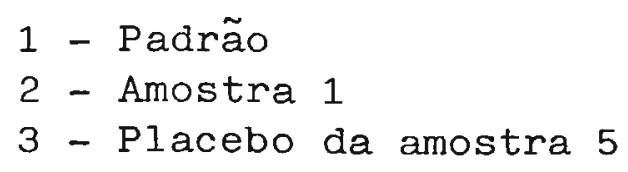




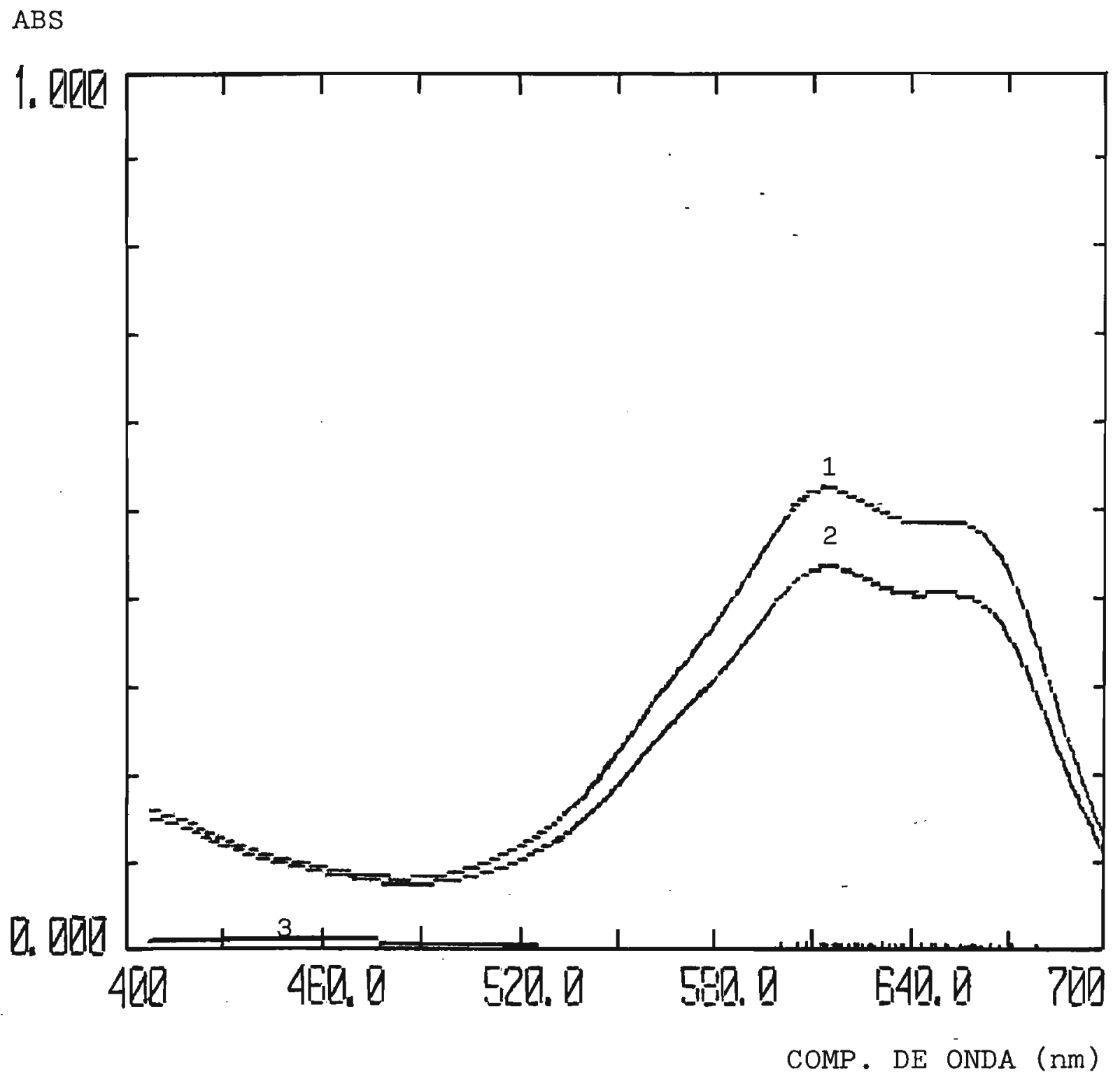

Figura 6.18 - Comparação entre os espectros de absorção no visível:

$$
\begin{aligned}
& 1 \text { - Padrão } \\
& 2 \text { - Amostra } 2 \\
& 3 \text { - Placebo da amostra } 6
\end{aligned}
$$


ABS

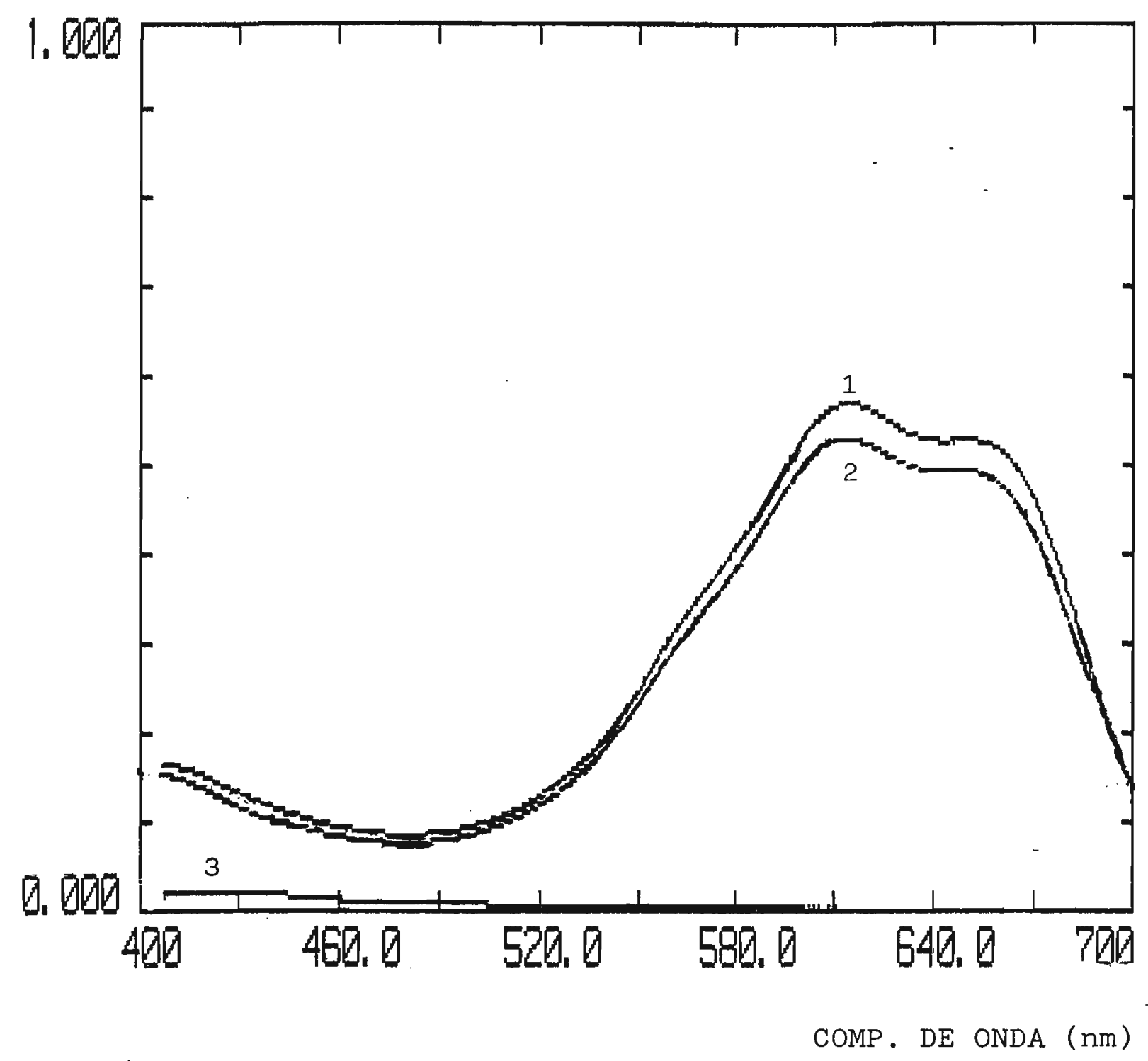

Figura 6.19 - Comparação entre os espectros de absorção no visí vel:

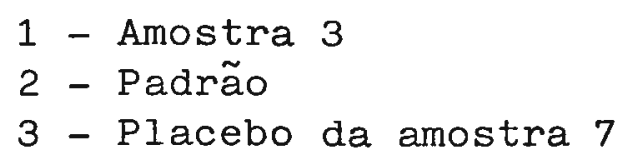


ABS

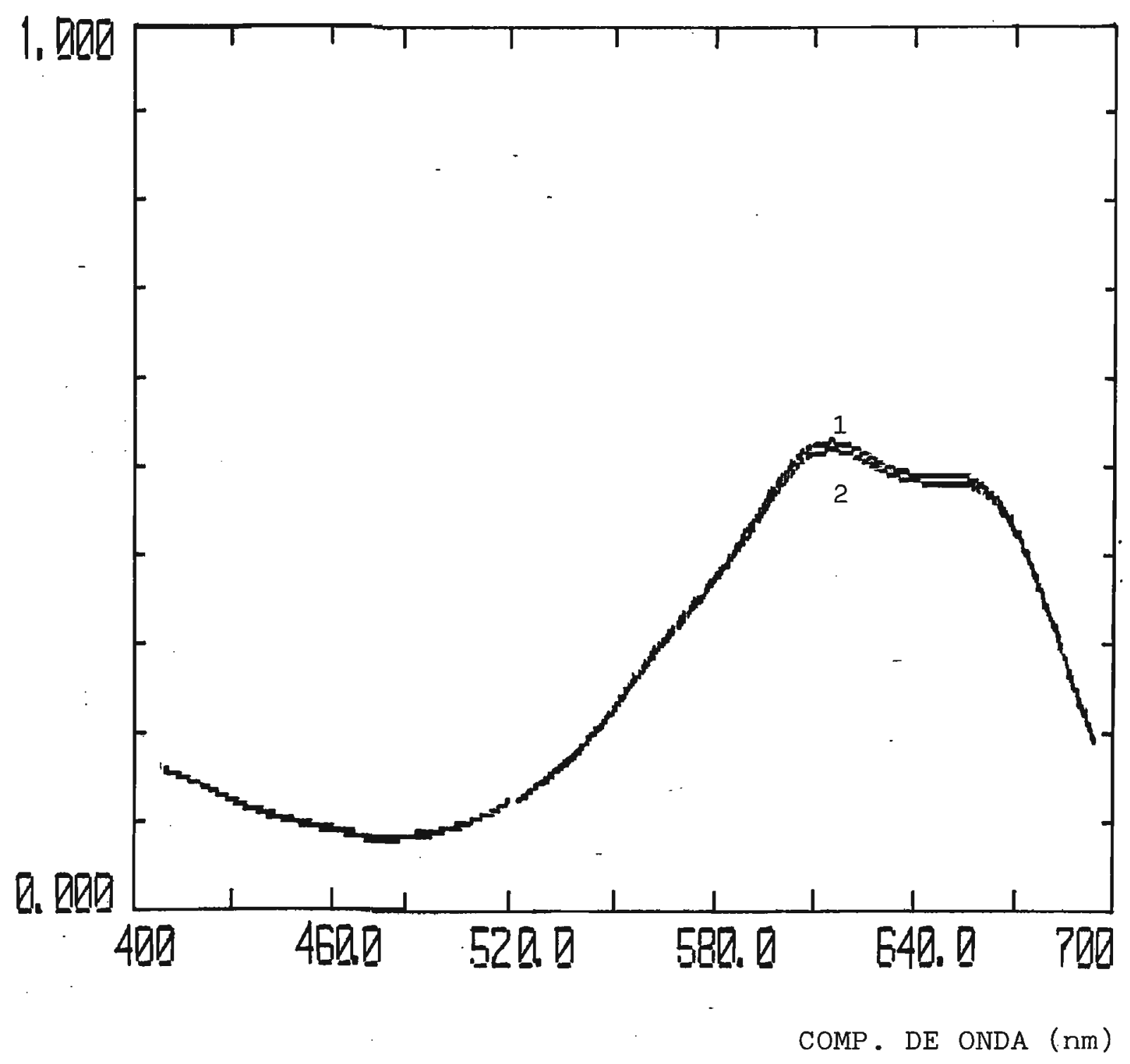

Figura 6.20 - Comparação entre os espectros de absorção no visível:

$$
\begin{aligned}
& 1 \text { - Padrão } \\
& 2 \text { - Amostra } 4
\end{aligned}
$$


Tábela 6.10 - Resultados obtidos na determinação do teor de cloridrato de ranitidina em amostras comerciais e simuladas, utilizando-se o método espectrofotométrico no visível.

\begin{tabular}{cccc}
\hline $\begin{array}{c}\text { Amostra } \\
\text { no }\end{array}$ & $\begin{array}{l}\text { Valor rotulado de } \\
\text { cloridrato de ra- } \\
\text { nitidina }\end{array}$ & $\begin{array}{l}\text { Valor encontrado } \\
\text { de cloridrato de } \\
\text { ranitidina* }\end{array}$ & $\begin{array}{c}\text { Teor } \\
\text { percentual } \\
(\%)\end{array}$ \\
\hline 1 & 150, oOmg/comp. & $143,67 \mathrm{mg} / \mathrm{comp}$. & 95,78 \\
2 & 50, OOmg/5mL & $43,34 \mathrm{mg} / 5 \mathrm{~mL}$ & 86,69 \\
3 & 56, OOmg/ $2 \mathrm{~mL}$ & $56,15 \mathrm{mg} / 2 \mathrm{~mL}$ & 100,27 \\
4 & $167,40 \mathrm{mg} / \mathrm{comp}$. & $164,12 \mathrm{mg} / \mathrm{comp}$. & 98,04 \\
5 & $150,00 \mathrm{mg} / \mathrm{comp}$. & $150,51 \mathrm{mg} / \mathrm{comp}$. & 100,34 \\
6 & $50,00 \mathrm{mg} / 5 \mathrm{~mL}$ & $50,29 \mathrm{mg} / 5 \mathrm{~mL}$ & 100,58 \\
7 & $56,00 \mathrm{mg} / 2 \mathrm{~mL}$ & $56,24 \mathrm{mg} / 2 \mathrm{~mL}$ & 100,42
\end{tabular}

* Média de dez determinações.

Tabela 6.11 - Resultados estatísticos obtidos na determinação do teor de cloridrato de ranitidina em amostras comer ciais e simuladas.

\begin{tabular}{ccc}
\hline $\begin{array}{c}\text { Amostra } \\
n=\end{array}$ & $\begin{array}{l}\text { Coeficiente de } \\
\text { variaçõo }(\%)\end{array}$ & $\begin{array}{l}\text { Intervalo de confiança- } \\
\text { da média }\end{array}$ \\
\hline 1 & 0,72 & $95,78 \pm 0,49$ \\
2 & 0,53 & $86,69 \pm 0,33$ \\
3 & 0,61 & $100,27 \pm 0,44$ \\
4 & 0,59 & $98,04 \pm 0,42$ \\
5 & 0,57 & $100,34 \pm 0,41$ \\
6 & 0,43 & $100,58 \pm 0,31$ \\
7 & 0,56 & $100,42 \pm 0,40$ \\
\hline
\end{tabular}


Tabela 6.12 - Resultados do teste de recuperação realizado nas amostras comerciais e simuladas, utilizando-se o método espectrofotométrico no visível.

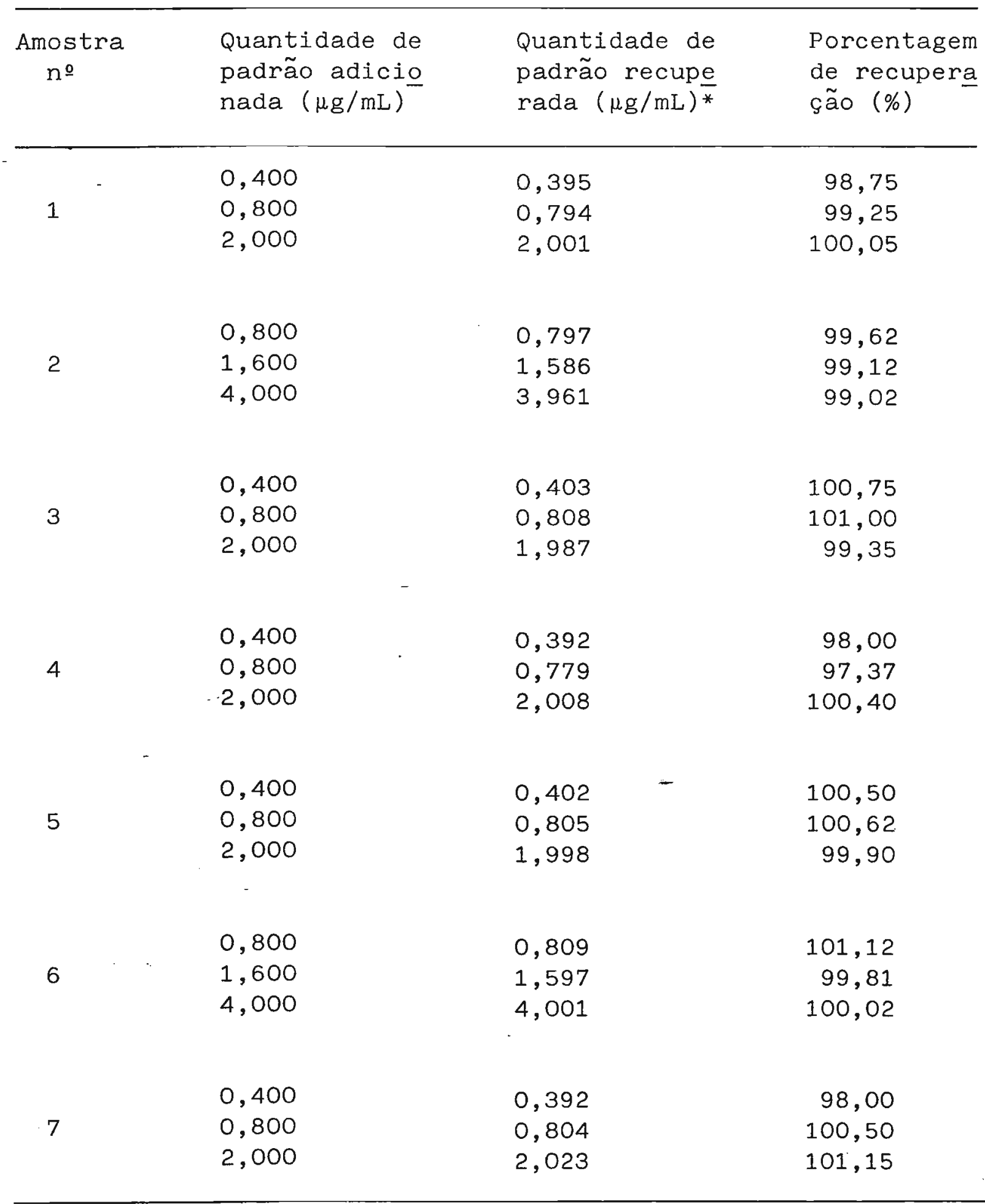

* Média de duas determinações. 
7 - ANÁlise estatística dos RESUltados

\section{1 - CÁlCULO DA RETA DE CALIBRAÇÃO}

Com os dados experimentais obtidos, foram calculadas e cons truídas as retas de calibração, aplicando-se o método dos mínimos quadrados $(14,66)$.

A seguir, apresenta-se o roteiro utilizado para o cálculo da reta de calibração, empregando-se os resultados obtidos na padronização do método espectrofotométrico no visível:

\begin{tabular}{|c|c|c|c|c|}
\hline $\begin{array}{c}\text { Concentração } \\
(\mu \mathrm{g} / \mathrm{mL}) \\
\mathrm{X}\end{array}$ & Absorbân & $x^{2}$ & $\mathrm{Y}^{2}$ & $X Y$ \\
\hline 1,44 & 0,2041 & 2,0736 & 0,04165681 & 0,293904 \\
\hline 1,92 & 0,2723 & 3,6864 & 0,07414729 & 0,522816 \\
\hline 2,40 & 0,3409 & 5,7600 & 0,11621281 & 0,818160 \\
\hline 2,88 & 0,4117 & 8,2944 & 0,16949689 & 1,185696 \\
\hline 3,36 & 0,4687 & 11,2896 & 0,21967969 & 1,574832 \\
\hline 3,84 & 0,5465 & 14,7456 & 0,29866225 & 2,098560 \\
\hline 4,32 & 0,6104 & 18,6624 & 0,37258816 & 2,636928 \\
\hline 4,80 & 0,6798 & 23,0400 & 0,46212804 & 3,263040 \\
\hline 5,28 & 0,7467 & 27,8784 & 0,55756089 & 3,942576 \\
\hline 5,76 & 0,8084 & 33,1776 & 0,65351056 & 4,656384 \\
\hline$\Sigma X=$ & $\Sigma Y=$ & $\Sigma X^{2}=$ & $\Sigma Y^{2}=$ & $\Sigma X Y=$ \\
\hline 36,0 & 5,0895 & 148,608 & 2,96564339 & 20,992896 \\
\hline
\end{tabular}


Calcularam-se os seguintes valores:

$$
\begin{aligned}
& \Sigma X \cdot \Sigma Y=36,0 \cdot 5,0895=183,222 \\
& (\Sigma X)^{2}=(36,0)^{2}=1296,0 \\
& (\Sigma Y)^{2}=(5,0895)^{2}=25,90301025
\end{aligned}
$$

Equação da reta de calibração: $Y=a+b X$

$$
\text { onde } \begin{aligned}
\mathrm{Y} & =\text { Absorbância } \\
\mathrm{X} & =\text { Concentração } \\
\mathrm{a} & =\text { Intersecção da reta } \\
\mathrm{b} & =\text { Inclinação da reta }
\end{aligned}
$$

1) Cálculo do valor de $\underline{b}$ :

Este valor foi calculado pela expressão:

$\mathrm{b}=\frac{\mathrm{n} \Sigma \mathrm{XY}-\Sigma \mathrm{X} \Sigma \mathrm{Y}}{\mathrm{n} \Sigma \mathrm{X}^{2}-(\Sigma \mathrm{X})^{2}}$

onde $\underline{\mathrm{n}}$ é o número de pontos da reta de calibração.

Assim,

$$
\mathrm{b}=\frac{(10 \cdot 20,992896)-183,222}{(10 \cdot 148,608)-1296,0}=0,140503788 \cong 0,1405
$$

2) Cálculo do valor de a :

Foi calculado pela expressão:

$$
a=\bar{Y}-b \bar{X}
$$


Sabendo-se que $\overline{\mathrm{Y}}=\Sigma \underline{Y} \cdot \because \underline{5,0895}=0,50895$

n

10

$$
\text { e } \quad \overline{\mathrm{X}}=\underbrace{\Sigma \underline{\mathrm{X}}}_{\mathrm{n}} \cdot \frac{36,0}{10}=3,60
$$

então,

$$
\begin{aligned}
& a=0,50895-(0,140503788 \cdot 3,60) \\
& a=0,003136363 \cong 0,0031
\end{aligned}
$$

3) Cálculo do erro padrão da estimativa ( $\underline{\mathrm{Se}})$ :

$$
\operatorname{Se}=\sqrt{\frac{\Sigma(Y-\hat{Y})^{2}}{n-2}}
$$

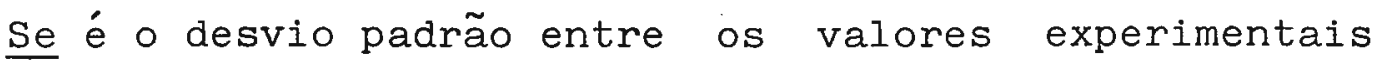
(Y) e os valores calculados a partir da equação da reta $(\hat{Y})$. 0 termo $\mathrm{n}$ - 2 no denominador está relacionado aos dois graus de $1 \underline{i}$ berdade perdidos quando os parâmetros $\underline{b}$ e a foram especificados. o termo $(Y-\hat{Y})^{2}$ no numerador foi obtido como mostrado a seguir:

\begin{tabular}{ccccc}
\hline $\begin{array}{c}\text { Conc. } \\
(\mu \mathrm{g} / \mathrm{mL}) \\
\mathrm{X}\end{array}$ & $\begin{array}{c}\text { Abs } \\
\mathrm{Y}\end{array}$ & $\hat{\mathrm{Y}}=\mathrm{a}+\mathrm{bX}$ & $\mathrm{Y}-\hat{\mathrm{Y}}$ & $(\mathrm{Y}-\hat{\mathrm{Y}})^{2}$ \\
\hline 1,44 & 0,2041 & 0,205461818 & $-0,001361818$ & 0,000001855 \\
1,92 & 0,2723 & 0,272903633 & $-0,000603636$ & 0,000000364 \\
2,40 & 0,3409 & 0,340345454 & 0,000554546 & 0,000000308 \\
2,88 & 0,4117 & 0,407787272 & 0,003912728 & 0,000015309 \\
3,36 & 0,4687 & 0,475229091 & $-0,006529091$ & 0,000042629 \\
3,84 & 0,5465 & 0,542670909 & 0,003829091 & 0,000014662 \\
4,32 & 0,6104 & 0,610112727 & 0,000287273 & 0,000000083 \\
4,80 & 0,6798 & 0,677554545 & 0,002245455 & 0,000005042 \\
5,28 & 0,7467 & 0,744996364 & 0,001703636 & 0,000002902 \\
5,76 & 0,8084 & 0,812438182 & $-0,004038182$ & 0,000016307 \\
\hline & & & & $\Sigma=0,000099461$
\end{tabular}


Assim,

Se $=\sqrt{\frac{0,000099461}{8}}=0,003525993$

Erro padrão relativo da estimativa ( $\left.\mathrm{Se}_{\mathrm{r}}\right)$ :

$$
\begin{aligned}
& \operatorname{Se}_{r}=100 \cdot \frac{\mathrm{Se}}{\bar{Y}} \\
& \mathrm{Se}_{r}=0,692797479 \cong 0,69 \%
\end{aligned}
$$

4) Teste de significância de a :

Aplicou-se o teste "t".

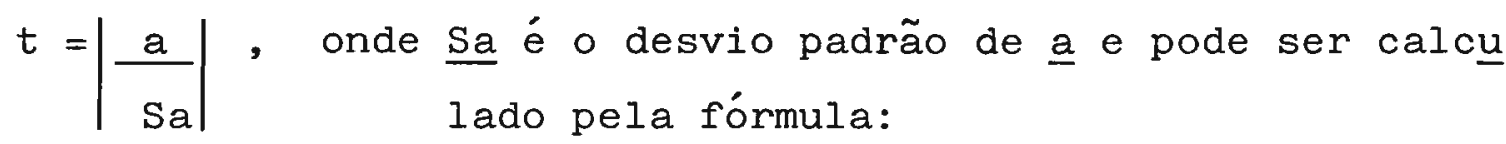

$\mathrm{Sa}=\mathrm{Se} \cdot \sqrt{\frac{\Sigma \mathrm{X}^{2}}{\mathrm{n} \Sigma \mathrm{X}^{2}-(\Sigma \mathrm{X})^{2}}}$

$\mathrm{Sa}=0,00311770$

Então:

$t=\left|\frac{0,003136363}{0,003117700}\right|=1,005986144 \cong 1,0060$

O valor tabelado para o nível de significância 5\% e 8 graus de liberdade é $t=2,306$. Como o valor calculado de $t$ é menor que - valor tabelado, conclui-se que a intersecção não é significantemente diferente de zero; logo a reta passa pela origem. 


$$
\begin{aligned}
& \text { Com } \underline{a}=\text { zero, calculou-se } b^{\prime}: \\
& b^{\prime}=\frac{\Sigma X Y}{\Sigma X^{2}}=\frac{20,992896}{148,608}=0,141263566 \cong 0,1413
\end{aligned}
$$

E a equação da reta fica:

$$
Y=0,1413 X
$$

5) Cálculo do coeficiente de correlação $(r)$ :

o coeficiente de correlação está relacionado à linearidade da reta e foi calculado pela expressão:

$$
\begin{aligned}
& r=\frac{\Sigma X X}{\sqrt{\left(\Sigma X^{2}\right) \cdot\left(\Sigma Y^{2}\right)}} \\
& r=\frac{20,992896}{20,99329257}=0,99998111 \simeq 0,9999
\end{aligned}
$$

7.2 - CÁLCULO DO COEFICIENTE DE VARIAÇÃO - DETERMINAÇÃO DO CLORIDRATO DE RANITIDINA EM MEDICAMENTOS

o coeficiente de variação está relacionado com a precisão (88).

Para cada amostra de medicamento foi calculado o coeficien te de variação, com base nos resultados de dez análises.

o roteiro mostrado a seguir é referente aos cálculos efetu ados para a amostra 1 , quando analisada pelo método espectrofoto métrico no ultravioleta. 


\begin{tabular}{cc}
$\begin{array}{c}\text { Amostra } \\
(n \circ)\end{array}$ & $\begin{array}{c}\text { Absorbância } \\
(313 \mathrm{~nm})\end{array}$ \\
\hline 1 & 0,4978 \\
2 & 0,4998 \\
3 & 0,5032 \\
4 & 0,5024 \\
5 & 0,5026 \\
6 & 0,4999 \\
7 & 0,5031 \\
8 & 0,5015 \\
9 & 0,5006 \\
10 & 0,5031 \\
\hline
\end{tabular}

Média $=0,5014$

\begin{tabular}{cr}
\hline $\begin{array}{c}\text { Padrão } \\
(\mathrm{n} 0)\end{array}$ & $\begin{array}{c}\text { Absorbância } \\
(313 \mathrm{~nm})\end{array}$ \\
\hline 1 & 0,5203 \\
3 & 0,5217 \\
& 0,5227 \\
\hline
\end{tabular}

A concentração $(x)$ de cloridrato de ranitidina referente a cada ensaio foi calculada pela expressão:

Aa $\times C p=x \mu g$ de cloridrato de ranitidina $/ \mathrm{mL}$ Ap 
onde $\mathrm{Aa}=\mathrm{Absorbância} \mathrm{da} \mathrm{amostra}$

$\mathrm{Ap}=\mathrm{Absorb} a \hat{n} c i a$ do padrão

$\mathrm{Cp}=$ Concentração do padrão

O valor percentual de cloridrato de ranitidina na amostra $(x \%)$ é calculado por:

$$
x \%=\frac{x \cdot 100}{x t}
$$

onde xt é a concentração teórica de cloridrato de ranitị dina em $\mu \mathrm{g} / \mathrm{mL}$.

Assim, para os dez valores obtidos nas análises, tem-se:

\begin{tabular}{cccc}
\hline $\begin{array}{c}\text { Amostra } \\
(\mathrm{n} \circ)\end{array}$ & Concentração & & \\
\hline 1 & $(\mathrm{x} \%)$ & $(\mathrm{x}-\overline{\mathrm{x}})$ & $(\mathrm{x}-\overline{\mathrm{x}})^{2}$ \\
2 & 95,01 & $-0,68$ & 0,4624 \\
3 & 95,39 & $-0,30$ & 0,0900 \\
4 & 96,04 & 0,35 & 0,1225 \\
5 & 95,88 & 0,19 & 0,0361 \\
6 & 95,92 & 0,23 & 0,0529 \\
7 & 95,41 & $-0,28$ & 0,0784 \\
8 & 96,02 & 0,33 & 0,1089 \\
9 & 95,71 & 0,02 & 0,0004 \\
10 & 95,54 & $-0,15$ & 0,0225 \\
\hline & 96,02 & 0,33 & 0,1089 \\
\hline
\end{tabular}


Cálculo da variância:

$$
\begin{aligned}
& V=\frac{\Sigma(x-\bar{x})^{2}}{n-1}, \text { onde } \underline{n}=10 \\
& V=\frac{1,0830}{9}=0,120333333
\end{aligned}
$$

Cálculo do desvio padrão (S):

$$
\begin{aligned}
& \mathrm{S}=\sqrt{\mathrm{V}} \\
& \mathrm{S}=0,346890953
\end{aligned}
$$

o coeficiente de variação (CV) foi calculado pela expressão:

$$
\begin{aligned}
& \mathrm{CV}=\frac{100 \cdot \mathrm{S}}{\overline{\mathrm{x}}} \\
& \mathrm{CV}=0,362515365 \cong 0,36 \%
\end{aligned}
$$

o limite de confiança da média (LC) para $P=95 \%$, foi calculado:

$$
\mathrm{LC}=\overline{\mathrm{x}} \pm \mathrm{t} \cdot \mathrm{Sm}, \text { onde } \mathrm{t}=2,262 \text { para } 9 \text { graus de } 1 \mathrm{i}-
$$
berdade.

Sm é o desvio padrão da média e é calculado pela ex pressão:

$$
\begin{aligned}
& \mathrm{Sm}=\frac{\mathrm{S}}{\sqrt{\mathrm{n}}}, \text { sendo } \underline{\mathrm{n}}=10 \\
& \mathrm{Sm}=0,109696551
\end{aligned}
$$

Assim,

$$
\begin{aligned}
\mathrm{LC} & =95,69 \pm 0,248133598 \\
& =95,69 \pm 0,25
\end{aligned}
$$


7.3 - COMPARAÇÃO DA EXATIDÃO E PRECISÃO DOS MÉTODOS PROPOSTOS

Os testes de significância são amplamente utiliza dos na avaliação de resultados experimentais, servindo para verificar se a diferença entre dois resultados é significante ou se pode ser atribuída ao acaso (47).

Dentre eles, os mais importantes são o teste "t", usado para ve rificar a significância de uma média ou da diferença entre duas médias, e o teste "F", usado na comparação de duas variâncias (51).

A comparação da exatidão de dois métodos é feita pẹ 10 teste "t" $(47,50,51,81)$.

Este teste permite avaliar se as médias dos valores experimen tais, obtidas por dois métodos distintos, têm diferença signifi cante a determinado nível (probabilidade).

Sejam $\bar{x}_{1}$ e $\bar{x}_{2}$ as médias obtidas das análises de uma mesma amostra, através de dois métodos diferentes (método 1 e método 2).

o desvio padrão. (S), baseado em ambos os métodos, é obtido através da variância calculada para os mesmos:

$$
s^{2}=\frac{\left(n_{1}-1\right) s_{1}^{2}+\left(n_{2}-1\right) s_{2}^{2}}{n_{1}+n_{2}-2}
$$

onde $\mathrm{S}_{1}^{2}$ é a variância da amostra pelo método 1

$\mathrm{S}_{2}^{2}$ é a variância da amostra pelo método 2

$n_{1}$ é o número de determinações pelo método 1

$\mathrm{n}_{2}$ é o número de determinações pelo método 2 
o valor de $t$ é calculado pela expressão:

$$
t=\frac{\bar{x}_{1}-\bar{x}_{2}}{s \sqrt{\frac{1}{n_{1}}+n_{2}}}
$$

onde $t$ tem $n_{1}+n_{2}-2$ graus de liberdade.

Se o valor calculado para $t$ exceder o tabelado, considera-se que a diferença entre a exatidão dos dois métodos é significante, a determinado nível (probabilidade).

A comparação da precisão de dois métodos é efetuada com a aplicação do teste $F(47,51,81)$.

$\underline{F}$ é definido como a proporção entre as variâncias dos resultados obtidos, através de métodos diferentes, para uma mesma amostra:

$$
F=\frac{S_{1}^{2}}{s_{2}^{2}}, \text { sendo que } S_{1}^{2}>S_{2}^{2}
$$

$\mathrm{S}_{1}^{2}$ e $\mathrm{S}_{2}^{2}$ são as variâncias dos resultados obtidos pelo método 1 e 2 , respectivamente.

O valor de $\underline{F}$ está relacionado aos graus de liberdade de $\mathrm{S}_{1}^{2}$ e $\mathrm{S}_{2}^{2}$. Se o valor calculado exceder o valor tabelado, a cer to nivel de probabilidade, a diferença entre a precisão dos dois métodos é significante. 
A tabela 7.1 apresenta os parâmetros envolvidos nos cálculos efetuados na comparação dos métodos propostos neste trabalho.

A tabela 7.2 apresenta os valores de $\underline{t}$ calculados na comparação da exatidão dos dois métodos e a tabela 7.3 mostra os valores de $\underline{F}$ obtidos na comparação da precisão dos mesmos. 
Tabela 7.1 - Resultados obtidos na determinação do cloridrato de ranitidina em amostras comerciais e simuladas.

\begin{tabular}{|c|c|c|c|}
\hline $\begin{array}{c}\text { Amostra } \\
\text { no }\end{array}$ & & $\begin{array}{c}\text { Espectrofotometria no } \\
\text { ultravioleta }\end{array}$ & $\begin{array}{c}\text { Espetrofotometria no } \\
\text { visível }\end{array}$ \\
\hline \multirow{3}{*}{1} & $\bar{x}$ & 95,69 & 95,78 \\
\hline & $\mathrm{S}$ & 0,346890953 & 0,686844637 \\
\hline & $\mathrm{n}$ & 10 & 10 \\
\hline \multirow{3}{*}{2} & $\bar{x}$ & 88,88 & 86,69 \\
\hline & $\mathrm{S}$ & 0,454752680 & 0,459589189 \\
\hline & $\mathrm{n}$ & 10 & 10 \\
\hline \multirow{3}{*}{3} & $\overline{\mathrm{x}}$ & 101,15 & 100,27 \\
\hline & $\mathrm{S}$ & 0,240115713 & 0,615051940 \\
\hline & $\mathrm{n}$ & 10 & 10 \\
\hline \multirow{3}{*}{4} & $\bar{x}$ & 98,47 & 98,04 \\
\hline & $S$ & 0,701213234 & 0,582885542 \\
\hline & $\mathrm{n}$ & 10 & 10 \\
\hline \multirow{3}{*}{5} & $\bar{x}$ & 100,24 & 100,34 \\
\hline & $\mathbf{S}$ & 0,841143402 & 0,572518801 \\
\hline & $\mathrm{n}$ & 10 & 10 \\
\hline \multirow{3}{*}{6} & $\bar{x}$ & 100,02 & 100,58 \\
\hline & $\mathrm{S}$ & 0,234591844 & 0,432794537 \\
\hline & $\mathrm{n}$ & 10 & 10 \\
\hline \multirow{3}{*}{7} & $\bar{x}$ & 100,02 & 100,42 \\
\hline & $S$ & 0,202017601 & 0,55903687 \\
\hline & $\mathrm{n}$ & 10 & 10 \\
\hline
\end{tabular}

$\overline{\mathrm{x}}=$ Média dos valores experimentais em $\%$

$\mathrm{S}=$ Desvio padrão

$\mathrm{n}=$ Número de determinações 
Tabela 7.2 - Resultados obtidos na comparação da exatidão dos mé todos propostos

\begin{tabular}{cc}
\hline $\begin{array}{c}\text { Amostra } \\
n \cong\end{array}$ & $\begin{array}{c}\text { Valor calculado de } \\
\text { "t" }\end{array}$ \\
\hline 1 & $0,370^{*}$ \\
2 & 10,711 \\
3 & 4,215 \\
4 & $1,491^{*}$ \\
5 & $0,311^{*}$ \\
6 & 3,597 \\
7 & 2,129 \\
\hline
\end{tabular}

Valores da tabela $t$ de Student:

Para $\mathrm{P}=95 \%$ e 18 graus de liberdade, $\mathrm{t}=2,101$

*Valores não significativos.

Tabela 7.3 - Resultados obtidos na comparação da precisão dos mé todos propostos

\begin{tabular}{lc}
\hline $\begin{array}{c}\text { Amostra } \\
n^{2}-\end{array}$ & $\begin{array}{c}\text { Valor calculado de } \\
\text { "F" }\end{array}$ \\
\hline 1 & $3,920^{*}$ \\
2 & $1,021^{*}$ \\
3 & 6,561 \\
4 & $1,447^{*}$ \\
5 & $2,158^{*}$ \\
6 & $3,403^{*}$ \\
7 & 7,657 \\
\hline
\end{tabular}

Valores da tabela "F":

Para $\mathrm{P}=95 \%$ e $9 / 9$ graus de liberdade, $F=4,026$

*Valores não significativos. 
8 - DISCUSSÃO

Os medicamentos contendo cloridrato de ranitidina são bastante comercializados no Brasil. Assim, tornou-se necessário colocar à disposição dos laboratórios de controle de qualidade de medicamentos uma metodologia mais barata e accessivel que a CLAE, para a determinação deste fármaco.

No presente trabalho foram padronizados dois métodos espectrofotométricos, um no ultravioleta e outro no visivel.

\section{1 - ESPECTROFOTOMETRIA NO ULTRAVIOLETA}

O espectro de absorção do cloridrato de ranitidina no ultravioleta, em água destilada (figura 6.1), mostra dois máximos de absorção, um a $227 \mathrm{~nm}$ e outro a $313 \mathrm{~nm}$.

A absorção máxima no menor comprimento de onda é devida, princi palmente, ao cromóforo furano dissubstituído, com uma contribui ção do grupo nitro eteno diamino, que tem sua principal absorção no maior comprimento de onda (11).

8.1.1 - ESCOLHA DO COMPRIMENTO DE ONDA DE LEITURA

Um composto intermediário que se forma em um dos processos de sintese da ranitidina exibe máximos de absorção a 230 e $235 \mathrm{~nm}$, com um ombro a $288 \mathrm{~nm}$. Assim, a medida da absorção a $313 \mathrm{~nm}$ é mais conveniente para determinação quantitativa da ranitidina, mesmo na presença desta impureza (35).

Testes realizados no presente trabalho mostraram que a $313 \mathrm{~nm}$, a absorção do cloridrato de ranitidina diminuiu com maior intensidade que a $227 \mathrm{~nm}$, depois que este foi submetido a altas temperaturas $(105 \circ \mathrm{C})$ durante determinado tempo (72 h). Isto 
sugere que a determinação do fármaco a $313 \mathrm{~nm}$, em medicamentos que se encontram em processo de degradação influenciada por temperatura, forneceria resultados (em cloridrato de ranitidina íntegro) mais confiáveis que a $227 \mathrm{~nm}$.

O cloridrato de ranitidina tem sua estabilidade dimi nuída em $\mathrm{pH}$ ácido (33).

Testes realizados no presente trabalho mostraram que à medida em que se diminuiu $\circ \mathrm{pH}$ de uma solução de cloridrato de ranitidina contendo $12 \mu \mathrm{g} / \mathrm{mL}$, a absorção a $313 \mathrm{~nm}$ diminuiu com maior intensidade que a $227 \mathrm{~nm}$. Isto sugere que a determinação do fármaco em preparações líquidas seria mais adequada a $313 \mathrm{~nm}$, já que a degradação do mesmo, influenciada pelo abaixamento do $\mathrm{pH}$, não poderia ser bem evidenciada a $227 \mathrm{~nm}$.

Por todas as razões mostradas anteriormente, o método espectrofotométrico no ultravioleta foi padronizado a $313 \mathrm{~nm}$.

\subsection{2 - PESQUISA DE INTERFERÊNCIA A PARTIR DOS EXCIPIENTES}

No presente trabalho estudou-se o comportamento no ultravioleta, de alguns medicamentos comercializados no Brasil, contendo cloridrato de ranitidina. Verificou-se que em todas as formulações estudadas, o fármaco poderia ser determinado, em água destilada e sem interferência dos excipientes, a $313 \mathrm{~nm}$.

As figuras $6.4,6.5,6.7$ e 6.9 mostram a semelhança entre os espectros das amostras comerciais e do padrão, na região em que o método foi padronizado.

As figuras $6.4,6.6,6.8$ e 6.9 mostram os espectros das amostras simuladas, comparados com as respectivas .. amostras 
comerciais, confirmando-se a semelhança entre elas (do ponto de vista da análise espectral no UV).

As figuras $6.4,6.7$ e 6.9 mostram os espectros dos placebos das amostras simuladas, sugerindo que os outros componentes (excipientes, veículos) que possuem absorção no ultravioleta, não interferem no método proposto. Os espectros das figu ras 6.7 e 6.9 são devidos, principalmente, ao álcool benzílico e ao fenol, respectivamente.

8.2 - ESPECTROFOTOMETRIA NO VISÍVEL

$\mathrm{Na}$ revisão da literatura foram encontrados vários métodos de determinação do cloridrato de ranitidina através da espectrofotometria no visível com a utilização de diversos reativos. O cloridrato-da hidrazona da 3-metil-2-benzotiazolinona (MBTH) foi o reativo que causou maior interesse, devido principal mente, às suas vastas possibilidades de aplicação na determina ção de um elevado número de fármacos, já que reage, sob condicõés diferentes, com vários grupamentos químicos, o que lhe confere em muitos casos, características de seletividade.

O método espectrofotométrico no visível foi padronizado a partir do trabalho de RAO e equipe (61), desenvolvido para determinação de ranitidina em comprimidos. Apesar da reação proposta na citada referência reunir as princịpais características pretendidas no presente trabalho, foram necessárias algumas modificações importantes.

Na reação original, são utilizados $1,0 \mathrm{~mL}$ de solução dè cloridrato de ranitidina $(200 \mu \mathrm{g} / \mathrm{mL}), 2,0 \mathrm{~mL}$ de solução de MBTH a $0,20 \%$ e $5,0 \mathrm{~mL}$ de solução de cloreto férrico a $0,20 \%$, pre paradas em $\mathrm{HCl} 0,1 \underline{\mathrm{M}}$. 
No presente trabalho, foram utilizados $5,0 \mathrm{~mL}$ de solução de cloridrato de ranitidina $(40 \mu \mathrm{g} / \mathrm{mL})$, para que fosse pos sível a construção da curva de RIngbon e reta de calibração. Os volumes das soluções de $\mathrm{MBTH}$ e de cloreto férrico foram mantidos como no método original.

8.2.1 - DETERMINAÇÃO DÁ CONCENTRAÇÃO ÓTIMA DE MBTH E CLORETO FÉR RICO

Para se verificar se a concentração das soluções de MBTH e cloreto férrico utilizadas no trabalho original era a ideal, foram testadas várias concentrações do primeiro reagente, mantendo-se fixas as concentrações do segundo.

Como pode ser observado na figura 6.10 , quando se utilizou cloreto férrico a 0,20\%, à medida em que foram variadas as concentrações de MBTH, as absorbâncias do produto colorido aumentaram, obtendo-se leitura máxima quando a concentração deste reagente era de $0,20 \%$. A partir desta concentração, as absorbâncias foram diminuindo progressivamente, o que sugere que o exces so de $\overline{M B T H}$ vai inibindo a reação, nesta concentração de cloreto férrico.

Assim, tornou-se necessário estudar o comportamento da reação com outras concentrações de cloreto férrico.

Com cloreto férrico a $0,30 \%$ foram obtidos resultados um pouco melhores que os anteriores, com estabilização da absorbância nas concentrações de 0,30 e $0,35 \%$ de MBTH.

Porém, os melhores resultados foram obtidos com cloreto férrico a $0,40 \%$, quando foi obtida estabilização da absorbância nas concentrações de 0,30, 0,35 e 0,40\% de $\mathrm{MBTH}$, sugerindo maior estabi lidade da reação.

Com cloreto férrico a 0,50 e 1,00\%, além de não se obter estabilização da absorbância como aquela obtida a 0,40\%, foi observado 
um aumento da mesma, à medida em que foram aumentadas as concentrações de MBTH.

Assim, foram definidas as concentrções de $0,35 \%$ para a solução de MBTH e de $0,40 \%$ para a solução de cloreto férrico, consideradas ideais para a padronização do método.

\subsection{2 - INFLUÊNCIA DO SOLVENTE}

Alguns trabalhos mostram que as reações envolvendo o MBTH e o ion férrico ocorrem em meio aquoso ácido (clorídrico) $(19,20,21,22,54,55)$, em metanol $(72,73,74,77,79)$ ou em água destilada (73).

A água destilada foi testada como solvente no presen te trabalho ; porém, não foram fornecidos resultados satisfatórios para a determinação quantitativa do cloridrato de ranitidina, como pode ser visto na tabela 6.6 .

o metanol não foi testado como solvente, já que solu ções de ácido clorídrico forneceram bons resultados. Como pode ser observado na tabela 6.6, a absorbância aumentou à medida em que foi aumentada a concentração de ácido clorídrico. A utilização do ácido clorídrico 0,01 M seria mais econômica; pó rém, optou-se pela utilização da solução de ácido clorídrico 0,1

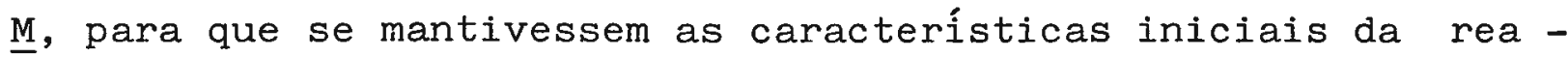
ção, quando da determinação da concentração ótima de MBTH e cloreto férrico.

\subsection{3 - TEMPO NECESSÁRIO PARA A ESTABIIIZAÇÃO DA REAÇÃO}

Na determinação do tempo necessário para a estabilização da reação (figura 6.11), verificou-se um crescimento inicí al rápido da absorbância (de zero a nove minutos, aproximadamen- 
te), tornando-se mais lento, com tendência à estabilização a par tir dos 27 minutos aproximadamente, sugerindo que este deve ser - tempo mínimo para que a reação seja completada.

\section{2 .4 - INFLUÊNCIA DA ADIÇÃO DE ÁGUA}

Algumas reações envolvendo o MBTH e o cloreto férrico foram eretuadas com adição de água destilada, trinta minutos após a adição deste oxidante.. $(22,54,55)$.

Com o objetivo de se estudar o comportamento da reação após adição de água, completou-se o volume indicado com este solvente, logo após a adição de cloreto férrico e 30 minutos após a adição do mesmo. Pelos resultados obtidos (tabela 6.7), ve rifica-se interrupção do crescimento da absorbância, independen te do tempo em que foi adicionada, sugerindo que a água inibe o desenvolvimento da reação.

Assim, a água deve ser utilizada para promover a estabilização da reação, decorridos trinta minutos da adição de cloreto férrico, fato que é necessário para que o método seja reprodutível e possa ser aplicado em determinações quantitativas. Convém lembrar que o tempo estabelecido para que a reação se complete seja respeitado igualmente, para cada determinação individual. Para isto, deve ser estabelecido um intervalo de tempo entre a adição do cloreto férrico nas amostras a serem analisadas, respeitandose o mesmo intervalo para a adição da água (para completar o volume de cada amostra).

\subsection{5 - TEMPO DE ESTABILIDADE DA REAÇÃO}

Nas condições estabelecidas para o método a reação manteve-se estável após adição de água destilada, durante 120 mí nutos, no mínimo (figura 6.12); porém, é importante ressaltar 
que é necessário utilizar reagentes de preparo recente, para que este fato possa ser reproduzido.

\subsection{6 - ESPECTRO DE ABSORÇÃO DO PRODUTO COLORIDO FORMADO}

Após a verificação dos principais fatores que afetam a reação e o estabelecimento das melhores condições para o desen volvimento e estabilidade da mesma, traçou-se 0 espectro de absorção do produto formado (de cor turquesa) - o qual possui absorção máxima a $615 \mathrm{~nm}$ - contra o branco (de cor amarela proveniente da solução de cloreto férrico e que possui absorção em região de comprimento de onda menor) (figura 6.14).

8.2.7 - MECANISMO E RELAÇÃO ESTEQUIOMÉTRICA

A maioria dos trabalhos que utilizaram MBTH na análí se de medicamentos propõe mecanismos para as reações envolvidas através de analogias com outras reações anteriormente estudadas $(18,19,20,21,22,27,62,64,73,75,76,77)$. Não existem, na maioria dos casos, estudos mais profundos sobre a estrutura química dos produtos originados destas reaçós ou sobre as eta pas envolvidas.

Não existe na literatura consultada nenhuma referên cia a mecanismos que envolvam MBTH e grupamentos químicos idênti cos àqueles existentes na molécula do cloridrato de ranitidina, nas condições da reação proposta. Por este motivo, pela impossi bilidade de se desenvolver os métodos analíticos necessários a este propósito, e além de não ser objetivo deste trabalho, não será feita qualquer sugestão de mecanismo para a reação. Entretanto, dẹterminou-se a relação estequiométrica entre o cloridrato de ranitidina e o MBTH, ○ que poderá ser de grande auxílio a futuros estudos dos mecanismos envolvidos na reação. Segun do o método utilizado nesta determinação, obteve-se medida de

* A reação se processa à temperatura ambiente. 
absorbância máxima para aquela solução proveniente de $2,0 \mathrm{~mL}$ de cloridrato de ranitidina e $8,0 \mathrm{~mL}$ de MBTH. Como as soluções possuíam a mesma concentração molar, a reação tem relação estequiométrica igual a 1:4 (cloridrato de ranitidina : MBTH)(fig.6.13).

\subsection{8 - PESQUISA DE INTERFERÊNCIA A PARTIR DOS EXCIPIENTES}

O método espectrofotométrico no visível demonstrou ser aplicável à quantificação do cloridrato de ranitidina nas amostras analisadas, sob o aspecto da ausência de interferência a partir de excipientes/veículos das mesmas.

As figuras $6.17,6.18,6.19$ e 6.20 mostram que as a mostras, quando submetidas à reação, fornecem espectros de absor ção com as mesmas características do padrão, independente da observação visual (semelhança de cor entre padrão e amostras 1 , 3, 4, 5, 6 e 7, e ligeira diferença entre padrão e amostra 2). Para o estudo dos interferentes foram submetidos à reação os placebos das amostras simuladas. Foram obtidas respostas visuais totalmente diferentes daquelas observadas para o padrão e para as amostras; as cores obtidas foram muito próximas à cor do branco da reação. Isto é confirmado pelas figuras 6.17 , 6.18 e 6.19 , as quais mostram que os espectros de absorção a par tir dos placebos têm seus máximos em regiões diferentes da região de absorção máxima do padrão e das amostras. A insignifican te coloração desenvolvida pelos placebos não interferiu na deter minação do teor de cloridrato de ranitidina nas amostras analisa das.

Foram realizados testes com cada componente das amo tras simuladas, com o objetivo de estudar sua resposta ao méto do. Nenhum excipiente do comprimido reagiu com o MBTH, nas condi cões propostas. Outros excipientes normalmente utilizados na for mulação de comprimidos (como éxplosol, talco, metil e etilcelulo se) foram testados e não interferiram no método pro- 
posto. O mesmo foi observado para os componentes das formulações injetáveis; nestas, os conservantes foram objeto de maiores estu dos. Para o álcool benzílico nenhuma reação com o MBTH foi encontrada na literatura consultada.

Produtos coloridos foram obtidos da reação de vários fenóis e o MBTH, em presença de sulfato cérico amoniacal e meio ácido (sulfúrico). A maioria dos fenóis reagiu nestas condições, independente do tipo e posição do grupo substituinte pre sente, apesar da presença de um grupo eletronegativo na posição para ter dificultado o desenvolvimento de coloração. A reta de calibração foi obtida na faixa de concentração de 6 a $25 \mu \mathrm{g}$ de fenol/mL, aproximadamente (84).

Sulfato de terbutalina e sulfato de orciprenalina fo ram determinados em comprimidos, injetáveis e xarope, através da reação com MBTH a $0,25 \%$ e cloreto férrico a $1 \%$, em meio ácido (cloridrico). o produto colorido obtido foi medido a $478 \mathrm{~nm}$ e o mecanismo da reação foi atribuído aos grupamentos fenólicos exis tentes nas moléculas destes fármacos. A concentração de leitura foi $8 \mathrm{\mu g} / \mathrm{mL},(22)$.

No presente trabalho foi pesquisada a interferência do fenol adicionado como conservante da amostra 7 , na concentração de leitura da mesma $(0,5 \mu \mathrm{g}$ de fenol/mL). Nas condições propostas pelo método, esta concentração de fenol forneceu cor muito próxima à do branco da reação e não interferiu na determinação do cloridrato de ranitidina.

8.3 - CURVAS DE RINGBOM E RETAS DE CALIBRAÇÃO

As curvas de Ringbon obtidas pelos dois métodos pro postos forneceram os intervalos de concentração em que a lei de Beer foi obedecida e com os quais foram construidas as retas de calibração. Como pode ser visto nas figuras 6.2 e 6.3 o método 
espectrofotométrico no ultravioleta possui linearidade entre con centração e absorbância na faixa de 5,0 a $18,0 \mu \mathrm{g} / \mathrm{mL}$. O método espectrofotométrico no visível possui linearidade entre concentração e absorbância na faixa de 1,44 a $5,76 \mu \mathrm{g} / \mathrm{mL}$ (figu $\operatorname{ras} 6.15$ e 6.16 ).

Como pode ser observado, o método espectrofotométrico no visível apresentou maior sensibilidade que o método espectrofotométrico no ultravioleta.

8.4 - APLICAÇÃO DOS MÉTODOS NA DETERMINAÇÃO DO TEOR DE CLORIDRATO DE RANITIDINA A AMOSTRAS COMERCIAIS E SIMULADAS

O coeficiente de variação (tabelas 6.4 e 6.11), rela cionado à precisão dos resultados obtidos experimentalmente sob as condições estabelecidas $(85,88)$, foi calculado para cada amostra, empregando-se os resultados de dez determinações.

Os testes de recuperação, relacionados à exatidão dos valores obtidos (85), foram efetuados segundo a recomendação da "Association of Official Analytical Chemists" (AOAC) (2). Os resultados obtidos nos testes de recuperação(tabelas 6.5 e 6.12) foram satisfatórios.

Os limites estabelecidos pela Farmacopéia Americana XXII para o teor de ranitidina em comprimidos e injetáveis são, no mínimo $90 \%$ e no máximo $110 \%$ do valor rotulado ( 85 ). Os resul tados obtidos através dos dois métodos propostos no presente trabalho foram satisfatórios para as amostras analisadas, com exceção da amọtra 2 (tabelas 6.3 e 6.10).

8.5 - COMPARAÇÃO DA EXATIDÃO E PRECISÃO DOS DOIS MÉTODOS

Pela forma em que foi realizada a análise estatísti- 
ca, não se pode afirmar que um método é mais exato ou mais preci so que o outro, apenas se eles diferem significantemente ou não, em determinado nível (P).

A um nível de significância $\mathrm{P}=95 \%$, a comparação da exatidão dos dois métodos (tabela 7.2) mostrou que os métodos não diferem significantemente para as amostras 1, 4 e 5. As outras amostras, cujos resultados mostraram diferenças significantes ao nível con siderado não o são a níveis mais elevados de significância; porém a amostra 2 apresentou uma diferença de 2,19\% entre as médias obtidas pelos dois métodos, fornecendo um alto valor de $t$; Esta amostra apresenta evidentes sinais de degradação e a forte coloração apresentada fez com que houvesse ligeira diferença na comparação visual com o padrão, apesar de não se verificar diferença entre os espectros (figura 6.18). Por este motivo, a aplicação do método espectrofotométrico no visível pode ser considerado menos adequado que o método ultravioleta, para esta amostra em particular, nas condições de conservação da mesma.

$\mathrm{Na}$ comparação da precisão dos métodos propostos (tabela 7.3) pode-se observar que os métodos diferem significante mente (para $\mathrm{P}=95 \%$ ) apenas para as amostras 3 e 7 ; porém, a ní veis mais elevados, estes valores deixam de ser significantes. $\mathrm{Na}$ tabela 7.1 pode ser verificado que os desvios (S) são maiores para o método espectrofotométrico no visível (para as amostras $1,2,3,6 \mathrm{e} \mathrm{7)}$; isto pode ser atribuido ao fato da precisão diminuir com o decréscimo da concentração (43), já que a faixa de linearidade deste método compreende menores valores que o método espectrofotométrico no ultravioleta.

Quando analisados em conjunto os resultados mostram que os dois métodos são compatíveis quanto à exatidão e precisão para as amostras que se encontram em bom estado de conservação.

Pretendia-se fazer a comparação entre os dois métodos propostos e o método oficial da Farmacopéia Americana XXII, 
mas isto não foi possivel por falta de condições técnicas. 
9 - CONCLUSÕES

Pelos dados experimentais obtidos e nas condições em que foi realizado o trabalho, pode-se concluir que:

1 - o cloridrato de ranitidina pode ser determinado quantitativa mente por Espectrofotometria no ultravioleta, no intervalo de concentração: de 5,0 a $18,0 \mu \mathrm{g} / \mathrm{mL}$.

2 - O cloridrato de ranitidina pode ser determinado quantitativa mente por Espectrofotometria no visível, pela reação com o clorí drato da hidrazona da 3-metil-2-benzotiazolinona (MBTH) a 0,35\% em $\mathrm{HCl} 0,1 \underline{\mathrm{M}}$ e cloreto férrico a $0,40 \% \mathrm{em} \mathrm{HCl} 0,1 \underline{\mathrm{M}}$, no intervalo de concentração de 1,44 a $5,76 \mu \mathrm{g} / \mathrm{mL}$.

3 - Os métodos propostos podem ser empregados na análise quantitativa do cloridrato de ranitidina em medicamentos comercializados no Brasil.

4 - Os testes de recuperação efetuados apresentaram resultados que comprovaram a eficiência dos métodos utilizados.

5 - Os medicamentos testados não apresentaram interferência de excipientes em nenhum dos métodos propostos.

6 - Os métodos espectrofotométricos propostos para a determina ção do cloridrato de ranitidina em medicamentos podem ser utilizados como uma alternativa econômica, rápida e simples.

$\overline{7}$ - Os resultados da análise comparativa da exatidão e precisão dos dois métodos foram compativeis para todas as amostras que se encontravam em bom estado de conservação. 
10 - PERSPECTIVAS DE TRABALHOS FUTUROS

O desenvolvimento de metodologia analítica para determinação do cloridrato de ranitidina em medicamentos, princi palmente voltada para estudos de estabilidade do fármaco, consti tue área de grande importância, dado o número de fatores que influenciam na estabilidade do mesmo, como luz, temperatura e pH, por exemplo.

De outro lado, o cloridrato da hidrazona da 3-metil2-benzotiazolinona (MBTH) é um reagente que oferece um amplo espectro de aplicações na determinação de fármacos em medicamentos.

Geralmente os métodos espectrofotométricos desenvolvidos com este reagente, são rápidos e de fácil execução. Devido ao fato de suas reações fornecerem produtos coloridos diferentes frente a oxidantes distintos, os métodos desenvolvidos com a uti lização de MBTH, possuem, em muitos casos, características de seletividade, o que possibilitará sua aplicação na análise de fárma cos em associações farmacêuticas. 


\section{REFERÊNCIAS BIBLIOGRÁFICAS*}

1 - ABU ZUHRI, A.Z.; HANNOUN, M.; AL KHALIL, S.; HASNA, H. - Po larographic assay of ranitidine drugs in pharmaceutical formulation. Anal. Lett., New York, 21(10): 1845-53,1988.

2 - ASSOCIATION OFFICIAL ANALYTICAL CHEMISTS. Official methods of analysis, 15.ed., Arlington, 1990. v.1, p.xxii.

3 - ATKOSAR, Z.\& TUNCEL, M. - The potentiometric determination of ranitidine hydrochloride. Acta Pharm. Turc., Istanbul, $31(4): 139-42,1989$.

4 - BEALIEU, N.; LACROIX, P.M.; SEAR, R.W.; LOVERING, E.G. High-performance liquid chromatographic methods for the determination of ranitidine and related substances in raw materials and tablets. J. Pharm. Sci., Washington, 77(10): $889-92,1988$.

5 - BESTHORN, E. - Über derivate des benzthiazols. Ber. Dtsch. Chem. Ges., Berlin, 43: 1519-26, 1910.

6 - BULLOK, L.; PARKS, R.B.; LAMPASONA, V.; MULLINS, R.E. - Sta bility of ranitidine hydrochloride and amino acids in parenteral nutrient solutions. Am. J. Hosp. Pharm. , Washington, $\underline{42}$ : $2683-7,1985$.

* De acordo com a norma NB66/78 preconizada pela ASSOCIAÇÃO BRA SILEIRA DE NORMAS TÉCNICAS (ABNT). As abreviaturas dos títu los dos periódicos seguem o CHEMICAL ABSTRACTS SERVICE SOURCE INDEX (CASSI) 1990. 
7 - CANO, S.M.; MONTORO, J.B.; PASTOR, C.; POU, L.; SABIN, P. Stability of ranitidine hydrochloride in total nutrient admixtures. Am. J. Hosp. Pharm., Washington, 45(5): 11002,1988 .

8 - CAREY, P.F.; MARTIN, L.E.; EVANS, M.B. - High - performance liquid chromatographic methods for the determination of ranitidine and its metabolites in biological fluids. Chromatographia, Braunschweig, 19: 200-5, 1984.

9 - CAREY, P.F.; MARTIN, L.E.; OWEN, P.E. - Determination of ranitidine and its metabolites in human urine by reversed -phase ion-pair high-performance liquid chromatography. J. Chromatogr., Amsterdam, 225: 161-8, 1981.

10 - ChATTARAJ, S.C.; DAS, S.K.; GUPTA, B.K. - Spectrophotometric determination of ranitidine hydrochloride. Indian Drugs, $\underline{26}(7): 365-7,1989$. Apud: Chem. Abstr., Columbus, 111: $140640 u, 1989$.

11 - CHORLETON, T.J.; HUNT, J.H.; KLINKERT, G.; MARTIN-SMITH, M.Spectroscopic studies on ranitidine - Its structure and the influence of temperature and $\mathrm{pH}$. J. Chem. Soc. Perkin Trans II. London, 11: 1761-6, 1984.

12 - DALY, M.J. - Ranitidine - A novel $\mathrm{H}_{2}$-receptor antagonist. Med. Actual., Barcelona, 18(11): 615-9, 1982.

13 - DAS GUPTA, V. - Quantitation of ranitidine hydrochloride in tablets and injection using high-performance liquid chromatography. Drug Dev. Ind. Pharm., 14(12): 1647-55, 1988. Apud: Chem. Abstr., Columbus, 109: 197287x, 1988. 
14 - DAVIS, R.B.; THOMPSON, J.E.; PARDUE, H.L. - Characteristics of statistical parameters used to interpret least-square results. Clin. Chem., Winston Salem, 24(4): 611-20, 1978.

15 - DELGADO ZAMARREÑO, M.; HERNANDEZ MENDEZ, J.; SANCHEZ PEREZ, A. - Electrochemical study and polarographic determina tion of ranitidine. Anäl. Chim. Acta, Amsterdam, 176: $27 \underline{9}$ 84,1985 .

16 - DICIONÁRIo de especialidades farmacêuticas. 20.ed., Rio de $\downarrow$ Janeiro, Publicações Científicas, 1991/1992.

17 - DRUGS evaluations annual 1991. Milwaukee, American Medical \& Association, 1990. p.763-75.

18 - EL-KOMMOS, M.E. - Spectrophotometric determination of do butamine hydrochloride using 3-methylbenzothiazolin - 2one hydrazone. Analyst, London, 112(1): 101-3, 1987.

19 - EL-KOMMOS, M.E. \& EMARA, k.M. - Application of 3-methylbenzothiazolin-2-one hydrazone as a chromogenic reagent for the spectrophotometric determination of certain sulpha drugs. Analyst, London, $113(1): 133-7,1988$.

20 - EL-KOMMOS,M.E.\& EMARA, K.M. - Spectrophotometric determination of certain local anaesthetics using 3-methylbenzo thiazolin-2-one hydrazone. Analyst, London, 112(9): 125ㅡㅡ 6,1987 .

21 - EL-KOMMOS,M.E.\& EMARA, K.M. - Spectrophotometric determination of some phenothiazine drugs using 3-methylbenzothiazolin-2-one hydrazone. Analyst, London, 113(8): $126 \underline{7}$ $71,1988$. 
22 - EL-YASBI, F.A.; ABDEL-HAY, M.H.; KORANY, M.A. - Spectrophotometric, fluorometric and colorimetric determination of terbutaline sulphate and orciprenaline sulphate. Farmaco Ed. Prat., Pavia, $\underline{40}(2): 50-7,1985$.

23 - EMMANUEL, J. \& HALDANKAR, S.D. - A simple and sensitive spectrocolorimetric method for the estimation of ranitidine hydrochloride and its formulations. Indian Drugs, 26 (5): 249-50, 1989. Apud: Chem. Abstr., Columbus, 110: $179630 \mathrm{v}, 1989$.

24 - GALANTE, L.J.; STEWART, J.T.; WARREN, F.W.; EDGAR, " J.W. ; HUFF, A.J. - Stability of ranitidine hydrochloride with eight medications in intravenous admixtures. Am. J.Hosp. Pharm., Washington, 47 (7): 1606-10,1990.

25 - GALANTE, L.J.; STEWART, J.T.; WARREN, F.W.; JOHNSON, S.M. ; DUNCAN, R. - Stability of ranitidine hydrochloride at di lute concentration in intravenous infusion fluids at room temperature. Am. J. Hosp. Pharm., Washington, 47(7): $1580-4,1990$.

26 - GANGULY, S.K. \& GHOSH, K. - Estimation of ranitidine in pharmaceutical preparations. East. Pharm., New Delhi, 29 $(348): 151,1986$.

27 - GEETA, N. \& BAGGI, T.R. - A new spectrophotometric method for the determination of free salicylic acid in aspirin and its formulations based on oxidative coupling of $3-$ methylbenzthiazolinone-2-hydrazone with salicylic acid. Microchem. J., New York, 38(2): 236-40, 1988. 
28 - GOODMAN, L.S. \& GILMAN, A. - The pharmacological basis of $\phi$ therapeutics. 8 ed. New York, Pergamon Press, 1990. p. 897-902.

29 - GRANT, S.M.; LANGTRY, H.D.; BROGDEN, R.N. - Ranitidine. An updated review of its pharmacodynamic and pharmacokine tic properties and therapeutic use in peptic ulcer disease and other allied diseases. Drugs, Auckland, 37(6) : $801-70,1989$.

30 - GUISO, G.; FRACASSO, C.; CACCIA, S.; ABBIATI, A. - Determination of ranitidine in rat plasma and brain by high-per formance liquid chromatography. J. Chromatogr., Amsterdam, 413: $363-9,1987$.

31 - GUVENER, B. - Spectrophotometric determination method of ranitidine hydrochloride. Acta Pharm. Turc., Istanbul, 28 (1): $35-7,1986$.

32 - HARAGUCHI, T. \& KOROLKOVAS, A. - Doseamento do cloridrato de ranitidina com ácido perclórico em meio não aquoso. 中ev. Farm. Bioquim. Univ. S. Paulo, São Paulo, $\underline{21}(2)$ : $146-50,1985$.

33 - HAYWOOD, P.A.; MARTIN-SMITH, M.; CHORLETON, T.J.; EVANS, M. B. - Isolation and identification of the hidrolytic deg2 radation products of ranitidine hydrochloride. J. Chem. Soc. Perkin Trans. I, London, (5): 951-4, 1987.

34 - HOHNJEC, M.; KUFTINEC, J.; MALNAR, M.; SKREBLIN, M.; KAJFEZ, F.; NAGL, A.; BLAZEVIC, N. - Ranitidine. Anal. Profiles Drug Subst., New York, 15: 533-61, 1986. 
35 - HOHNJEC, M.; RENDIC, S.; ALEBIC-KOLBAH, T.; KAJFEZ , F. ; BEAZEVIC, N.; KUFTINEC,J. - Physical and spectroscopic data of ranitidine. Acta Pharm. Iugosl., Zagreb, 31 : $131-42,1981$.

36 - JOB, P. - Recherches sur la formation de complexes mineraux en solution,et sur leur stabilité. Ann. Chim., Paris, 10 (9): 113-203, 1928.

37 - KAKA, J.S. - Rapid method for cimetidine and ranitidine de termination in human and rat plasma by HPLC. J. Liq. Chromatogr., 11(16): 3447-56, 1988. Apud: Chem. Abstr., Columbus, 110: 224885v, 1989 .

38 - KARNES, H.T.; OPONG-MENSAH, K.; FARTHING, D.; BEIGHTOL, L. : A. - Automated solid-phase extraction and high-perfor mance liquid chromatographic determination of ranitidine from urine, plasma and peritoneal dialysate. I. Chromatogr., Amsterdam, 422: 165-73, 1987.

39 - KOK, W.T.; HALYAX, J.J.; VOOGT, W.H.; BRINKMAN, U. A. T.; FREI, R. W. - Detection of thioethers of pharmaceutical importance by liquid chromatography with on-line generated bromine. Anal. Chem., Washington, 57(13): 2580-3, 1985.

40 - LAMPASONA, V.; MULLINS, R.E.; PARKS, R.B. - Stability of ranitidine admixtures frozen and refrigerated in mini* bags. Am. J. Hosp. Pharm., Washington, 43: 921-5, 1986.

41 - LANGMAN, M.J.S. - Histamine $\mathrm{H}_{2}$ antagonists. Med. Actual.. Barcelona, 16(11): 393-402, 1980. 
42 - MARTIN, L.E.; OXFORD, J.; TANNER, R.J.N. - Use of hgh-per formance liquid chromatography-mass spectrometry for the study of metabolism of ranitidine in man. J.Chromatogr., Amsterdam, 251: 215-24, 1982.

43 - MARTIN-SMITH, M. \& RUDD, D.R. - The importance of proper validation of the analytical methods employed in the quality control of pharmaceuticals. Acta Pharm. Iugosl., Zagreb, $40(1-2): 7-19,1990$.

44 - MARTINDALE, W.H. - The extra pharmacopeia. 29.ed., London, \$ Pharmaceutical Press, 1989. p.1104-5.

$\$ 45$ - MERCK index - 11.ed., Rahway, 1989. p.1291.

46 - MIHALY, G.W.; DRUMMER, O.H.; MARSHALL, A.; SMALLWOOD, R.A.; LOUIS, W.J. - High-pressure liquid chromatographic deter mination of ranitidine, a new $\mathrm{H}_{2}$-receptor antagonist, in plasma and urine. J. Pharm. Sci., Washington, 69(10) : 1155-7, 1980 .

47 - MILLER, J.C. \& MILLER, J.N. - Statistics for analytical chemistry. 2.ed. Chilchester, Ellis Horwood, 1988. p.53$62,216-23$.

48 - MITSANA-PAPAZOGLOU, A.; DIAMANDIS, E.P.; HADJIIOANNOU,T.P.Ion-selective electrodes. for the $\mathrm{H}_{2}$-receptor antagonists cimetidine and ranitidine. J.Pharm. Sci., Washington, 76 (6) : 485-91, 1987 . 
49 - MULLERSMAN, G. \& DERENDORF, H. - Rapid analysis of ranitidi ne in biological fluids and determination of its erythrocyte partitioning. J. Chromatogr., Amsterdam, 381 : $385-91,1986$.

50 - NALIMOV, U.V. - The application of mathematical statistics to chemical analysis. Oxford, Pergamon Press, 1963. $\dot{p}$. $100-3$.

51 - OHLWEILER, O.A. - Química analítica quantitativa. Rio de Ja neiro, Livros Técnicos e Científicos, 1974. v.1, p. 265303.

52 - OZSOY, Y. \& GUVENER, B. - Spectrophotometric determination method of ranitidine hydrochloride in tablets. Acta Pharm. Turc., Istanbul, $\underline{29}(1): 13-6,1987$.

53 - PATEL, R.B.; GANDHI, T.P.; PATEL, U.C.; PATEL, S.K.;GILBERT, R.N. - Colorimetric estimation of ranitidine hydrochlori de in bulk and dosage form. Indian J. Pharm. Sci.,45(3): 130-1, 1983. Apud: Chem. Abstr., Columbus, 100: 91478j, 1984 .

54 - PAYS, M.; BOURDON, R.; BELJEAN, M. - Diazocopulation des amines et des heterocycles azotes a l'aide du reactif HMBT. Anal. Chim. Acta, Amsterdam, 47: 101-11, 1969.

55 - PAYS, M.; MALANGEAU, P.; BOURDON, R. - Dosage colorimétrique de divers aldéhydes en présence de l'hydrazone de la 3 méthylbenzothiazoline-2-one. Ann. Pharm. Fr., Paris, 24 (12) : 763-8, 1966 . 
56 - PRICE, B.J.; CLITHEROW, J.W.; BRADSHAW, J. - Pharmaceutical alkylfuran derivatives. Ger. Offen. 2, 734,070, 1978, 83 p. Apud: Chem. Abstr., Columbus, 88: 190580b, 1978.

57 - PRUEKSARITANONT, T.; SITTICHAI, N.; PRUEKSARITANONT, S . ; VONGSAROJ, R. - Simultaneous determination of ranitidine and its metabolites in human plasma and urine by high performance liquid chromatography. J. Chromatogr., Amsterdam, $\underline{490}(1): 175-85,1989$.

58 - RADULOVIC, D.; PECANAC, D.; KAPETANOVIC, M. - Spectrophotometric determination of ranitidine with bromocresol green and bromophenol blue. Arch. Farm., 40(3): 71-5, 1990. Apud: Chem. Abstr., Columbus, 114: 129233e, 1991.

59 - RAHMAN, A.; HOFFMAN, N. E.; RUSTUM, A.M. - Determination of ranitidine in plasma by high-performance liquid chro matography . J. Pharm. Biomed. Anal., Oxford, $7(6): 74 \underline{7}$ 53,1989 .

60 - RAO, E.V.; RAO, G.R:; RAO, P.I.; MURTY, S.S.N. -Colorimetric determination of ranitidine in tablets. East. Pharm., New Delhi, $30(354): 135-6,1987$.

61 - RAO, E.V.; RAO,P.J.; MURTY, S.S.N.; RAO, G.R. -Colorimetric determination of ranitidine in tablets. Indian J. Pharm. Sci., Bombay, $\underline{49}(4): 143-4,1987$.

62 - RAO, G.R.; AVADHANULU, A.B.; GIRIDHAR, R. - Spectrophoto metric determination of guaiphenesin in formulations using 3-methyl-2-benzothiazolinone hydrazone hydrochloride.East. Pharm., New Delhi, 31(367): 141-2, 1988. 
63 - RAO, G.R.; AVADHANULU, A.B.; VATSA, D.K. - Spectrophotometric estimation of ranitidine hydrochloride in its pharma ceutical dosage forms. Indian Drugs, 27(2): 135-6, 1989. Apud: Chem. Abstr., Columbus, 112: 42743f, 1990.

64 - RAO, G.R.; MURTY, S.S.N.; RAJU, I.R.K. - Spectrophotometric determination of sulphalene in dosage forms.East.Pharm., New Delhi, 32(381): 141-2, 1989.

65 - RAUT, K.N. \& SABNIS, S.D. - New spectrophotometric method for estimation of ranitidine hydrochloride. Indian J.

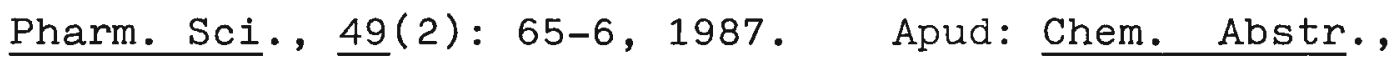
Columbus, 107: 161781y, 1987.

66 - REMINGTON'S pharmaceutical sciences. 18.ed. Easton, Mack, d 1990. p. 778-82, 104-37.

67 - RUSTUM, A.M. - Rapid and sensitive HPLC determination of ranitidine in plasma. Application to pharmacokinetics study. J. Liq. Chromatogr., 11(11): 2315-35, 1988. Apud: Chem. Abstr., Columbus, 110: 50631s, 1989.

68 - RUSTUM, A.M.; RAUHMAN, A.; HOFFMAN, N.E. - High-performance liquid chromatographic determination of ranitidine in d whole blood and plasma by using a short polymeric column. J. Chromatogr., Amsterdam, 421(2): 418-24, 1987.

69 - SADANA, G.S.; SANE, R.T.; OZARKAR, S.G.; SAPRE, D.S.; NAYAK, Y.G. - Extractive spectrophotometric method for the de termination of ranitidine hydrochloride from pharmaceu tical preparations. Indian Drugs, 23(10): 573-4, 1986. Apud: Chem. Abstr., Columbus, 106: 9478b, 1987. 
70 - SALEM, M.S.; GHARAIBEH, A.M.; ALKAYSI, H.N.; BADWAN, A High-performance liquid chromatographic analysis of ranitidine in plasma and urine. J. Clin. Pharm. Ther., 13 (5): 351-7, 1988. Apud: Chem. Abstr., Columbus, 110: $174 z, 1989$.

71 - SANKAR, P.S. \& REDDY, S.J. - Voltametric analysis of raniti dine. Indian J. Pharm. Sci., 51(6): 263-4, 1989. Apud : Chem. Abstr., Columbus, 113: 46377h, 1990.

72 - SASTRY, C.S.P. \& ARUNA, M. - Spectrophotometric determina tion of some anthelmintics and antiamoebic agents with 3- methyl-2-benzothiazolinone hydrazone hydrochloride . Pharmazie, Berlin, $\underline{43}(5): 361,1988$.

73 - SASTRY, C.S.P.; PRASAD, T.N.V.; SASTRY, B.S.; RAŌ, E.V. Spectrophotometric methods for the determination of some diuretics using 3-methyl-2-benzothiazolinone hydrazone • Analyst, London, $113(2): 255-8,1988$.

74 - SASTRY, C.S.P. \& RAO, A.R. - Spectrophotometric determina tion of some analgesic and anti-inflamatory agents with 3-methyl-2-benzothiazolinone hydrazone hydrochloride . Mikrochim. Acta, Wien, 1 $13-4): 237-44,1989$.

75 - SASTRY, C.S.P.; RAO, A.R.M.; PRASAD, T.N.V. - Spectrophotometric analysis of diclofenac sodium and piroxicam and their pharmaceutical preparations. Anal. Lett. New York, $\underline{20}(2): 349-59,1987$. 
76 - SASTRY, C.S.P.; SINGH, N.R.; REDDY, M.N. - New spectrophoto metric methods for the determination of Riboflavin. Analusis, Paris, 14 (7): $355-6,1986$.

77 - SASTRY, C.S.P.; SINGH, N.R.; REDDY, M.N.; SANKAR, D.G.-Spe trophotometric determination of menadione and menadione sodium bisulfite in pharmaceutical preparations. Int. J. Pharm., Amsterdam, 39(1-2): 137-40, 1987.

78 - SAWICK, E.; HAUSER, T.R.; STANLEY, T.W.; ELBERT, W. - The 3-methyl-2-benzothiazolone hydrazone test. Sensitive new methods for the detection, rapid estimation, and determi nation of aliphatic aldehydes. Anal. Chem., Washington, 33 $(1): 93-6,1961$.

79 - SAWICK, E.; STANLEY, T.W.; HAUSER, T.R.; ELBERT, W.; NOE, J.L. - Spot test detection and colorimetric determination of aromatic amines and imino heteroaromatic compounds with 3-methyl-2-benzothiazolone hidrazone. Anal. Chem., Washington, $33(6)$ : 722-5, 1961.

80 - SEgELMAN, A.B.; ADUSUMALLI, V.E.; SEGELMAN, F.H. -Automated liquid chromatographic determination of ranitidine in microliter samples of rat plasma. J. Chromatogr., Amsterdam, 535: 287-92, 1990 .

81 - SKOOG, D.A.; WEST, D.M.; HOLLER, F.J. - Fundamentals of analytical chemistry. 5. ed. New York, Saunders College, 1988. p.35-9. 
82 - SQUELLA, J.A.; ZUÑIGA, L.A.; LEMUS, I.; NUÑEZ-VERGARA,L.J. Simple determination of ranitidine in dosage forms by in -phase selective a.c. polarography. J. Assoc. Off. Anal. Chem., Washington, $\underline{71}(2): 388-90,1988$.

83 - STANCZAK, W. - Polarographic studies of some $\mathrm{H}_{2}$-blocking a-gents.I. Polarographic studies of ranitidine. Acta Pol. Pharm., Warsaw, 44(5): 446-51, 1987.

84 - UMEDA, M. - Color reaction of phenols. III. Color reaction of phenols with 3-methyl-2-benzothiazolinone hydrazone and cerium ammonium sulphate and its application to colorimetric determination of phenol. Yakugaku Zasshi, Tokyo, 83: 951-6, 1963.

85 - UNITED States pharmacopeia, 22. ed. Rockville, United States Pharmacopeial Convention, 1989. p. 1208-11, 17112 .

86 - WALKER, S- E. \& BAYLIFF, C.D. - Stability of ranitidine hydrochloride in total parenteral nutrient solution. Am. J. Hosp. Pharm., Washington, 42: 590-2, 1985.

87 - WILLIAMS, M.F.; HAK, L.J.; DUKES, G. - In vitro evaluation of the stability of ranitidine hydrochloride in total nu trient mixtures. Am. J. Hosp. Pharm., Washington, 47(7): 1574-9, 1990.

88 - WILSON, A.L. -The performance-characteristics of analytical methods - I. Talanta, London, 17: 21-9, 1970.

89 - ZANINI, A.C. \& OGA, S. - Farmacologia aplicada. 4. ed. São A Paulo, Atheneu, 1989. p.395-6. 


\section{RESUMO}

O cloridrato de ranitidina, um antagonista dos receptores $\mathrm{H}_{2}$ da histamina, foi determinado em comprimidos e inje táveis por espectrofotometria no ultravioleta, a 313nm, e por espectrofotometria no visivel, a $615 \mathrm{~nm}$, utilizando o cloridrato da hidrazona da 3-metil-2-benzotiazolinona (MBTH) a 0,35\% em $\mathrm{HCl} 0,1 \underline{\mathrm{M}}$ e cloreto férrico a $0,40 \%$ em $\mathrm{HCl} 0,1 \underline{\mathrm{M}}$, como reagentes de cor.

$\mathrm{Na}$ espectrofotometria no ultravioleta a lei de Beer foi obedecida no intervalo de concentração de 5,0 a $18,0 \mu \mathrm{g} / \mathrm{mL}$. Quatro amostras comerciais foram analisadas. Os coeficientes de variação foram $0,36 \%$ e $0,71 \%$ para comprimidos,e $0,51 \%$ e $0,24 \%$ para injetáveis. A média de recuperação foi $99,88 \%$.

Na espectrofotometria no visivel a lei de Beer foi obedecida no intervalo de concentração de 1,44 a 5,76. $\mu \mathrm{g} / \mathrm{mL}$. Os coeficientes de variação foram $0,72 \%$ e $0,59 \%$ para comprimidos,e $0,53 \%$ e $0,61 \%$ para injetáveis. A média de recuperação foi $99,39 \%$.

Os resultados foram comparados estatisticamente e foram compativeis para as amostras que se encontravam em bom es tado de conservação. 


\section{SUMMARY}

Ranitidine hydrochloride, a histamine $\mathrm{H}_{2}$-receptor an tagonist, was determined in tablets and injections by ultravio let spectrophotometry at $313 \mathrm{~nm}$, and visible spectrophotometry using as color reagent 0,35\% 3-methyl-2-benzothiazolinone hydrochloride in $\mathrm{HCl} 0, \underline{M}$ and $0,40 \%$ ferric chloride in $\mathrm{HCl} 0,1 \underline{M}$.

In ultraviolet spectrophotometry, Beer's law was obeyed in the range of concentration from 5,0 to $18,0 \mu \mathrm{g} / \mathrm{mL}$. Four commercially available were analyzed. The coefficients of variation were $0,36 \%$ and $0,71 \%$ for tablets, and $0,51 \%$ and $0,24 \%$ for injections. The recovery average was $99,88 \%$.

In visible spectrophotometry, Beer's law was obeyed in the range of concentration from 1,44 to $5,76 \mu \mathrm{g} / \mathrm{mL}$. The coefficients of variation were $0,72 \%$ and $0,59 \%$ for tablets, and $0,53 \%$ and $0,61 \%$ for injections. The recovery average was $99,39 \%$.

The results obtained by using the two methods were statistically compared and were compatible when samples were kept in good conditions of storage. 